\title{
RISCO DO DESENVOLVIMENTO E A LEGÍTIMA EXPECTATIVA DO CONSUMIDOR
}

Tese de Mestrado apresentada à Banca Examinadora do Departamento de Direito Civil da Faculdade de Direito da Universidade de São Paulo, como exigência parcial para a obtenção do título de Mestre em Direito, sob a orientação do Prof. Dr. Carlos Alberto Dabus Maluf.

FACULDADE DE DIREITO DA USP

SÃO PAULO

2010 
Banca Examinadora 


\section{RESUMO}

Os fenômenos da produção e distribuição de massa expõem, o público a riscos sempre mais graves que, de forma variada, são imputáveis à organização dos processos produtivos.

O objetivo principal deste estudo é a análise do comportamento dos consumadores e da responsabilidade do produtor na circulação dos produtos defeituosos. Porém, o defeito não era conhecido no momento da distribuição do produto; em verdade, não teria sido possível identificar o risco.

Entretanto, a responsabilidade do produtor deve ser excluída, porque se percebe uma revisão das regras tradicionais da responsabilidade civil, mas o consumidor não pode permanecer sem ressarcimento do dano.

A solução mais adequada deverá ser a criação de sistemas de garantias de modo a obter da união dos fabricantes do produto defeituoso e do próprio Estado.

É um dever que cada um se obriga a respeitar cada vez que de seus atos possa resultar aos outros perigos de danos.

Palavras-chave: Consumidor, Responsabilidade do produtor, Produto defeituoso, Direitos do consumidor 


\section{RIASSUNTO}

In fatti, i fenomeni di produzione e distribuizione di massa espongono, il pubblico a rischi sempre più gravi che, in vario modo, sono imputabili all'organizzazione dei fattori produttivi.

Lo scopo principale di questo studio è l'analisi del comportamento dei consumatori e della responsabilità del produttore nella circolazione di prodotti diffetosi. Però, il diffeto non era conosciuto nel momento della distribuizione del prodotto; in realtà, non sarebbe stato possibile preveder il rischio.

Pertanto, la responsabilità del produttore viene esclusa, perche si assiste ad una revisione delle regole tradicionale della responsabilità civile, ma il consumatore non può rimanere senza risarcimento del danno.

La soluzione più adeguata dovrà essere la creazione di sistemi di assicurazione in ordine da raggiungere l'unione dei fabbricanti del produtto diffetoso ed il proprio Stato.

È un dovere che ognuno è tenuto a rispettare ogni volta che dai suoi atti possa derivare ad altri pericolo di danni.

Parole chiave: Consumatori, Responsabilità da prodotti difettosi, Danno da prodotti difettosi, Diritti dei consumatori 


\section{SUMÁRIO}

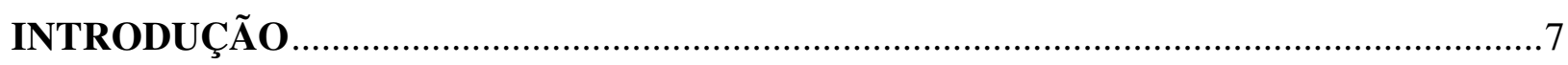

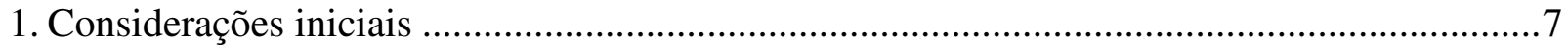

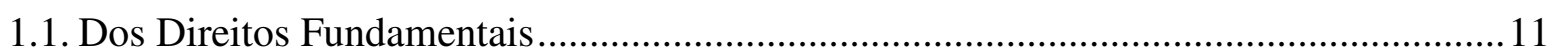

1.2. Da importância do estudo do risco do desenvolvimento ............................................ 14

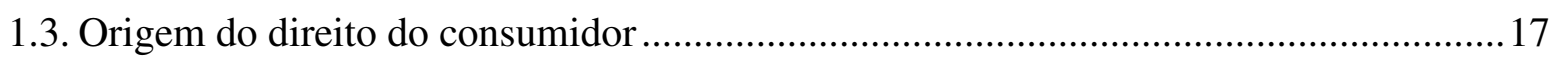

1.3.1. Início do desenvolvimento Industrial ........................................................... 17

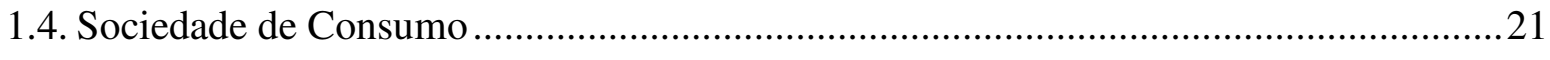

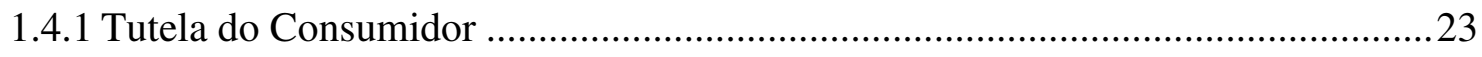

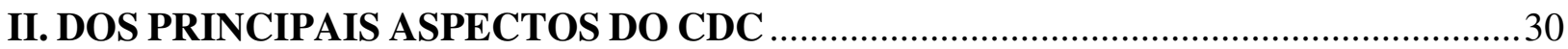

2. Dos principais aspectos do código de defesa do consumidor ............................................... 30

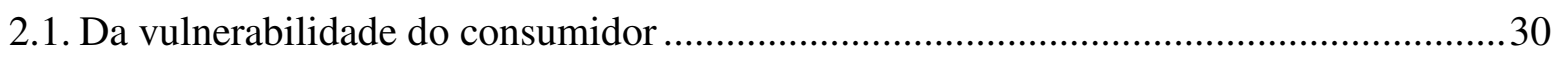

2.2. Da presença do Estado no poder econômico ................................................................ 33

2.2.1. Da evolução da responsabilidade do Estado...................................................... 37

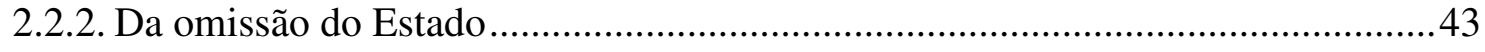

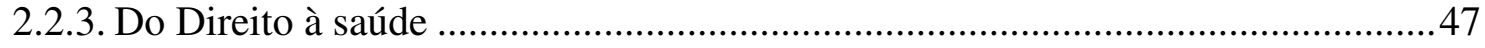

2.3. Da livre iniciativa e proteção do consumidor .............................................................50

2.3.1. Do conflito entre empresa e consumidor ......................................................52

III. DO CÓDIGO DE DEFESA DO CONSUMIDOR ........................................................56

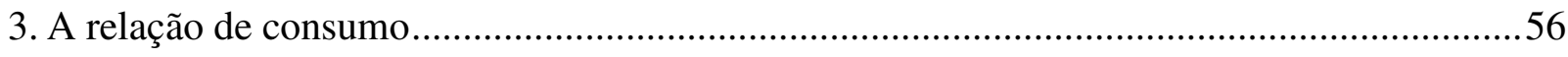

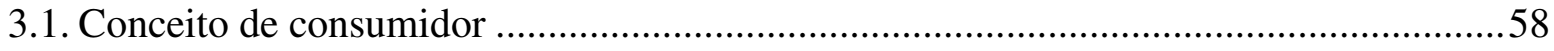

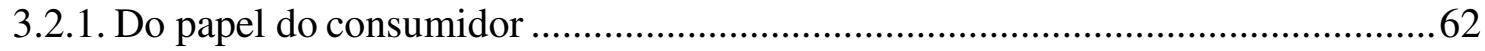

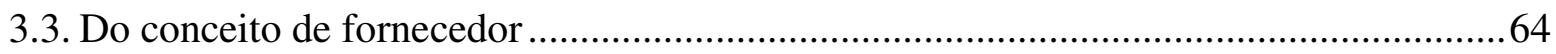

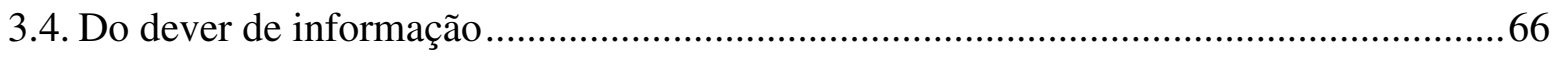

IV. DA RESPONSABILIDADE PELO FATO DO PRODUTO ........................................ 70

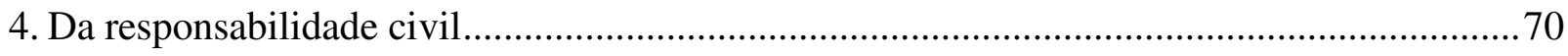

4.1. Da responsabilidade pelo fato do produto .................................................................. 74

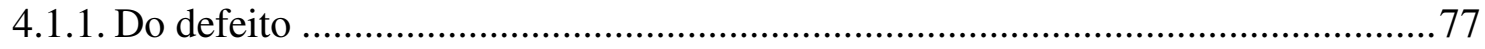

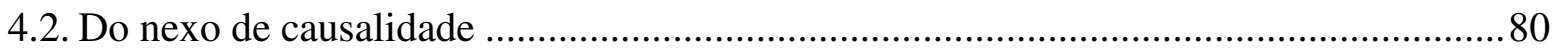


4.2.1. Da flexibilização do nexo de causalidade .......................................................... 85

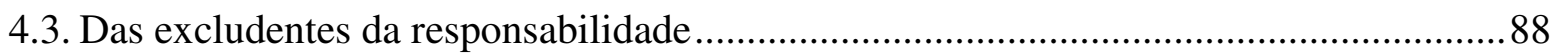

4.3.1. Das Excludentes de responsabilidade no âmbito do CDC .................................90

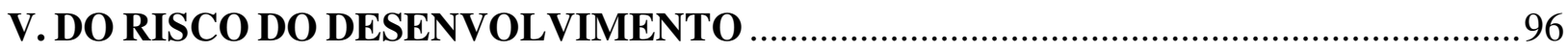

5. Do risco do desenvolvimento e legítima expectativa do consumidor ...................................96

5.1. Do risco do desenvolvimento e excludente de responsabilidade ................................. 103

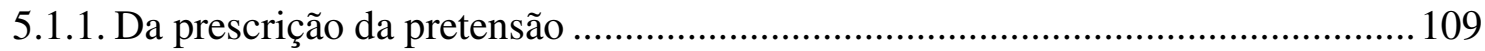

5.2. Do princípio da legalidade e a liberdade de escolha............................................... 111

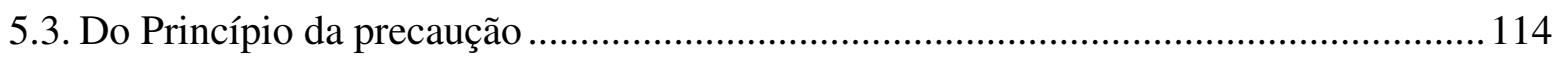

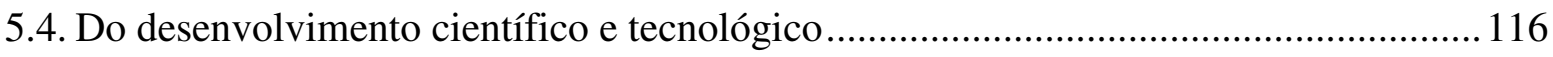

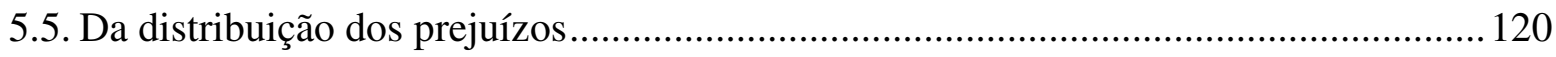

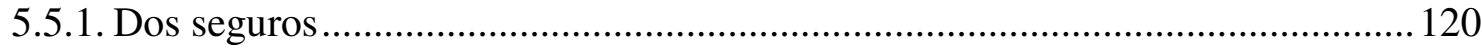

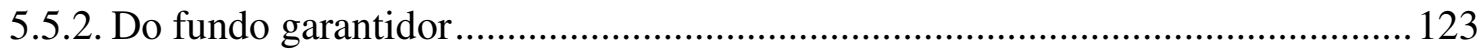

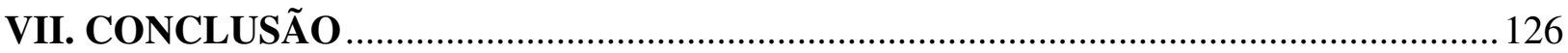

REFERÊNCIAS BIBLIOGRÁFICAS 


\section{INTRODUÇÃO}

\section{Considerações iniciais}

O ramo do direito do consumidor, que tem sua disciplina entre o direito privado e o direito público, visa proteger o consumidor, o sujeito de direito, em todas as relações jurídicas que envolvam o fornecedor ou o comerciante.

As normas de proteção ao consumidor têm forte conteúdo de direito público, pois garantem a tutela de direito fundamental previsto na Constituição Federal. De fato, são normas cogentes, de observância obrigatória e cumprimento coercitivo. O próprio Código de Defesa do Consumidor, em seu artigo $1^{\mathrm{o}}$, estabelece que são normas de ordem pública e interesse social. $^{2}$

O Estado assume o papel de interventor e protege o consumidor vulnerável, do que decorrem sua imperatividade e inderrogabilidade pela vontade das partes.

Devido ao seu caráter social, a ONU (Organização das Nações Unidas), em 1985, estabeleceu diretrizes para esta legislação e consolidou a ideia de que se trata de direito humano de nova geração (ou dimensão), direito social e econômico, direito de igualdade material do mais fraco nas suas relações privadas.

\footnotetext{
${ }^{1}$ Vale transcrever o artigo: “Art. $1^{\circ} \mathrm{O}$ presente Código estabelece normas de proteção e defesa do consumidor, de ordem pública e interesse social, nos termos dos arts. $5^{\circ}$, inc. XXXII, 170, inc. V, da Constituição Federal e art. 48 de suas Disposições Transitórias."

${ }^{2}$ Nesse sentido, o seguinte julgado: "Direito civil - Promessa de compra e venda - Extinção - Iniciativa do promissário comprador - Perda das parcelas pagas - Cláusula abusiva - Código de Defesa do Consumidor - Norma de ordem pública - Arts. 51, IV, e 53 - Derrogação da liberdade contratual - Redução Possibilidade - Recurso desacolhido. I - A jurisprudência deste Superior Tribunal de Justiça uniformizouse pela redução da parcela a ser retida pelo promitente vendedor, nos casos de desfazimento do contrato de promessa de compra e venda, por inadimplência do comprador. II - O caráter de norma pública atribuído ao Código de Defesa do Consumidor derroga a liberdade contratual para ajustá-la aos parâmetros da lei, impondo-se a redução da quantia a ser retida pela promitente vendedora a patamar razoável, ainda que a cláusula tenha sido celebrada de modo irretratável e irrevogável. III - O acórdão que aprecia todos os pontos suscitados e necessários ao deslinde da controvérsia não contraria o art. 535, CPC, não se podendo exigir do órgão julgador menção expressa a dispositivos legais se solucionou a demanda na conformidade do pedido. IV - A dessemelhança fática entre o acórdão impugnado e o aresto paradigma não caracteriza a divergência jurisprudencial hábil a instaurar a via do recurso especial. (STJ - 4 ${ }^{\mathrm{a}}$ T. - REsp 292942/MG rel. Min. Sálvio de Figueiredo Teixeira - j. 03.04.2001).

Em outro houve a declaração de competência absoluta no processo: "Conflito de competência Competência territorial - Foro de eleição - Cláusula abusiva. O juiz do foro escolhido em contrato de adesão pode declarar de ofício a nulidade da cláusula e declinar da sua competência para o juízo do foro do domicílio do réu. Prevalência da norma de ordem pública que define o consumidor como hipossuficiente e garante a sua defesa em juízo. Conflito conhecido e declarada a competência do suscintante. (STJ $-2^{\mathrm{a}}$ Seção - CComp 21540?MS - rel. Min. Ruy Rosado de Aguiar - j.27.5.1998).
} 
Em 1988, a Constituição Federal consagrou a proteção ao consumidor no rol de direitos fundamentais e, nos termos do inciso XXXII do artigo $5^{\circ}$, estabelece que o Estado promoverá a defesa do consumidor. Ao se reconhecer essa dimensão jurídico-objetiva dos direitos fundamentais, obriga o Estado a agir para a realização desses direitos, reveste-se a norma de ordem pública e de interesse social. ${ }^{3}$

Há que se admitir alcance diferenciado perante os direitos fundamentais; nessa perspectiva, percebe-se que as violações de tais direitos não provêm apenas do lado estatal, mas principalmente do lado privado, na medida em que o norte a ser perseguido é a preservação da dignidade humana, tendo como parâmetro as expectativas do homem médio que delineia os conceitos de direito, sendo esses conceitos decisivos para a transposição dos valores constitucionais para o direito privado.

Reconhece-se que mesmo não sendo direito oponível contra o Estado não se lhe retira o caráter jurídico de direito fundamental, na medida em que o objetivo do Estado é valorizar a própria pessoa. A incidência dos direitos fundamentais não é imune ao âmbito do direito privado.

Por outro lado, autores como Fabio Konder Comparato questionam se realmente criou-se direito fundamental ao estabelecer que o Estado promoverá, na forma da lei, a defesa do consumidor. ${ }^{4}$

\footnotetext{
${ }^{3}$ Marcelo Schenk Duque inclusive questiona o alcance da norma: "Após vinte anos de vigência da constituição, coloca-se a questão em torno do significado e alcance desse direito, o que aponta, invariavelmente, para a determinação de sua natureza e função."

E adiante acrescenta: "O reconhecimento do significado dos direitos fundamentais a partir do seu caráter objetivo legitima, portanto, a proteção do consumidor como um verdadeiro direito fundamental, corolário do entendimento de que zelar pela tradição dos direitos fundamentais por meio de seu desenvolvimento posterior é uma tarefa permanente. Assim, o simples fato de a proteção constitucional do consumidor não ser enquadrada como um típico direito de defesa, oponível contra o Estado, não lhe retira por si só, o caráter jurídico fundamental. Nessa perspectiva, a evolução e a consolidação da compreensão dos direitos fundamentais como elementos da ordem objetiva mostram-se apropriados para justificar a proteção constitucional do consumidor, à medida que valorizam a pessoa como fundamento do Estado e como razão de ser dos direitos fundamentais, e à medida que fundamentam a criação de construções doutrinárias capazes de transportar os efeitos dos direitos fundamentais para o âmbito privado, nos termos que seguem." DUQUE, Marcelo Schenk. A proteção do consumidor como dever de proteção estatal de hierarquia constitucional. Revista de Direito do Consumidor, São Paulo, n. 70, P. 143-146, jul./set. 2009.

${ }^{4}$ Em suas palavras: "Isto posto, o que se deve indagar, preliminarmente, é se a norma do art. $5^{\circ}$, XXXII, declarando que " o Estado promoverá, na forma da lei, a defesa do consumidor", cria, efetivamente, um direito fundamental.

Na vigência da $1^{a}$ Revisão da Constituição Portuguesa, os seus mais autorizados intérpretes consideravam que a declaração de que "os consumidores têm direito à formação e à informação, à proteção da saúde, da segurança e dos seus interesses econômicos e à reparação de danos" representava a criação de autênticos direitos fundamentais "fora do catálogo" (CANOTILHO, J. J. Gomes; MOREIRA, Vital. Constituição da República Portuguesa anotada. 2. ed. Coimbra, 1984. v. 1, p. 475).

Não me parece que o mesmo possa ser afirmado da disposição do art. $5^{\circ}$, XXXII de nossa Constituição. Não é apenas o fato de que, aí, não se fala expressamente em "direitos": o emprego desse termo não significa,
} 
Nos termos do artigo 170 da Constituição Federal, a defesa do consumidor é declarada como princípio geral da atividade econômica, indicando o modo pelo qual o constituinte entendeu as relações de consumo; o próprio consumidor, objeto dessa proteção constitucional, é considerado unicamente como agente econômico.

Com efeito, o objetivo de qualquer atividade econômica é o consumo de bens para satisfazer necessidades; nesse sentido, o consumidor não pode ser relegado a plano inferior no processo econômico.

Outro aspecto importante suscitado pela CF é o fato de que o consumidor foi considerado vulnerável, o que o fez, digno, dessa forma, de proteção diferenciada pelo Estado $^{5}$. Sem dúvida, dá uma visão de cunho social às relações de consumo e foi justamente nessa seara que o Código de Defesa do Consumidor consagrou o princípio da vulnerabilidade como fundamento. Identifica-se, assim, um elo entre o direito privado e o direito público, ou seja, entre o dever constitucional de proteção do consumidor e o CDC; garante-se ao particular recorrer ao Estado contra ação lesiva de outros particulares para assegurar os seus direitos fundamentais protegidos.

Nenhum país do mundo deveria proteger seus consumidores apenas com o modelo privado; o Estado deve ser o promotor da defesa do consumidor, proteção de sua pessoa e de seus interesses existenciais. Os ordenamentos jurídicos em geral traduzem-se

necessariamente que a norma criou autênticos direitos subjetivos. O que importa, na verdade, é saber se se está ou não diante de situações subjetivas em que alguém possa, efetivamente, exigir algo de outrem, ou seja, tenha uma pretensão (Anspruch), exercitável por meio de ação judicial ou procedimento administrativo. A pretensão, como demonstrou a recente doutrina alemã, é também elemento integrante do direito subjetivo público (cf. HENKE, Wilhelm. Das subjektive öffentliche Recht. Tübingen, 1968. p. 54 e ss.).

Para que isso se verificasse, seria preciso que todo consumidor fosse titular, contra o Estado (em que extensão subjetiva: toda e qualquer pessoa jurídica de direito público interno e, também, todas as entidades da chamada Administração Pública indireta?), de uma pretensão a uma prestação determinada. Ora, a proteção ao consumidor, referida genericamente no citado dispositivo de nossa Constituição, não pode ser considerada uma prestação pública determinada. Ademais, a referência à mediatização da lei parece indicar que nenhum dever estatal específico de proteção determinada ao consumidor existe, enquanto não declarado em lei." (COMPARATO, Fabio Konder. A proteção ao consumidor na Constituição brasileira de 1988. Revista de Direito Mercantil, Industrial, Econômico e Financeiro, São Paulo, v. 29, n. 80, p. 69, out./dez. 1990).

Adiante o mesmo autor complementa: “A defesa do consumidor é declarada, no art.170, como princípio geral da atividade econômica, o que já dá uma ideia precisa de como o constituinte brasileiro de 1988 entendeu as relações de consumo. O consumidor, objeto dessa proteção constitucional, é considerado unicamente como agente econômico." (Id. Ibid., p. 70).

${ }^{5}$ Ainda que tenha sido a proteção ao consumidor consagrada pela Constituição Federal em julgado apreciado pela Suprema Corte, não foi caracterizada a ofensa direta a dispositivos constitucionais, mas reconhecido o papel protetivo do Estado, nos seguintes termos:

"Agravo regimental em agravo de instrumento. Contenda resolvida com amparo em normas insertas no Código de Defesa do Consumidor e de legislação correlata. 2. Aferir-se se houve ou não ofensa à Constituição do Brasil demandaria a análise de normas cujos preceitos estão insertos em comandos infraconstitucionais. Agravo regimental a que se nega provimento. (STF $-1^{\mathrm{a}} \mathrm{T}$. $-\mathrm{Ag}$. $\mathrm{Rg}$. no Ag.In 517743/RJ - rel. Min. Eros Roberto Grau - j 31.05.2005 - DJ 24.06.2005). 
em um regramento pelo Estado, mesmo porque para se alcançar o ideal do justo, o direito privado necessita de um pouco do imperium ou da intervenção do Estado. $\mathrm{O}$ favor debilis que mais adiante se verificará é justamente a preocupação de se obter uma maior solidariedade no mercado.

Houve a conscientização da função social do direito privado, ${ }^{6}$ ainda que anteriormente perseguisse apenas fins individuais, o direito privado, deve, da mesma forma, intentar conseguir o bem público e, nesse panorama, não se pode ignorar a existência de cláusulas gerais do Código Civil vigente, por exemplo, função social do contrato, da propriedade, onde a Constituição é o ápice de todo o direito, dada a importância do microssistema protetitvo do consumidor, o qual consagrou normas de ordem pública e interesse social.

Há um fim comum entre o ramo do direito público e privado o que superou a visão absoluta da liberdade dos direitos subjetivos privados, não é mais função exclusiva do direito privado a vida do indivíduo, percebe-se uma limitação na própria autonomia da vontade nas normas de direito privado.

Diante dessa realidade de proteção constitucional do consumidor, inclusive consagrando a vulnerabilidade deste, pretende-se debater a questão do risco do desenvolvimento perante a sociedade atual que anseia a aquisição de novos produtos de forma cada vez mais rápida, sem ao menos ter-se a certeza sobre os impactos que causará.

Nesse panorama, não há como se esquecer de que os riscos são onipresentes e daí decorre o dilema entre assunção de risco e a ética da responsabilidade cada vez mais exigida na sociedade contemporânea, mas ao mesmo tempo deve-se buscar a inserção de limites aceitáveis para que não haja superproteção ao consumidor e não se tolha o próprio desenvolvimento.

Nessa linha de argumentação, não se pode a priori imputar ao fornecedor, à vítima ou ao próprio Estado suportar o dano decorrente do novo produto disponibilizado

\footnotetext{
${ }^{6}$ Julgado do Tribunal do Paraná consagra a função social no direito privado: “Apelação cível - Revisional de contrato - Sistema Financeiro da Habitação - Função social do contrato - Código de Defesa do Consumidor - Contrato de adesão - Plano de equivalência salarial - Inversão do ônus da prova - Taxa de juros - Capitalização - Índice de reajuste das prestações - Substituição da TR pelo INPC. 1. Os contratos de financiamento habitacional devem cumprir com sua função social. Prevista constitucionalmente, ela instrumentaliza-se por princípios esculpidos no Código de Defesa do Consumidor, a saber o equilíbrio contratual e a boa-fé objetiva. 2. As relações jurídicas geradas pelos contratos do SFH revelam-se como de consumo, seja porque as instituições financeiras caracterizam-se como fornecedoras, seja pela presença da vulnerabilidade dos mutuários, caracterizando-os como consumidores. " (TAPR - AP. Cív. 190.834-5 - rel. Juíza Rosana Fachin, j.16.10.2002).
} 
no mercado, ainda que na sociedade de consumo não faça sentido se invocar a responsabilidade subjetiva no âmbito do CDC; há que se admitir excludentes de responsabilidade.

No caso dos riscos do desenvolvimento, a responsabilização do fornecedor ou sua exclusão é traçada por insegurança e dúvidas, sendo, indiscutivelmente prova diabólica para o fornecedor a busca, em todo o mercado, da potencialidade de risco do produto.

Não se distinguirá, nesse aspecto, empresas de grande e pequeno porte e, sem dúvida, esta última será imensamente prejudicada na comprovação de que não existiam pesquisas, suficientes que pudessem comprovar a insegurança do produto.

\subsection{Dos direitos fundamentais}

Os direitos fundamentais surgiram da conjugação dos pensamentos filosóficojurídicos, das ideias do cristianismo e do direito natural. Essas ideias encontravam ponto fundamental em comum, a necessidade de limitação e controle dos abusos de poder do próprio Estado e de suas autoridades constituídas e a consagração dos princípios básicos da igualdade e da legalidade como regentes do Estado moderno e contemporâneo.

Sem dúvida, o Estado tem por objetivo primordial a valorização da própria pessoa, sendo a incidência dos direitos fundamentais, tendo caráter supremo dentro do ente estatal. $^{7}$

\footnotetext{
${ }^{7}$ Guilherme Magalhães Martins elucida que: "O Código de Defesa do Consumidor identifica um novo sujeito de direitos especiais, o consumidor, construindo um sistema de normas e princípios orgânicos para protegêlo e efetivar seus direitos e deflagrando, desde o início da sua vigência, um grande repensar crítico no direito privado.

Trata-se da realização de um direito fundamental (positivo) de proteção do Estado para o consumidor (CR, art. 5], XXXII). Essa localização topográfica do direito do consumidor no texto constitucional o consagra como cláusula pétrea, a salvo da possibilidade de reforma pelo poder constituinte instituído. O consumidor foi ainda identificado constitucionalmente, no art. 28 do ADCT, como agente a ser protegido de forma especial.(...) Em face da doutrina dos direitos fundamentais estabelecida por Robert Alexy, o direito do consumidor pode ser identificado na categoria dos direitos à proteção, exercidos em face do Estado para que este proteja o seu titular das intervenções de terceiros.

Essa proteção deve ser exercida pelo Estado, contra as intervenções de terceiros cabendo ao ente estatal, ao mesmo tempo, promover a defesa desse direito.

Os direitos fundamentais, ensina o professor alemão Dieter Grimm, não se prestam apenas à defesa do cidadão contra o Estado (efeito imediato), mas também protegem o indivíduo nas relações privadas, produzindo efeitos sobre terceiros (“drittewirkung”). Essa eficácia nas relações de direito privado se dá por meio da interpretação das normas legais, em especial das cláusulas gerais.
} 
A noção de direitos fundamentais é mais antiga que o surgimento da própria ideia de constitucionalismo, que tão somente consagrou a necessidade de insculpir um rol mínimo de direitos humanos em um documento escrito, derivado diretamente da soberana vontade popular. ${ }^{8}$

Os antecedentes históricos das declarações de direitos humanos fundamentais mais importantes encontram-se na Inglaterra, no século XIII, na Magna Charta Libertatum, outorgada por João Sem-Terra, a qual previa, entre outras garantias, a proporcionalidade entre delito e sanção, previsão do devido processo legal e livre acesso à justiça.

Já no início do século XX, os diplomas constitucionais foram marcados pelas preocupações sociais. No Brasil, a Constituição do Império já previa um extenso rol de direitos fundamentais. No artigo 179, por exemplo, 35 incisos consagravam direitos e garantias individuais.

Vale lembrar que a Constituição francesa, em 1791, incluiu em seu preâmbulo: "O povo francês convencido de que o esquecimento e o desprezo dos direitos naturais do homem são as causas das desgraças do mundo, resolveu expor, numa declaração solene, esses direitos sagrados e inalienáveis."

Alexandre de Moraes define direitos humanos fundamentais como o conjunto institucionalizado de direitos e garantias do ser humano que tem por finalidade básica o respeito a sua dignidade, por meio de sua proteção contra o arbítrio do poder estatal, e o estabelecimento de condições mínimas de vida e desenvolvimento da personalidade humana. ${ }^{9}$

Tupinambá Nascimento, por outro lado, afirma que não é fácil a definição de direitos humanos, e qualquer tentativa pode significar resultado insatisfatório e não traduzir, para o leitor, a exatidão, a especificidade de conteúdo e a abrangência. ${ }^{10}$

Para Claudia Lima Marques, faz-se mister distinguir entre as funções do direito do consumidor: para as pessoas físicas (art.1 ${ }^{\circ}$, III, CR-88), não se trata apenas de princípio de ordem econômica ou direito econômico social (art.170, CR), mas de um direito fundamental, direito humano positivado.

Para as pessoas físicas, trata-se de um direito fundamental. Para os demais agentes econômicos, especialmente pessoas jurídicas, trata-se especialmente de um sistema limitador da livre iniciativa do art.170, caput, da CR-88, sistema orientador da ordem econômica constitucional brasileira."

${ }^{8}$ MORAES, Alexandre. Direitos humanos fundamentais: teoria geral, comentários aos arts. $1^{\circ}$ a $5^{\circ}$ da Constituição da República Federativa do Brasil, doutrina e jurisprudência. 7. ed. São Paulo: Atlas, 2006. p. 1. ${ }^{9}$ Id. Ibid., p. 21.

${ }^{10}$ NASCIMENTO, Tupinambá. Comentários à Constituição Federal. Porto Alegre: Livr. do Advogado, 1997. p. 211. 
Diante da sua importância, destacam-se algumas características: imprescritibilidade, inalienabilidade, irrenunciabilidade, inviolabilidade, universalidade, efetividade.

No título II da Constituição Federal de 1988 há a previsão dos direitos individuais e coletivos, que correspondem ao conceito de pessoa e sua própria personalidade, como a vida, a dignidade e a honra.

É inegável a importância para os indivíduos, mas há que se ponderar que é indispensável a sua relativização a fim de servir de salvaguarda de práticas ilícitas. ${ }^{11}$

O artigo 29 da Declaração dos Direitos Humanos trouxe essa relativização:

"toda pessoa tem deveres com a comunidade, posto que somente nela pode-se desenvolver livre e plenamente sua personalidade. No exercício de seus direitos e no desfrute de suas liberdades todas as pessoas estarão sujeitas às limitações estabelecidas pela lei com a única finalidade de assegurar o respeito dos direitos e liberdades dos demais, e de satisfazer as justas exigências da moral, da ordem pública e do bem-estar de uma sociedade democrática. Estes direitos e liberdades não podem, em nenhum caso, ser exercidos em oposição com os propósitos e princípios das Nações Unidas. Nada na presente Declaração poderá ser interpretado no sentido de conferir direito algum ao Estado, a um grupo ou uma pessoa, para empreender e desenvolver atividades ou realizar atos tendentes a supressão de qualquer dos direitos e liberdades proclamados nessa Declaração."

Os direitos fundamentais surgem para reduzir a ação do Estado aos limites impostos pela Constituição, sem, entretanto, desconhecerem a subordinação do indivíduo ao Estado.

Dessa forma, o Estado deve ser o promotor da defesa do consumidor, proteção de sua pessoa e de seus interesses existenciais, mesmo porque para se alcançar o ideal do justo, o direito privado necessita de um pouco do imperium ou da intervenção do Estado.

\footnotetext{
${ }^{11}$ Nesse sentido, o Superior Tribunal de Justiça: “ está muito em voga, hodiernamente, a utilização ad argumentandum tantum, por aqueles que perpetram delitos bárbaros e hediondos, dos indigitados direitos humanos. Pasmem, ceifam vidas, estupram, sequestram, destroem lares e trazem dor a quem quer que seja, por nada, mas depois, buscam guarida nos direitos humanos fundamentais. É verdade que esses direitos devem ser observados, mas por todos, principalmente, por aqueles que impensadamente, cometem os censurados delitos trazendo a dor aos familiares das vítimas." ( $6^{\mathrm{a}} \mathrm{T}$. $-\mathrm{RHC} \mathrm{n}^{\mathrm{o}} 2.777-0 / \mathrm{RJ}-$ rel. Min. Pedro Acioli - Ementário STJ, 08/721).
} 


\subsection{Da importância do estudo do risco do desenvolvimento}

A sociedade contemporânea se caracteriza pelo "fenômeno de massa", e, do ponto de vista econômico, a produção é uma produção de massa e, obviamente, o consumo tipicamente de massa. Isso significa dizer que um equívoco de uma pessoa ou de uma empresa envolve milhares de indivíduos, ou seja, basta que um produto apresente um mínimo defeito e milhares de consumidores serão atingidos.

A importância do estudo do risco do desenvolvimento justifica-se, por um lado, pelos inúmeros danos decorrentes da utilização de produtos que na época em que foram introduzidos no mercado não era possível detectar a sua capacidade lesiva e, por outro, que não é possível eliminar toda e qualquer insegurança do mercado, pois, sem dúvida, seria uma missão impossível.

A questão demonstra a sua relevância, pois há o desejo da vítima de não ficar exposta a um ato danoso de eventual fabricante, e questiona-se se efetivamente havia defeito no produto a ponto de responsabilizar o fornecedor, tendo em vista que, na época em que o produto foi introduzido, o estágio mais avançado da ciência não poderia detectar o potencial lesivo.

Em matéria de proteção de saúde e segurança dos consumidores, vige a noção geral da expectativa legítima, ou seja, as expectativas são legítimas no momento em que são confrontadas com o estágio técnico e as condições econômicas da época mostram-se plausíveis, justificadas e reais. O impasse é justamente em delimitar o alcance desse princípio geral da segurança dos bens de consumo.

De fato, os riscos são onipresentes na sociedade; daí a importância de estabelecer se limites aceitáveis diante da infinidade de hipóteses que podem lesionar outrem, como por exemplo, alimentos transgênicos ${ }^{12}$, cosméticos e medicamentos e até mesmo o ambiente de trabalho. ${ }^{13}$

\footnotetext{
${ }^{12} \mathrm{O}$ termo transgênico foi popularizado, mas na verdade, o termo mais correto e abrangente é organismos geneticamente modificados.

${ }^{13}$ Fernando Salvador Moreno, Maria Aparecida Lopes da Costa e Thomas Prates Ong ressaltam que: "Em 1879, foi estabelecida uma relação entre a ocupação profissional e o câncer, Harting e Hesse estabeleciam uma relação com os trabalhadores mineiros da região Floresta Negra, na Alemanha e o câncer de pulmão, cerca de $75 \%$ desses trabalhadores morriam por esse motivo. A causa indicada para estes casos foi a radiação oriunda do urânio das minas. No caso de trabalhadores da indústria de corantes, mais especificamente anilina, Rehn relatava, em 1895, uma relação entre o câncer de bexiga e esse tipo de
} 
Com efeito, com o progresso econômico e social houve um "boom" de ações para proteção do consumidor contra riscos dos produtos, pois se espera segurança máxima, e nessa linha de argumentação define-se como risco até mesmo aquilo que é normal.

O anseio por técnicas cada vez mais avançadas a fim de acompanhar a insatisfação do ser humano faz com que o homem se aventure a suprir vontades e necessidades.

O grande dilema que se coloca no campo do risco do desenvolvimento é quem deve suportar o dano, já que o produtor não tem condições de saber os potenciais danos.

As dúvidas que surgem são inúmeras: de ordem ética, temporal, jurídica e econômica e não se trata de limitar a polêmica apenas sobre quem deve suportar o prejuízo: os consumidores ou os fornecedores.

Estudo aprofundado sobre o tema torna-se imprescindível diante de uma sociedade que convive diariamente com o aumento indiscriminado de produtos lançados no mercado.

Para ilustrar a problemática é válido recordar os problemas causados pela talidomida, remédio utilizado para combater náuseas, prescrito para muitas gestantes, na década de 50 e 60, que acarretou o nascimento de bebês com graves deformações congênitas. Nesse caso, os testes, ainda que numerosos, não conseguiram detectar

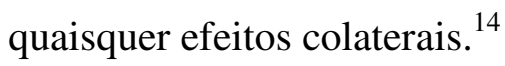

Indiscutivelmente, toda inovação é bem-vinda desde que estudo cauteloso tenha sido feito a fim de apurar eventual impacto maléfico na vida dos homens e ainda provoca

ocupação, sendo sua causa o contato com aminas aromáticas, sobretudo a naftalina (Greenwald e Greenwald, 1983 apud Hazelwood, 1987).

Nesse contexto, Keshavae Ong (1999) ressalta que o ambiente de trabalho pode ser, em muitos casos, fonte de exposição a centenas de agentes nocivos à saúde, como pós e partículas, fumaças e fluidos, fibras, radiação e substâncias químicas." (HIRATA, Mario Hiroyuki; MANCINI FILHO, Jorge. Manual de biossegurança. Barueri: Manole, 2008).

${ }^{14}$ Outro acontecimento lembrado por Maria Angélica Benetti Araújo ocorreu em 1937, quando mais de cem pessoas morreram por insuficiência renal devido ao uso de dietilenoglicol contido no xarope de sulfanilamida. Em 1950, a má utilização de isoproterenol em aerosol, por pacientes asmáticos, levou a uma série de mortes, principalmente na Inglaterra. Entre os casos mais recentes, cita-se o da proibição da venda, no Brasil, de todos os medicamentos que contenham rofecoxibe, princípio ativo do antiinflamatório e analgésico Vioxx, sucesso medicinal desde 1999. Após estudos clínicos conseguiu-se apurar que pacientes tratados com Vioxx por mais de 18 (dezoito) meses correriam mais riscos de ter problemas cardíacos do que os que tomaram placebo. (ARAÚJO, Maria Angélica Benetti. Riscos de desenvolvimento à luz das novas tendências da responsabilidade civil. Revista Trimestral de Direito Civil, Rio de Janeiro, v. 31, jul./set. 2007-Padma, p.42). 
resistência ao uso em razão da dúvida na segurança do produto, muitas vezes pela inintelegibilidade das bulas dos medicamentos, por exemplo. ${ }^{15}$

De uma maneira geral, não há produto ou serviço totalmente seguro, e constata-se que os bens de consumo carregam consigo um resíduo de insegurança. Em regra, o direito atua quando a insegurança ultrapassa o patamar da normalidade e da previsibilidade do risco, no caso do direito do consumidor, quando a legítima expectativa do consumidor foi atingida, ou seja, a insegurança está em desacordo com esta. Sendo assim, todo bem de consumo traz em si o elemento "capacidade de causar acidente", mas para que seja objeto desse ramo do direito é imprescindível que esteja em desconformidade com a expectativa legítima do consumidor.

Questiona-se se realmente o defeito se apresentou, já que o consumidor não teria sido alertado pelo fornecedor do potencial dano que poderia acarretar à sociedade, mas, por outro lado, nenhuma pesquisa até então realizada foi conclusiva no sentido de ocorrência de possíveis danos. Ou ainda há que se ponderar que muitas vezes o próprio Estado permite a comercialização, por exemplo, no caso, de medicamentos.

Tal estudo se reveste de extrema importância diante de uma sociedade massificada e complexa, que depende consideravelmente da indústria e produtos de grande escala para sobreviver. Os dilemas são, de fato, inúmeros e muito condizentes com o mundo globalizado.

Com efeito, a automatização, a produção em série, bem como a distribuição em cadeia, por meio da cisão entre a produção e o comércio são aspectos relevantes, pois, indiscutivelmente, os produtos industrializados há muito tempo deixaram de ser singulares e individualizados.

\footnotetext{
${ }^{15}$ Flavio Finardi Filho e Regina Sorrentino Minazzi Rodrigues asseveram que: "As técnicas de manipulação genética empregadas no desenvolvimento de novas variedades de microrganismos, plantas e animais têm demonstrado um alto potencial para aumentar a produção e a disponibilidade de alimentos, bem como de aumentar o teor de nutrientes em alimentos consumidos por uma grande parcela da população de baixa renda (ABC, 2000). Mas toda inovação conduz a uma reação de resistência ao uso, fundamentada na dúvida da segurança. De modo semelhante ao que ocorreu com a Revolução Verde, que inovou os procedimentos agrícolas e trouxe incertezas quanto à inocuidade dos insumos empregados na lavoura, a tecnologia do DNA recombinante (rDNA) também suscita desconfiança sobre a segurança em consumi-los diariamente. Afinal, esta tecnologia quebrou a barreira natural, que limitava o cruzamento apenas entre indivíduos da mesma espécie, passando a permitir a incorporação de genes até de seres de reinos diferentes, como os de bactérias em plantas e os de animais em microrganismos. Paralelamente possibilita a reintrodução de um gene no tecido de origem após modificação ou mutação in vitro." (HIRATA, Mario Hiroyuki; MANCINI FILHO, Jorge. op. cit.).
} 
A fabricação em massa dos produtos leva a todo o cidadão o risco de exposição, vez que todos são potenciais lesados ao adquirir determinado produto, sendo impossível mensurar o dano que ele possa vir a gerar.

Diante disso, é imprescindível analisar a importância do nexo de causalidade na responsabilidade civil do produtor, tendo em vista que o $\mathrm{CDC}$ não adotou a teoria do risco integral. Impreterivelmente o defeito precisa ser comprovado para que o fornecedor seja responsabilizado. É necessário provar a existência do defeito para que o consumidor seja reparado.

Se para o ramo do direito do consumidor é imprescindível que haja a desconformidade com a sua expectativa legítima, é preciso se questionar se no risco do desenvolvimento houve essa ofensa, ou seja, se a expectativa do consumidor foi efetivamente atingida. Sendo assim, a legítima expectativa deve ser analisada sob o aspecto coletivo da sociedade e não individual, do consumidor-vítima.

\subsection{Origem do direito do consumidor}

\subsubsection{Início do desenvolvimento industrial}

Retrospectiva, ainda que superficial, do desenvolvimento industrial demonstra-se imprescindível para entender o próprio ramo do Direito do Consumidor. ${ }^{16}$

A utilização de máquinas em grande escala surgiu, pela primeira vez, na Inglaterra, acompanhada de mudanças nos métodos de produção, conhecida como Revolução Industrial.

\footnotetext{
${ }^{16}$ Newton De Lucca identifica três fases de evolução da proteção do consumidor: "Na primeira delas, ocorrida após a $2^{\mathrm{a}}$ Grande Guerra, de caráter incipiente, na qual ainda não se distinguiam os interesses dos fornecedores e consumidores, havendo apenas uma preocupação com o preço, a informação e a rotulação adequada dos produtos.

$\mathrm{Na}$ segunda fase, já se questionava com firmeza a atitude de menoscabo que as grandes empresas e as multinacionais tinham em relação aos consumidores, sobressaindo-se, na época, a figura do famoso advogado americano Ralph Nader.

Finalmente, na terceira fase, correspondente aos dias atuais, de mais amplo espectro filosófico - marcada por consciência ética mais clara da ecologia e da cidadania, interroga-se sobre o destino da humanidade, conduzido pelo torvelinho de uma tecnologia absolutamente triunfante e pelo consumismo exagerado, desastrado e trêfego, que põe em risco a própria morada do homem." (DE LUCCA, Newton. Direito do consumidor: teoria geral da relação jurídica de consumo. 2. ed. São Paulo: Quartier Latin, 2008. p. 47-48).
} 
Antes da introdução de máquinas, a produção de um trabalhador estava, na maioria das vezes, limitada pela força de seus músculos, combinada com a habilidade na utilização de ferramentas manuais.

Com efeito, a máquina excedia a força do homem que operava. Um homem utilizando uma máquina poderia produzir muitas vezes mais do que utilizando os velhos métodos, tornando possível a melhora na qualidade de muitos produtos, a redução de custos e o aumento da produção por operário.

Os efeitos industriais vão se estendendo a toda ordem econômica e, consequentemente, à ordem social, que determinam as condições de crescimento e distribuição das riquezas.

A produção ininterrupta torna-se a lei de todas as empresas e o volume se torna essencial para o incremento das vendas, com o intuito de atingir o lucro. ${ }^{17}$ Nessa seara surge a necessidade de uma grande empresa dinâmica e organizada, dando certeza ao mercado em economias de escala, sendo possível prever o início e o seu término, minimizando, de alguma forma, as flutuações do mercado.

A ampliação da circulação trouxe grande progresso e incentivo ao consumo, pois os objetos então inacessíveis, em virtude do alto preço, passaram a ser adquiridos pelos consumidores. ${ }^{18}$

Havia crescente produção em massa, o que criou uma sociedade mais rica e mais complexa; ao se ingressar na era da opulência, mudou-se o objeto central das preocupações político-econômicas, que passou da falta de produção para a busca na qualidade dos produtos ou mercadorias distribuídos no mercado.

\footnotetext{
${ }^{17}$ Paul Mantoux assevera que: “o vencedor é aquele que consegue, apesar de seus rivais, ampliar seu campo de operações, encontrar, ainda e sempre, novos mercados. A ambição dos produtores torna-os aventureiros: os recantos mais longíquos, os continentes recém-explorados, tornam-se suas presas. O mundo inteiro nada mais é do que um só e imenso mercado, que as grandes indústrias de todos os países disputam como a um campo de batalha." (MANTOUX, Paul. A revolução industrial no século XVIII. São Paulo: Unesp, 1985. p. 3).

${ }^{18}$ Thomas Sowell assevera: "There are some relatively simple, but important, principles of economics which together help explain how a complex society of millions of human beings suply one another with the countless goods and services that sustain, enhance, and prolong their lives. Since we know that the key task facing any economy is the allocation of scarce resources which have alternative uses, the next question is: How does an economy do that?" (SOWELL, Thomas. Basic economics: a common sense guide to the economy. 3. ed. New York: Basic Books, 2007. p. 11) Tradução livre: "Existem alguns relativamente simples, mas importantes, princípios econômicos que juntos ajudam a explicar como a complexa sociedade de milhões de seres humanos abastecem uns aos outros com inúmeras mercadorias e serviços que sustentam, melhoram e prolongam suas vidas. Uma vez que sabemos que o elemento-chave para encarar qualquer economia é a alocação de escassas fontes as quais têm usos alternativos, a próxima questão é: Como a economia faz isto?"
} 
Deixou-se de lado a fabricação de produtos singulares com características específicas para um mercado pequeno e restrito para dar lugar a produtos idênticos e padronizados. Verifica-se também que o fator de multiplicação de produtos complexos e sofisticados pode às vezes incapacitar o consumidor na identificação da nocividade do produto. Diante dessa realidade houve o ingresso da figura do consumidor nos textos constitucionais, como objeto de especial cuidado e proteção por parte dos órgãos públicos. $^{19}$

Em 1978, a Constituição espanhola é a primeira a se ocupar do tema; em seu artigo 51 dispõe que: "os poderes públicos garantirão a defesa dos consumidores e usuários, protegendo, mediante procedimentos eficazes, a segurança, a saúde, e os legítimos interesses econômicos dos mesmos."

Vale lembrar que em 1962, o Presidente Kennedy definiu que todos são consumidores em algum momento de suas vidas, inevitavelmente, os indivíduos terão o status de consumidores, situação da qual se pode extrair quatro direitos fundamentais: o direito à segurança, o direito à informação, o direito de escolha e o direito de ser ouvido ou consultado. É direito típico das sociedades capitalistas industrializadas, sendo os riscos do progresso, na medida do possível compensados por uma legislação protetiva.

No Brasil, a Constituição de 1988 consagra a defesa do consumidor no inciso XXXII do artigo $5^{\circ}$ e estabelece que "o Estado promoverá, na forma da lei, a defesa do consumidor" e no inciso V do artigo 170 eleva à condição de princípio da ordem Econômica a defesa do consumidor. ${ }^{20}$

A origem tutelar do direito do consumidor se origina na $\mathrm{CF}$ e posteriormente no Código de Defesa do Consumidor; expressamente o artigo 48 do Ato das Disposições Constitucionais Transitórias determina que o legislador ordinário institua regramento para o Código de Defesa e Proteção do Consumidor: "O Congresso Nacional, dentro de cento e vinte dias da promulgação da Constituição elaborará código de defesa do consumidor."

\footnotetext{
${ }^{19}$ COMPARATO, Fabio Konder. (A proteção ao consumidor na Constituição brasileira de 1988, cit., p. 70).

${ }^{20} \mathrm{O}$ artigo 170 dispõe: "A ordem econômica, fundada na valorização do trabalho humano e na livre iniciativa, tem por fim assegurar a todos existência digna, conforme os ditames da justiça social, observados os seguintes princípios: I - soberania nacional; II - propriedade privada; III - função social da propriedade; IV - livre concorrência; V - defesa do consumidor; VI - defesa do meio ambiente; VII - redução das desigualdades regionais e sociais, VIII - busca do pleno emprego; IX - tratamento favorecido para as empresas de pequeno porte constituídas sob as leis brasileiras e que tenham sua sede e administração no País.”
} 
Houve o surgimento de nova política governamental, segundo a qual não era mais aceitável que o lucro fosse atingido a qualquer custo como se pretendia. Por exemplo, no final do século XVII, Sir Josiah Child, o qual, foi governador da East India Company, sustentava que o empresário produtor devia ser considerado único juiz da qualidade dos produtos. Em suas palavras: "Se quisermos conquistar o mercado mundial devemos imitar os holandeses, que fabricam tanto as melhores quanto as piores mercadorias; é somente assim que poderemos satisfazer todos os mercados e todos os gostos.",21

Por força dos dispositivos constitucionalmente previstos, percebe-se a mudança de preocupação do lucro para a dignidade da pessoa do consumidor, esta, inclusive, alçada a princípio constitucional previsto no inciso III do artigo $1^{\circ}$ da Constituição Federal.

Gustavo Tepedino observa que o que se busca: "é proteger a pessoa humana nas relações de consumo, não já o consumidor como uma categoria de per se considerada, instrumentalizando-se seus interesses patrimoniais à tutela de sua dignidade e valores

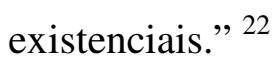

Eros Grau, da mesma forma, refere-se ao tema, asseverando: "A dignidade da pessoa humana é adotada pelo texto constitucional concomitantemente como fundamento da República Federativa do Brasil (art. $1^{\circ}$, III) e como fim da ordem econômica (mundo do ser) (art. 170, caput - 'a ordem econômica (...) tem por fim assegurar a todos existência digna')."23

Por sua vez, José Afonso da Silva esclarece que a dignidade prevista na Constituição Federal

\footnotetext{
"obriga a uma densificação valorativa que tenha em conta o seu amplo sentido normativo-constitucional e não uma qualquer idéia apriorística do homem, não podendo, se reduzir o sentido de dignidade humana à defesa dos direitos pessoais tradicionais, esquecendo-se nos casos de direitos sociais, ou invocá-la para construir 'teoria do núcleo da personalidade'individual, ignorando-a quando se trata de direitos econômicos, sociais e culturais." 24
}

\footnotetext{
${ }^{21}$ COMPARATO, Fabio Konder. op. cit., p. 67.

${ }^{22}$ TEPEDINO, Gustavo. A responsabilidade por acidentes de consumo na ótica civil-constitucional. In: . Temas de direito civil. 2. ed. Rio de Janeiro: Renovar, 2001. p. 250.

${ }^{23} \overline{\mathrm{GRAU}}$, Eros. Contribuição para a interpretação e a crítica da ordem econômica na Constituição de 1988. 1990. Tese (Titular) - Faculdade de Direito, Universidade de São Paulo, São Paulo, 1990. p. 216.

${ }^{24}$ SILVA, José Afonso da. Curso de direito constitucional positivo. 6. ed. São Paulo: Ed. Revista dos Tribunais, 1991. p. 93.
} 


\subsection{Sociedade de consumo}

A sociedade contemporânea é caracterizada pelo fenômeno de massa, o que torna difícil equacionar o conceito de justiça com a sociedade de consumo, pois, sem dúvida, tal fato tornou-se um desafio.

Com efeito, o consumo é parte indissociável do cotidiano de todas as pessoas, pelos mais variados motivos, que vão desde a efetiva necessidade até o simples desejo de adquirir.

Jean Beauchard define a sociedade de consumo como a sociedade de relativa abundância, na qual se encontram satisfeitas as necessidades elementares do maior número de pessoas e onde os consumidores têm, disponível para consumo, aspirações não consideradas essenciais, tais como lazer, conforto, estética e cultura. ${ }^{25}$

Ao invés de se ter o profissional se conformando com as instruções do consumidor, a sociedade de consumo que se apresenta é aquela em que a necessidade se adapta ao produto. Ugo Carnevali alerta para a potencialidade danosa com a mudança estrutural da sociedade; o que representava defeito isolado de um produto singular pode se transformar em um perigo de dano, que acompanha os produtos fabricados pelo empresário. $^{26}$

Não há como eliminar totalmente os acidentes de consumo, a não ser com a supressão do próprio bem, em algumas hipóteses, ou, em outros casos, com a destruição de uma ou algumas de suas qualidades essenciais. De fato, com o aumento da mecanização da produção, proporcionalmente, aumentaram os riscos.

Diante do cenário atual, a tarefa demonstra-se árdua, espelhando uma complexa industrialização, desencadeada pelas inovações e transformações socioeconômicas marcantes e profundas.

Por meio da extrema massificação da produção, da distribuição e do consumo como um todo, foi possível notar a mudança da economia e da proteção do consumidor.

A sociedade que se apresenta hoje é anônima, complexa e desigual. Anônima em razão do desconhecimento do produtor dos bens e do prestador de serviços. Complexa pela

\footnotetext{
${ }^{25}$ BEAUCHARD, Jean. Droit de la distribuition et de la consommation. Paris: PUF, 1996. (Coll. Thémis).

${ }^{26}$ CARVENALI, Ugo. La responsabilitá del produttore. Milano: Giuffrè, 1974. p. 3.
} 
ignorância do procedimento adotado e, por último, desigual, em razão da preponderância econômica, jurídica e técnica do fornecedor. Em virtude desses três aspectos, conclui-se que um controle do mercado e uma intervenção estatal efetivos seriam necessários. ${ }^{27}$

O aparecimento de um defeito pode prejudicar milhares de pessoas, o que acarretará um "dano de massa” e, consequentemente, exigirá resposta protetiva, que deverá tutelar o consumidor.

Nesse compasso, o Estado assumiu papel social mais intenso - o de Estado interventor - a fim de garantir os direitos e interesses dos consumidores.

De fato, anteriormente o próprio mecanismo do mercado regulava os interesses deste, na medida em que as empresas se viam obrigadas a baixar os preços e a melhorar a qualidade dos produtos.

Em razão do princípio da igualdade opunha-se à concessão de qualquer privilégio, pois todos os homens são iguais, produtor e consumidor eram considerados em pé de igualdade.

Com o liberalismo econômico exigia-se um forte abstencionismo do Estado, cabendo aos particulares a regulação econômica. Prestigiava-se a liberdade do comércio e da indústria. De fato, o individualismo estava avesso ao caráter associativo e à intervenção estatal.

Apenas aos poucos houve uma preocupação de proteção dos consumidores; contudo, inicialmente essa proteção foi feita de forma indireta e reflexa do consumidor, através da proibição de concorrência desleal.

Atualmente, há um caráter protecionista do consumidor, em busca do equilíbrio entre a empresa, de um lado, e os consumidores "hipossuficientes", de outro.

Surgiu a sociedade de consumo. O Estado, movido por considerações de caráter social e de natureza política, atualmente intervém para corrigir excessos e proteger o mais fraco, sem, contudo, burocratizar a economia, impedir a iniciativa privada ou até mesmo considerar o consumidor um incapaz, dependente de proteção e assistência para todas as suas vontades.

\footnotetext{
${ }^{27}$ MELLO, Heloisa Carpena Vieira de. Responsabilidade civil no Código de Defesa do Consumidor. Revista de Direito do Consumidor, São Paulo, n. 28, p. 60-61, out./dez. 1998.
} 
No fundo, houve a necessidade de adequação do direito tradicional às novas realidades. Pretende-se a adaptação e melhoria do direito dos contratos, do direito das obrigações.

Dessa forma, o livre jogo da oferta e da procura é substituído por um dirigismo privado. A proteção do consumidor é justificada pela desigualdade de poder (bargaining power).

\subsubsection{Tutela do consumidor}

Como visto no tópico anterior, a necessidade de regulamentação nasceu da prática da sociedade de massa, sob o manto de princípios e valores comuns, de origem constitucional. ${ }^{28}$

\footnotetext{
${ }^{28}$ Guido Alpa e Mario Bessone destacam os problemas da sociedade de massa: "Queste due finalità sono particolarmente evidenti in materia di circolazione di prodotti difettosi. I fenomeni di produzione e distribuzione di massa espongono, il pubblico a rischi sempre più gravi, dovuti ad errori tecnici, defaillances del processo produttivo, negligenze dei dipendenti, che, in vario modo, sono imputabili all'organizzazione dei fattori produttivi. In assenza di una legislazione adeguata, è compito delle regole di diritto privato (e, in particolare, dei principi di responsabilità civile) disciplinare questi fenomeni, e distribuire, nel modo più economico, tra tutti i soggetti della catena di produzione e diffusione della merce, i costi connessi con le conseguenze dannose dell'uso di prodotti difettosi. Ed esaminata nella prospettiva della tutela del consumatore, la disciplina vigente non apare soddisfacente.

In ogni ordinamento la circolazione di prodotti difettosi infatti è stata assoggettata alla disciplina prevista in materia di vendita o di responsabilità civile - dai codici e dalle regole consolidate dalla tradizione. Ed è evidente che principi e regole accreditati in epoca risalente non possono risultare adeguati ai complessi fenomeni del consumo, che, nei sistema capitalisti, richiedono norme intese a realizzare un delicato compromesso tra tutela del pubblico e interessi dell'impresa, protezione dei valori della salute e dell'integrità fisica e dei valori di libertà dell'iniziativa privata.

Ovunque si assiste, pertanto, ad una revisione delle regole della tradizione, che costituisce uno degli aspetti più rilevanti dell' evoluzione che contrassegna ordinamenti codificati e sistemi di case law. Informata ad esigenze di tutela del pubblico, questa revisione ha portato all'affermazione di princìpi di responsabilità (contrattuale ed extracontrattuale) che accollano all'impresa il rischio di danni ai consumatori. Diverse le tecniche e le regole aplicate, diverso il processo storico di adeguamento delle norme ai fenomeni del consumatore che investono anche il problema della diffusione di prodotti difettosi." Em tradução livre: "Estas duas finalidades são particularmente evidentes em matéria de circulação de bens defeituosos. Os fenômenos de produção e distribuição de massa expõem o público a riscos sempre mais graves, devido a erros técnicos, defaillances do processo produtivo, negligências dos empregados, que, de forma variada, são imputáveis à organização dos fatores produtivos. Na ausência de uma legislação adequada, é dever das regras de direito privado (e, particularmente, dos princípios de responsabilidade civil) disciplinar esses fenômenos, e distribuir, no modo mais econômico, entre todos os sujeitos da cadeia de produção e difusão das mercadorias, os custos vinculados com as consequências danosas do uso dos produtos defeituosos. E examinada na perspectiva da tutela do consumidor, a disciplina vigente não parece satisfatória. Em cada ordenamento, a circulação de produtos defeituosos de fato estava submetida à matéria prevista - matéria de venda ou de responsabilidade civil nos códigos e nas regras tradicionalmente consolidadas. E é evidente que princípio e normas válidas em épocas passadas não podem resultar adequados aos complexos fenômenos do consumo, que, nos sistemas capitalistas, clamam por normas destinadas a realizar delicado
} 
J. M. Othon Sidou, na década de 70, antes mesmo da elaboração do Código, já identificava a necessidade de proteger o consumidor na sociedade de consumo. Segundo o autor, a proteção ao consumidor importa num complexo no qual se manifesta uma multidão de situações e problemas que, se por um lado identificam-se na natureza econômica e em certos aspectos jurídicos, por outro, diversificam-se em configuração polimórfica, importância incalculável e intensidade imponderável. ${ }^{29}$

Diante da constatação da desigualdade de posição e de direitos entre o consumidor e o fornecedor, houve a constatação da insuficiência de outros ramos do direito, como por exemplo, direito civil e direito comercial, no âmbito do direito privado e no direito público, penal e administrativo para a proteção do consumidor.

É possível explicar o direito do consumidor pela evolução e relativização dos dogmas do próprio direito privado, tais como, a autonomia da vontade, o contrato, os poderes do crédito e o pacta sunt servanda.

Para Claudia Lima Marques, existem três maneiras de analisar o direito do consumidor, no Brasil. A primeira foi por meio de introdução sistemática, sistema de valores e direitos fundamentais que a Constituição Federal de 1988 impôs no Brasil. A segunda, mediante a filosofia de proteção dos mais fracos ou do princípio tutelar favor debilis, que orienta o direito dogmaticamente, em especial as normas do direito que se aplicam a esta relação de consumo. Por fim, para a autora, a terceira poderia ser denominada de introdução socioeconômica ao direito do consumidor.

Sob a ótica sistemática, o direito do consumidor é reflexo dos direitos constitucionalmente garantidos. Em outras palavras, a CF de 1988 seria a origem de codificação tutelar dos consumidores no Brasil, sob mandamento constitucional, o de promover a defesa dos consumidores, nos termos do inciso XXXII artigo $5^{\circ}$ da CF; de observar e assegurar como princípio geral da atividade econômica, como princípio

compromisso entre a tutela do interesse público e os interesses da empresa, proteção dos valores da saúde e da integridade física e dos valores de liberdade da iniciativa privada.

Em todo lugar se presencia, portanto, a uma revisão das regras da tradição, que constitui um dos aspectos mais relevantes da evolução que distingue os ordenamentos codificados e sistemas de case law.

Informada pela exigência da tutela do público, esta revisão trouxe a afirmação dos princípios de responsabilidade (contratual e extracontratual) que (....) à empresa e risco dos danos aos consumidores. Diversas as técnicas e as regras aplicadas, diverso é o processo histórico da adequação das normas aos fenômenos do consumo que assumem também o problema da difusão de produtos defeituosos. (ALPA, Guido; BESSONE, Mario. La responsabilità del produttore. Milano: Giuffrè, 1987. p. 1-2).

${ }^{29}$ SIDOU, J. M. Othon. Proteção ao consumidor. Rio de Janeiro: Forense, 1977. p. 1. 
imperativo da ordem econômica constitucional, a necessária "defesa" do sujeito de direitos do "consumidor".

A supracitada autora entende que certos são aqueles que consideram a Constituição Federal de 1988 como o centro irradiador e o marco de reconstrução de um direito privado brasileiro mais social e preocupado com os vulneráveis de nossa sociedade - um direito privado solidário. Em sua opinião, a Constituição seria a garantia e o limite, centro valorativo, de um direito privado construído sob seu sistema de valores e no qual se inclui a defesa do consumidor. ${ }^{30}$

A proteção do consumidor consistiria da autonomia da vontade dos fortes em relação aos vulneráveis debilis, para construir um novo direito privado mais consciente de sua função social.

O princípio do favor debilis é a superação da ideia de que basta a igualdade formal, como se encontrava no direito civil do século XIX; é o próprio reconhecimento de que alguns são mais fortes ou ainda que possuem posição jurídica favorável, transferem mais facilmente seus riscos e custos profissionais para os outros. ${ }^{31}$

É a presunção de vulnerabilidade, prevista no inciso I do artigo $4^{\circ}$ do CDC, seja porque têm mais informações, são profissionais ou têm posição jurídica mais forte, pois em geral os outros são leigos e supostamente vítimas mais fáceis de abusos.

De fato, para alcançar a igualdade material é necessário limitar também a liberdade de alguns e estabelecer uma maior solidariedade no mercado favor debilis e assegurar direitos indisponíveis por vontade das partes, ou seja, direitos de ordem pública aos mais fracos. ${ }^{3233}$

\footnotetext{
${ }^{30}$ MARQUES, Claudia Lima. Contratos no Código de Defesa do Consumidor: o novo regime das relações contratuais. 4. ed. São Paulo: Ed. Revista dos Tribunais, 2002. p. 27.

${ }^{31}$ Id. Ibid., p. 31.

${ }^{32}$ Claudia Lima Marques observa com acuidade: “Em outras palavras, igualdade supõe uma comparação, um contexto, uma identificação no caso, como na relação entre o leigo e o profissional, o consumidor e o fornecedor de produtos e serviços. A igualdade só pode ser abordada sob o ponto de vista de uma comparação. Eis aqui o desafio maior do direito privado brasileiro atual, em face da unificação do regime das obrigações civis e comerciais no Código Civil de 2002 e em face do mandamento constitucional de discriminar positivamente e tutelar de forma especial os direitos dos consumidores (art. $5^{\circ}$, XXXII, da $\mathrm{CF} / 88$ ), também em suas relações civis. A igualdade perante a lei e a igualdade na lei só podem realizar-se hoje, no direito privado brasileiro, se existir a distinção entre fracos e fortes, entre consumidor e fornecedor, e se for efetivo um direito tutelar do consumidor, daí a importância desta nova visão tripartite do direito privado, que é centrada na dignidade da pessoa humana e na idéia de proteção do vulnerável, o consumidor." (Id. Ibid., p. 33).

${ }^{33}$ Celso Antônio Bandeira de Mello observa: "A dizer: o que permite radicalizar alguns sob a rubrica de iguais e outros sob a rubrica de desiguais? Em suma:qual o critério legitimamente manipulável - sem
} 
Hans Kelsen elucida:

"A igualdade dos sujeitos na ordenação jurídica, garantida pela Constituição, não significa que estes devam ser tratados de maneira idêntica nas normas e em particular nas leis expedidas com base na Constituição. A igualdade assim entendida não é concebível: seria absurdo impor a todos os indivíduos exatamente as mesmas obrigações ou lhes conferir exatamente os mesmos direitos sem fazer distinção alguma entre eles, como, por exemplo, entre crianças e adultos, indivíduos mentalmente sadios e alienados, homens e mulheres." 34

O princípio de proteção do consumidor fez com que alguns dogmas fossem relativizados, tais como autonomia da vontade e força obrigatória dos contratos para que ocorresse uma interpretação integrativa. As mudanças sociais e econômicas na produção e distribuição dos produtos levaram à regulação especial do consumo, não colocando mais o consumidor na posição de "rei" do mercado. ${ }^{35}$

A tendência é a valorização dos direitos humanos fundamentais e dos novos papéis sociais e econômicos, que a doutrina alemã denomina de Solidarprivatrech, ou

agravos à isonomia - que autoriza distinguir pessoas e situações em grupos apartados para fins de tratamentos jurídicos diversos? Afinal, que espécie de igualdade veda e que tipo de desigualdade faculta a discriminação de situações e de pessoas, sem quebra e agressão aos objetivos transfundidos no princípio constitucional da isonomia?" (MELLO, Celso Antônio Bandeira de. O conteúdo jurídico do princípio da igualdade. 3. ed. São Paulo: Malheiros, 2006).

${ }^{34}$ KELSEN, Hans. Teoria pura do direito. Tradução francesa da 2. ed. por Ch. Einsenmann, Paris: Dalloz, 1962. p. 190.

${ }^{35}$ Nesse mesmo sentido Guido Alpa: "In altri termini, il consumatore non è piú il re del mercato (...); oggi (...) non soltanto non regna ma stenta a difendersi non solo dagli 'imperi' delle grandi imprese industriali, ma anche dai piccoli e pur fastidiosissimi "ducati" e "contee" che affollano la rete della distribuzione. In modi diversi, queste forze allontanano il mercato dal servizio del consumatore. Il consumatore diventa uno strumento della produzione; ed il mercato, lungi da riflettere direttive ispirate alla massima linertà degli operatori, apare come il luogo dove si registrano le prevaricazioni delle grandi imprese. In tal modo l'economia si svilupa non per canali dipendenti da libere e consapevoli scelte delle persone singole o dei grupi sociali, quali realtà autonome, ma per 1' influsso continuo e assillante delle esigenze della strutura oligopolista a cui l'intera società viene, quasi inconsapevolmente, strumentalizzata."

Tradução livre: Em outros termos, o consumidor não é mais o rei do mercado; hoje não somente não reina, mas custa a defender-se dos impérios das grandes empresas industriais como também dos pequenos e exigentes "ducados" e "condados" que incluem a rede da distribuição. De modos diversos, essas forças distanciam o mercado do serviço ao consumidor. O consumidor se torna um instrumento da produção; e o mercado, longe de refletir diretivas inspiradas pela máxima clareza dos operadores, surge como o lugar onde se registram as prevaricações das grandes empresas. De tal modo, a economia se desenvolve não por canais dependentes de escolhas livres e conscientes de indivíduos ou grupos sociais, realidades autônomas, mas pelo influxo contínuo e obsessivo da estrutura oligopolista pela qual a inteira sociedade vem, quase inconscientemente, sendo explorada.

Em outro modo, estas forças afastam o mercado do serviço do consumidor. O consumidor torna um instrumento da produção; e o mercado.

(ALPA, Guido. Tutela del consumatore e controlli sull'impresa. Bologna: Società Editrice Il Mulino, 1977. p. 15). 
"direito privado solidário" usada por Hannes Rosler, em Europäisches Konsumentenvertragsrecht. ${ }^{36}$

O inciso I do artigo $6^{\circ}$ assegura um direito de proteção da vida, saúde e segurança, como os mais elementares direitos do consumidor, sendo que se está diante de uma sociedade de risco. Além disso, o CDC garante a liberdade de escolha na hora da contratação, até para que se evite a discriminação de consumidores, bem como o direito à informação, à transparência e boa-fé e proteção contratual.

Deu-se nova roupagem ao direito privado ao se priorizar a igualdade dos mais fracos, com concretas medidas de proteção e com o objetivo de se alcançar a solidariedade, que seria intermediária entre o interesse centrado em si e o interesse voltado para o outro. Houve a conscientização da função social do direito privado onde a Constituição é o ápice de todo o direito. ${ }^{37}$

Nos artigos posteriores houve a consagração da teoria da qualidade, não apenas qualidade-segurança, mas também qualidade-adequação dos produtos. Os fornecedores têm o dever de colocar no mercado produtos e serviços que sejam considerados seguros e, em razão disso, foi possível afirmar que houve a quebra da summa divisia entre a responsabilidade contratual e extracontratual. Com efeito, o fator principal consiste em

\footnotetext{
${ }^{36}$ MARQUES, Claudia Lima. op. cit., p. 27.

${ }^{37}$ Claudia Lima Marques com acuidade ensina que: "Esta elevação à Constituição Federal de matérias originariamente apenas tratadas em leis infraconstitucionais de direito privado, como as relações privadas e de consumo, facilita identificar eficácias das normas constitucionais às relações privadas, isto é, uma influência recíproca entre os direitos públicos e privado, a partir da CF 88, destacando a função social do direito privado, como previa Gierke. Mencione-se que este fenômeno, de "migração" dos princípios do direito civil para o direito constitucional, pode ser visto de duas maneiras. Ou negativamente, seja como uma perda de "autonomia" valorativa do direito privado, antes centro científico do direito, uma vez que sua racionalidade teria sido "colonizada" pelos valores da Constituição, seja como uma abertura sistemática ampla para uma superrevisão (Superrevision - Schwabe, P. 470), que afetaria a "segurança juridica" dos negócios entre privados. Ou pode ser vista, como aqui estamos a fazer, positivamente, como uma garantia reforçada da instituição do direito privado, por exemplo, uma garantia da proteção dos interesses do consumidor na relação frente aos agentes do sistema financeiro nacional em suas relações obrigacionais contratuais e extracontratuais, uma garantia da própria segurança jurídica (proteção dos direitos adquiridos, proibição de retrocesso, proibição de exagero ou Übermassverbot ou proporcionalidade - veja SARLET, Ingo. A eficácia do direito fundamental à segurança jurídica: dignidade da pessoa humana, direitos fundamentais e proibição de retrocesso social no direito constitucional brasileiro. In: BERMUDES, Sérgio et al. Constituição e segurança jurídica: direito adquirido, ato jurídico perfeito e coisa julgada, cit, p. 85 e ss.). E também como um limite à atuação dos privados (veja MENDES, Gilmar Ferreira. Direitos fundamentais: eficácia das garantias constitucionais nas relações privadas: analise da Jurisprudência da Corte Constitucional Alemã. Cadernos de Direito Constitucional e Ciência Política, São Paulo, v. 7, n. 27, p. 33 e ss., abr./jun. 1999), que assegura proteção aos mais fracos e ordem harmônica na sociedade, segundo valores máximos constitucionalizados, garantindo uum direito de proteção contra o abuso do direito, contra o exercício para lá dos fins sociais e econômicos do contrato, dos bons costumes ou da boafé, que assegura a própria autonomia do indivíduo e a dignidade nas relações com os mais fortes." (MARQUES, Claudia Lima; BENJAMIN, Antônio Herman; BESSA, Leonardo Roscoe. Manual de direito do consumidor. São Paulo: Ed. Revista dos Tribunais, 2008. p. 29).
} 
assegurar proteção a toda cadeia de consumidores, sejam eles contratantes diretos, por meio da responsabilidade contratual ou não. Sendo assim, o mercado de consumo exige que haja qualidade e segurança dos produtos e serviços, fruto do princípio de confiança e de segurança. ${ }^{38}$

Por outro lado, Newton de Lucca com precisão pondera que o direito do consumidor não pode ser compreendido apenas como disciplina tutelar e a ponto de apenas reconhecer que o fundamento axiológico de todo o direito nada mais seria do que a submissão estrutural mencionada por Norbert Reich. ${ }^{39}$

Afirma que, a par dessa inquestionável submissão estrutural diante da vulnerabilidade do consumidor e da realidade da empresa, o consumidor deve ser encarado como um elo fundamental para que o ciclo das relações econômicas seja completado. Indaga-se, ainda, a extensão, o conteúdo e o significado do movimento deflagrado no mundo, em favor do consumidor, mesmo porque a própria empresa, com o seu dinamismo e poder de transformação, até mesmo pode servir como elemento explicativo e definidor da civilização contemporânea.

\footnotetext{
${ }^{38}$ Roger Bowles com acuidade pondera: "La regolamentazione della qualità del prodotto è molto estesa. Il significato del termine prodotto è in questo caso estremamente ampio e comprende ogni sorta di beni e di servizi. La base logica per imporre um minimo di standard qualitativi su molti tipi di prodotto poggia non tanto sul fatto che il bene abbia una qualità adeguata quanto sul fatto che può essere meno costoso e più sicuro che i test qualitativi siano espletati da ispetori pubblici piuttosto che dai consumatori stessi. I soggetti che comprano un'automobile non devono preoccuparsi tropo, giacché se la macchina dovesse dare dimostrazione di essere difettosa, grazie alla struttura dei contratti che regolano tali vendite, possono facilmente pretendere che questa sia riparata o sostituita. Quando un soggetto compra una nuova casa può però essere più costoso fare ricorso ai mezzi di tutela accordata all'acquirente contro gli eventuali inconvenienti. Questi ultimi possono manifestarsi dopo molto tempo o può essere difficile stabilire con chiarezza se il difetto è dovuto alla negligenza dell'apaltatore $\mathrm{o}$, peggio, del subapaltatore. Ispettori pubblici che controllano la costruzione durante la sua edificazione e che assicurano il rispetto delle norme dettate dalla disciplina edilizia potrebbero rapresentare una soluzione poco costosa a questo problema. I costruttori onesti per esempio accoglieranno favorevelmente questa regolamentazione poiché ridurrebbe il campo d'azione di chi costruisce case di cattiva qualità per poi scomparire dalla scena e andare a commerciare in un posto diverso o sotto falso nome." Em tradução livre, o autor: A regulamentação da qualidade do produto é muito ampla. O significado do termo produto, é neste caso, extremamente extenso e compreende toda a sorte de bens e serviços. A base lógica para impor um mínimo de patamar qualitativo a muitos tipos de produtos se fundamenta não tanto no fato de que o bem tenha uma qualidade adequada quanto no fato de que pode ser menos custoso e mais seguro que os testes de qualidade sejam levados a cabo por inspetores públicos do que pelos próprios consumidores. Os indivíduos que compram um automóvel não devem se preocupar muito, já que se o carro der demonstração de ser defeituoso, graças à estrutura dos contratos que regulam tais vendas, podem facilmente pretender que este seja consertado ou substituído. Quando um sujeito adquire uma casa nova pode ser mais custoso recorrer aos meios de tutela atribuída ao adquirente contra os eventuais inconvenientes. Estes últimos podem se manifestar depois de muito tempo ou pode ser difícil estabelecer com clareza se o defeito se deve à negligência do empreiteiro ou pior, do subempreiteiro. Inspetores públicos que controlam a construção durante sua edificação e que asseguram o respeito às normas impostas pela disciplina edílica poderiam representar uma solução menos custosa a este problema. Os construtores honestos, por exemplo, acolherão favoravelmente essa regulamentação, pois reduziria o campo de ação de quem constrói casas de má qualidade para depois desaparecer de cena e comercializar em outro lugar ou sob nome falso. (BOWLES, Roger. Diritto e economia. Bologna: Il Mulino, 1985. p. 233).

${ }^{39}$ DE LUCCA, Newton. op. cit., p. 66.
} 
O supracitado autor, ainda assim, admite que o direito mercantil moderno não está mais confinado a legitimar a estrutura de poder econômico apenas representada pela classe empresarial, pois o Estado Social tem o direito de deslocar, das mãos dos empresários, o eixo de rotação do mercado, não o deixando apenas no cerne exclusivo da produção, mas deslocando-o para o binômio produção/consumo. ${ }^{40}$

Jean Calais-Auloy mostra que existem duas concepções básicas, sendo uma aplicável ao ato de consumo e a outra, que o direito do consumo seria o conjunto de regras aplicáveis à proteção dos consumidores. ${ }^{41}$

De fato, o poder econômico tem sua função social, de serviço à coletividade e, em última análise, o mercado é sempre organizado em razão do consumidor, mesmo porque está fundamentado em um regime de produção essencialmente concorrencial. Com efeito, o monopólio é sempre combatido. ${ }^{42}$

Dessa forma, impõe-se esclarecer que o direito do consumidor, muito embora esteja fundamentalmente voltado a protegê-lo, já que se encontra em posição de vulnerabilidade, não pode ser o único amparado, na medida em que não é o personagem exclusivo dessa relação jurídica.

\footnotetext{
${ }^{40}$ DE LUCCA, Newton. op. cit., p. 68.

${ }^{41}$ Vale transcrever as palavras do autor: "Le droit de la consommation comprendra, dans cet ouvrage, non seulement les règles aplicables aux actes de consommation, mais encore celles qui tendent à protéger les consommateurs, même si elles n s'apliquent pas directement à eux." (CALAIS-AULOY, Jean. Droit de la consommation. 4. ed. Paris: Dalloz, 1996. n. 2).

Em tradução livre: "O direito do consumo compreende, nesta obra, não somente as regras aplicáveis aos atos de consumo, mas também aquelas que objetivam proteger os consumidores, mesmo se elas não se aplicam diretamente a eles."

${ }^{42}$ Fabio Konder Comparato também elucida a questão do binômio produção/consumo: Os economistas contemporâneos modernos estão em vias de liquidar a noção clássica de mercado, sobre a qual se fundou toda a análise econômica não marxista desde Adam Smith. Na concepção tradicional, o mercado sempre organizado em função do consumidor, cujas decisões fundamentam, em última análise, a correspondência entre ofertas e demandas, num regime de produção essencialmente concorrencial. A situação de monopólio é considerada excepcional e combatida como autêntica aberração. Hoje, reconhece-se que o mercado de bens, serviços e de força-trabalho é formado pelas decisões do conjunto de empresas dotadas de poder econômico, ao qual se submetem todas as demais unidades, pequenas ou médias. As relações que se estabelecem entre esses setores, o nuclear e o periférico, são em tudo análogas ao relacionamento entre países desenvolvidos e subdesenvolvidos. O poder econômico, portanto, é a regra e não a exceção. Ora, a finalidade última desse poder, do qual todos nós dependemos, não pode ser apenas, nem principalmente, a produção e a partilha de lucros entre proprietários e capitalistas; não deve ser, tampouco, assegurar ao empresário um nível de elevada retribuição econômica e social. O poder econômico é uma função social, de serviço à coletividade. (COMPARATO, Fabio Konder. O poder de controle na sociedade anônima. São Paulo: Ed. Revista dos Tribunais, 1975. Tese de concurso para provimento do cargo de Professor Titular da Faculdade de Direito da Universidade de São Paulo. p. 406).
} 


\title{
CAPÍTULO II. DOS PRINCIPAIS ASPECTOS DO CDC
}

\author{
SUMÁRIO: 2. DOS PRINCIPIAIS ASPECTOS DO CÓDIGO DE DEFESA DO \\ CONSUMIDOR. - 2.1 DA VULNERABILIDADE DO CONSUMIDOR. - 2.2 DA \\ PRESENÇA DO ESTADO NO PODER ECONÔMICO. - 2.2.1 DA EVOLUÇÃO DA \\ RESPONSABILIDADE DO ESTADO. - 2.2.2 DA OMISSÃO DO ESTADO. - \\ 2.2.3. DO DIREITO À SAÚDE. - 2.3. DA LIVRE INICIATIVA E PROTEÇÃO DO \\ CONSUMIDOR. - 2.3.1 DO CONFLITO ENTRE EMPRESA E CONSUMIDOR.
}

\section{Dos principais Aspectos do código de defesa do consumidor}

\subsection{Da vulnerabilidade do consumidor}

O reconhecimento da vulnerabilidade do consumidor foi, sem dúvida, a grande justificativa para que se implementasse sua tutela. É a espinha dorsal do Código, a base de todo o seu estudo, a sua filosofia. ${ }^{43}$

\footnotetext{
${ }^{43}$ João Batista de Almeida assevera que: "Essa relação de hipossuficiência é multiforme, podendo ocorrer por desinformação, quando consome medicamento sugestionado pela massiva propaganda dos meios de comunicação ou influenciado por orientação desqualificada, sem estar informado corretamente de sua indicação ou dos efeitos nefastos à sua saúde. Também pode ocorrer por fraude, quando lhe vendem farinha de trigo embalada como antibiótico ou o adoçante artificial sacarina, de preço menor e prejudicial à saúde se consumido em grandes quantidades, embalado como se fosse adoçante natural stévia, mais caro e inofensivo ao organismo. Pode ocorrer, ainda, quando o produtor não dê ou não honre a garantia ao bem produzido, como no caso do eletrodoméstico que se estraga no dia da compra ou logo após e o produtor se esquiva de substituir o produto defeituoso ou até mesmo as peças que impedem o seu perfeito funcionamento. Nessa extensa lista, que poderia ser aumentada casuisticamente muitas vezes, chega-se à conclusão de que o consumidor não está educado para o consumo, e que, em razão disso, é lesado por todos os modos e maneiras, diuturnamente, e vê, com frequência, serem desrespeitados os seus direitos básicos consagrados pela ONU e pela legislação brasileira, como saúde e segurança, escolha, informação e ressarcimento." (ALMEIDA, João Batista de. A proteção jurídica do consumidor. 6. ed. São Paulo: Saraiva, 2008. p. 24-25).

Vale transcrever o seguinte julgado: “Agravo DE Instrumento. AÇão Civil PúblicA. Decisão QUE DETERMINOU A APLICAÇÃO DE MULTA EM CASO DE DESCUMPRIMENTO E INVERTEU DO ÔNUS DA PROVA EM FAVOR DO MINISTÉRIO PÚBLICO.

Levando-se em conta que o agravante não juntou aos autos nenhum documento que comprovasse de que forma a aplicação de multa de $\mathrm{R} \$ 20.000,00$ poderia inviabilizar o seu funcionamento, cingindo-se a simplesmente formular meras alegações quanto a supostas dificuldades inerentes ao risco empresarial da operação, deve ser mantida a decisão a quo.

$\mathrm{O}$ art. $6^{\circ}$, inciso VIII, da Lei $\mathrm{n}^{\circ}$ 8.078/90 (Código de Defesa do Consumidor), que é aplicável à Ação Civil Pública em razão do disposto no art.21 da Lei $\mathrm{n}^{\circ}$ 7.347/85, prevê a facilitação dos direitos do consumidor, inclusive com a inversão do ônus da prova, a seu favor, no processo civil, quando, a critério do juiz, for verossímil a alegação ou quando for ele hipossuficiente, segundo as regras ordinárias de experiência. Este é exatamente o caso dos autos, considerando o interesse difuso dos consumidores e a hipossuficiência técnica decorrente das ações coletivas de consumo. Contrastando, nessa ótica, com a superioridade da empresa fornecedora, que dispõe de elementos com maior facilidade de comprovação da regularidade da sua atuação."

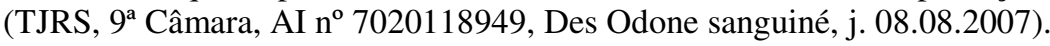


Antônio Herman Benjamin diferencia a vulnerabilidade da hipossuficiência nos seguintes termos:

\begin{abstract}
" a vulnerabilidade é um traço universal de todos os consumidores, ricos ou pobres, educados ou ignorantes, crédulos ou espertos. Já a hipossuficiência é marca pessoal, limitada a alguns - até mesmo a uma coletividade - mas nunca a todos os consumidores. A vulnerabilidade do consumidor justifica a existência do Código. A hipossuficiência, por seu turno, legitima alguns tratamentos diferenciados no interior do próprio Código como, por exemplo, a previsão de inversão do ônus da prova (art. $6^{\circ}$, VIII)., ${ }^{44}$
\end{abstract}

No âmbito constitucional, a vulnerabilidade foi reconhecida de forma implícita, ao contrário do inciso I do artigo $4^{\circ}$ do Código de Defesa do Consumidor, que declarou, tal característica, como um dos princípios da Política Nacional de Relações de Consumo.

A vulnerabilidade, para Eros Grau, é a norma-objetiva informativa, por meio da qual os fins são perseguidos pelo sistema jurídico, de modo que todas as demais normas do CDC, consideradas normas de conduta ou normas de organização, devem instrumentalizar a realização dos fins previstos no artigo $4^{\circ}$, ou seja, devem ser interpretadas teologicamente, finalisticamente, não por opção do intérprete, mas porque essa é uma imposição do próprio Código. ${ }^{45}$

A tutela do consumidor também se justifica no sentido de harmonização dos interesses dos participantes das relações de consumo. Busca-se o equilíbrio na relação empresa e consumidor, nos termos do inciso III do artigo $4^{\circ}$.

O equilíbrio pode ser alcançado seja por meio de informação bem prestada, seja por meio da proteção ao consumidor ou ainda fornecendo-lhe instrumentos para reduzir os conflitos que surgem.

Além da função econômica e particular de circulação de riqueza, a função social deve necessariamente envolver o próprio reconhecimento da vulnerabilidade quando a pessoa adota o status de consumidor. Seria o reconhecimento da crise de legitimação ou de confiança que aumenta a posição de vulnerabilidade do consumidor.

João Batista de Almeida ressalva que em uma consideração utópica poder-se-ia atingir o equilíbrio colocando o consumidor em condição de igualdade em face do

\footnotetext{
${ }^{44}$ BENJAMIN, Antônio Herman. Comentários ao Código de Defesa do Consumidor. 3. ed. São Paulo: Ed. Revista dos Tribunais, 2006. p. 224-225.

${ }^{45} \mathrm{GRAU}$, Eros. Interpretando o Código de Defesa do Consumidor: algumas notas. Revista de Direito do Consumidor, São Paulo, n. 5, p. 188, jan./mar. 1993.
} 
empresário e sem mais necessidade de tutela. O consumidor seria emancipado, não seria hipossuficiente, nem vulnerável. ${ }^{46}$

Fernando Büscher Von Teschenhausen Eberlin elucida que a lei consumerista brasileira objetiva proteger o vulnerável, nos termos do artigo $4^{\circ}$, inciso I do CDC. E complementa, ao citar Claudia Lima Marques: vulnerável é aquele que está em uma situação permanente ou provisória, individual ou coletiva, que fragiliza, enfraquece o sujeito de direitos, desequilibrando a relação. ${ }^{47}$

Segundo a supracitada autora, é possível dividir a vulnerabilidade em três espécies: técnica, jurídica e fática.

A vulnerabilidade técnica é o desconhecimento pelo consumidor das qualidades intrínsecas dos produtos, dos meios empregados em sua produção ou dos riscos que o mesmo possa apresentar. O adquirente não possui conhecimentos específicos sobre o objeto que está comprando e pode ser mais facilmente enganado quanto às características do bem. No caso do consumidor não profissional, a vulnerabilidade técnica é presumida ${ }^{48}$, e excepcionalmente pode atingir o profissional, na hipótese de ser o destinatário final fático do bem.

Já a vulnerabilidade jurídica ou contábil retrata a ignorância do valor e do alcance dos termos jurídicos empregados em um contrato ou como a impossibilidade de realização de uma perícia contábil. Foi identificada como a falta de conhecimentos específicos jurídicos, contabilidade e economia. A vulnerabilidade é presumida, e, por outro lado, no caso dos profissionais e das pessoas jurídicas vale a presunção em contrário, isto é, devem possuir conhecimentos jurídicos mínimos.

E, por fim, a vulnerabilidade fática ou socioeconômica é o monopólio fático ou jurídico, é a desproporção fática, em caráter intelectual e econômico, que caracteriza a relação de consumo.

\footnotetext{
${ }^{46}$ ALMEIDA, João Batista de. op. cit., p. 35.

${ }^{47}$ EBERLIN, Fernando Büscher von Teschenhausen. O concorrente como consumidor equiparado: proteção ao consumidor contra práticas abusivas por meio do diálogo entre o $\mathrm{CDC}$ e as normas concorrenciais. Revista de Direito do Consumidor, São Paulo, ano 17, n. 67, p. 12, jul./set. 2008.

${ }^{48} \mathrm{~A}$ presunção da vulnerabilidade da pessoa física combinada com o artigo $2^{\circ}$ é enfrentada na seguinte decisão:

"Agravo no agravo de instrumento - Contrato de abertura de crédito - aplicabilidade do CDC - Comissão de permanência - Inacumulabilidade com juros moratórios e multa contratual - Súmula 83 desta Corte. (...) II Tratando-se de contrato firmado entre a instituição financeira e pessoa física, é de se concluir que o agravado agiu com vistas ao atendimento de uma necessidade própria, isto é, atuou como destinatário final. Aplicável, pois, o CDC.” (STJ - 3ª T. - Ag.Ag.In. 296.516/SP - rel. Min. Fátima Nancy Andrighi, j. 07.12.2000).
} 
Dessa forma, a vulnerabilidade é a tentativa de romper a igualdade formal em favor de igualdade substancial.

\subsection{Da presença do Estado no poder econômico}

Os governos devem prover uma infraestrutura adequada à política de proteção ao consumidor e, por outro lado, incumbe às empresas a subsunção às normas estabelecidas pelo Poder Público ${ }^{49}$. De fato, o imperativo da proteção do consumidor foi guindado a postulado político, o que explica o crescente empenho na matéria pelos órgãos legiferantes. ${ }^{50}$

\footnotetext{
${ }^{49}$ Washington Peluso Albino de Souza observa: "Quando o Estado exerce poder no 'domínio econômico', ou seja na área da realidade econômica, caracteriza-se o Poder Econômico do Estado. O exercício desse poder implica medidas de política econômica, quer em relação à economia interna corporis, sua própria administração, quer no espaço econômico externo, ou atividade econômica fora da sua própria administração. Desta, deparamos com áreas antes reservadas à iniciativa privada, quando disciplina a atividade econômica do particular, do mesmo a do Estado-empresário, na medida em que os seus efeitos se fazem sentir, ou em que os seus interesses extrapolam o âmbito das relações privadas, e se protejam no todo social.”( SOUZA, Washington Peluso Albino de Souza. Primeiras linhas de direito econômico. 5. ed. São Paulo: LTr, 2003. p. 314).

${ }^{50}$ João Calvão da Silva observa: "Esse imperativo, o imperativo da protecção do consumidor, rapidamente foi guindado a 'postulado político', comum aos diversos países economicamente desenvolvidos. Isto explica, de um lado, que a protecção ao consumidor e a sua problemática passassem a ser tratadas de um modo geral, global e sistemático, e que, por outro, fosse crescente o empenhamento consciente na matéria dos órgãos legiferantes."Deste empenhamento tem resultado, nos últimos anos, abundante legislação avulsa ou extravagante, leis especiais, regulamentos, normas técnicas de qualidade e segurança cujo objecto directo e específico é a proteç̧ão do consumidor, assim alcandorada a impressivo vector da política legislativa contemporânea e a princípio do pensamento jurídico moderno. É o que vamos mostrar, não sem que primeiro se refiram as razões da temática ímpar e moderna que é a tutela do consumidor, "exigência do nosso tempo e dos mais actuais temas político-jurídicos internacionais', no dizer de Eike Von Hipel"

Adiante o autor complementa: "A intervenção estadual deve muito ao movimento dos consumidores (consumerism) que iniciado nos Estados Unidos da América, se propagou à Europa a partir dos anos sessenta. Despertando da sua letargia e aproveitando a liberdade de associação, agora amplamente reconhecida, o consumidor resolve pôr termo à inércia e desorganização que o isolavam e o tornavam mais débil perante o produtor, dotado de organização e informação poderosas. Para se defender, e defender não só os interesses individuais como os interesses comuns ou difusos contra os abusos do produtor e do distribuidor, o consumidor passa a agir sob diversas formas, desde os movimentos de cariz espontâneo à organização de associações, e a multiplicar os escritos, as transmissões radiofónicas e televisivas e os debates públicos dedicados à sua causa. O impacto desta acção na opinião pública, cada vez mais favorável à ideia de bem-estar individual e social que norteia o 'consumerismo', e o poderio das suas associações tornaram-no progressivamente mais simpático (everybody is consumer) e converteram-no numa força, num grupo de pressão que os produtores e os profissionais em geral não puderam mais ignorar.

Daí o aparecimento dos organismos de defesa dos consumidores, que tanto resultam da livre iniciativa (autotutela) como do impulso do Estado. Nos primeiros - organismos de direito privado - salientam-se as cooperativas de consumo, precursoras do movimento, e as associações de consumidores. Nos segundos organismos de direito público - são correntes os organismos consultivos da Administração Pública, chegando mesmo a existir, em certos casos, um departamento governamental para o consumo, a fim de evitar que a diversidade de organismos espalhados pelos vários departamentos reduza a eficácia da proteç̧ão desejada. A existência de um Instituto Nacional de Consumo é também frequente." (SILVA, João Calvão da. Responsabilidade civil do produtor. Coimbra: Almedina, 1999. p. 30-40).
} 
Como visto anteriormente, a defesa do consumidor encontra amparo constitucional. Não obstante, há a proteção infraconstitucional. Nos termos do inciso II do artigo $4^{\circ}$ do CDC a ação governamental efetivamente protege o consumidor, por meio da iniciativa direta, por incentivos à criação e desenvolvimento de associações representativas, pela presença do Estado no mercado de consumo e pela garantia dos produtos e serviços com padrões adequados de qualidade, segurança, durabilidade e desempenho.

$\mathrm{O}$ artigo 105 do diploma consumerista estabelece que a proteção e defesa do consumidor serão feitas pelos órgãos federais, estaduais, do Distrito Federal e municipais. Vale lembrar que cabe ao Estado a manutenção de assistência jurídica, integral e gratuita para o consumidor carente. De fato prestam esse serviço a Defensoria Pública e Procons, bem como, no âmbito do Ministério Público, as Promotorias de Justiça de Defesa do Consumidor.

A obrigatoriedade de ingerência do Estado nas relações de consumo advém de alguns princípios e diretrizes, os quais ratificam as ações interventistas estatais como uma das principais formas de proteção do consumidor. ${ }^{51}$ Da mesma forma, é obrigação do

\footnotetext{
${ }^{51}$ Renato Moreira Dorneles elucida que: "Assim, todo e qualquer delito ou prática infrativa realizados no mercado de consumo deve ter por parte do Estado brasileiro, ação ou reação, capaz de prevenir possíveis lesões aos direitos dos consumidores ou repreender os fornecedores pela prática de atos danosos. É o que se pretende com o Código Brasileiro de Defesa do Consumidor, onde está explicitado dentre os princípios fundamentais da Política Nacional de Relações de Consumo: 'a coibição e repressão eficientes de todos os abusos praticados', pela presença do Estado no mercado de consumo", tudo visando à proteção efetiva dos consumidores.

Entretanto, a natureza jurídica conferida às normas consumeristas no Brasil e consubstanciadas no Código de Defesa do Consumidor, de per si, não trouxe ao Sistema Brasileiro de Defesa do Consumidor a possibilidade efetiva de resultados positivos aos consumidores em geral. Somente após a edição do Dec. Federal 2.181, de 20.03.1997, conforme já tratamos anteriormente (quando abordamos a evolução legislativa em matéria consumerista no Brasil), foi que isto passou a ser possível. Nesse sentido, os arts. $4^{\circ}$ e $5^{\circ}$ do Dec. Federal 2.181/97 conferem aos entes que atuam na tutela administrativa dos consumidores o chamado poder de polícia administrativa, externado nas ações fiscalizatórias e na possibilidade de instauração de processo administrativo para apuração de práticas infrativas contra os consumidores (arts. 33 e seguintes do Dec. Federal 2.181/97).

Com efeito, o art. $4^{\circ}$ do $\mathrm{CDC}$, na medida em que autoriza os órgãos da administração pública, federal, municipal, destinados à defesa do consumidor, a fiscalizar as relações de consumo e a instaurar expedientes administrativos para a investigação e punição das práticas infrativas realizadas no mercado, tem como resultado garantir a defesa não simplesmente daquele consumidor prejudicado (considerado individualmente), mas a de uma coletividade de consumidores. Tudo isto, sempre se tendo em vista o princípio insculpido no Código de Defesa do Consumidor, do 'reconhecimento da vulnerabilidade do consumidor no mercado de consumo.

O Código Brasileiro de Defesa do Consumidor prevê em seu art. 105, que trata do Sistema Nacional de Defesa do Consumidor, que a proteção e defesa dos consumidores será exercida por órgãos federais, estaduais, do Distrito Federal e municipais, além das entidades privadas de defesa do consumidor. Como instrumentos desse Sistema, o art. $5^{\circ}$ do CDC, a seu tempo, enumera aqueles com os quais contará o Poder Público (Estado) para a execução da Política Nacional de Relações de Consumo.' (DORNELES, Renato Moreira. A intervenção estatal brasileira nas relações de consumo: estrutura legislativa e fundamentos. Revista de Direito do Consumidor, São Paulo, n. 54, p. 68, abr./jun. 2004).
} 
Estado incentivar a criação e o desenvolvimento de associações de defesa de consumidores a fim de facilitar o atendimento ao consumidor necessitado.

A atuação do controle administrativo é intensa e feita por vários órgãos, notadamente na proteção do consumidor, em algumas hipóteses com legitimidade ${ }^{52}$ para propor ação de controle abstrato das cláusulas abusivas e ações coletivas de defesa de interesses individuais homogêneos. ${ }^{53} \mathrm{Com}$ efeito, os órgãos oficiais de defesa do consumidor são relevantes na solução de conflitos, quer na atuação preventiva, mediante orientação e resposta a consultas ou quer na repressiva, no caso de abusos e fraudes.

Percebe-se que a atuação estatal, ainda que deficiente é feita nas esferas federal, estadual e municipal e o Poder Executivo é responsável pela fiscalização das normas. ${ }^{54} \mathrm{Da}$ mesma forma, o Ministério Público também tem o dever de proteger os interesses difusos e coletivos, nos termos do inciso III do artigo 129/CF.

\section{O papel exercido pela Administração Pública é fundamental, tanto no processo} produtivo quanto na comercialização dos produtos, adotando medidas de segurança e

\footnotetext{
${ }^{52} \mathrm{O}$ seguinte acórdão dá a legitimidade ao Ministério Público: “Ação civil pública - Cobrança antecipada e reajuste das mensalidades escolares - Legitimidade ativa ad causam do Ministério Público. 1. As Turmas que compõem a $2^{\mathrm{a}}$ Seção deste Tribunal são competentes para decidir questões relativas a reajustes de mensalidades escolares por estabelecimentos de ensino particulares. Precedentes da Corte Especial. 2. O Ministério Público tem legitimidade ativa para propor ação civil pública para impedir a cobrança antecipada e a utilização de índice ilegal no reajuste das mensalidades escolares, havendo, nessa hipótese, interesse coletivo definido no art.81, [parágrafo único] inciso II, do Código de Defesa do Consumidor. 3. A atuação do Ministério Público justifica-se, ainda, por se tratar de direito à educação, definido pela própria Constituição Federal como direito social. 4. Recurso especial conhecido e provido. (STJ - 3 ${ }^{\mathrm{a}}$ T. - REsp 138.583/SC - rel. Min. Carlos Alberto Menezes Direito - j. 06.08.1998).

${ }^{53}$ Antônio Camargo Ferraz, Édis Milaré e Nelson Nery Junior ressaltam a importância da tutela do consumidor em interesses difusos em geral e do consumidor em particular: "O surgimento dos grandes conglomerados urbanos, das metrópoles, a explosão demográfica, a revolução industrial, o desmesurado desenvolvimento das relações econômicas, com a produção e consumo de massa, o nascimento de cartéis, holdings, multinacionais e das atividades monopolísticas, a hipertrofia da intervenção do Estado na esfera social e econômica, o aparecimento dos meios de comunicação de massa e, com eles, o fenômeno da propaganda maciça, entre outras coisas, por terem escapado do controle do homem, muitas vezes voltaramse contra ele próprio, repercutindo de forma negativa sobre a qualidade de vida e atingindo inevitavelmente os interesses difusos. (FERRAZ, Antônio Camargo; MILARÉ, Édis; NERY JÚNIOR, Nelson. Ação civil pública: aspectos sócio-jurídicos de sua imprescindibilidade. São Paulo: Ed. Revista dos Tribunais 2006).

${ }^{54}$ João Batista de Almeida traz à tona o problema do Brasil no que concerne à fiscalização: "As dimensões territoriais do Brasil impedem que os órgãos fiscalizadores federais estejam presentes em todos os Municípios brasileiros; por vezes até nas Capitais o atendimento é deficiente. Os órgãos estaduais quase sempre padecem do mesmo vício. E os órgãos municipais, quando existem, são vitimados pela inércia, por falta de condições técnicas, pessoal habilitado e recursos financeiros. Conclusão: a fiscalização não funciona como deveria funcionar."

Adiante sugere a mudança estrutural para que a fiscalização estatal seja mais eficiente e abranja todo o território brasileiro: "A recomendação que se faz para que se reverta essa situação é o estabelecimento de convênios em todos os níveis, de tal forma que os órgãos estaduais e municipais possam exercer funções típicas dos órgãos federais, arcando as entidades de melhor nível técnico com a preparação técnica do pessoal da linha de frente da fiscalização. A descentralização, mesmo sob forma de convênio, é o melhor caminho para superar o entrave do gigantismo estrutural e territorial." (ALMEIDA, João Batista de. op. cit., p. 323).
} 
padrões de qualidade tendentes a realizar a função preventiva de danos acidentais que se multiplicam com a produção em massa.

A agência de vigilância sanitária, por exemplo, controla e fiscaliza os produtos e serviços que podem colocar em risco a saúde pública. De fato, a função exercida pela Anvisa, Agência Nacional de Vigilância Sanitária, tem sido cada vez mais importante, uma vez que o fluxo de pessoas entre os países aumentou significativamente e na mesma proporção as doenças infecciosas, as quais, não respeitam fronteiras geográficas. ${ }^{55}$

De fato, retraiu-se a presença direta do Estado no domínio econômico para dar lugar ao aspecto regulatório, as agências reguladoras, sendo o principal papel a normatização conjuntural de cada setor regulado e a fiscalização do comportamento das empresas, diz-se que há um Estado-regulador, que atua sobre o mercado, ao invés do Estado-empresário.

A Anvisa, pela Resolução da Diretoria Colegiada RDC nº 205/2006, dispõe sobre o uso de aditivos e coadjuvantes de tecnologia em alimentos, com vistas a minimizar os riscos à saúde humana.

Por exemplo, nesse regulamento, alimento ficou definido como toda substância que se ingere no estado natural, elaborada ou semi-elaborada, destinada ao consumo humano, incluídas as bebidas e qualquer outra substância utilizada em sua elaboração, preparo ou tratamento, excluídos os cosméticos, o tabaco e as substâncias utilizadas unicamente como medicamentos.

Os aditivos alimentares serão submetidos à revisão periódica, podendo seu emprego ser proibido desde que nova concepção científica ou tecnológica modifique convicção anterior quanto à sua inocuidade ou aos seus limites de tolerância.

\footnotetext{
${ }^{55}$ A Anvisa tem por finalidade segundo o artigo $6^{\circ}$ da Lei $n^{\circ}$ 9.782/99: "A Agência terá por finalidade institucional promover a proteção da saúde da população, por intermédio do controle sanitário da produção e da comercialização de produtos e serviços submetidos à vigilância sanitária, inclusive dos ambientes, dos processos, dos insumos e das tecnologias a eles relacionadas, bem como o controle de portos, aeroportos e de fronteiras."

O artigo 42 prevê que: "O artigo 57 do Decreto-Lei no 986, de outubro de 1969 passa a vigorar a seguinte redação: "A importação de alimentos, de aditivos para alimentos e de substâncias destinadas a serem empregadas no fabrico de artigos, utensílios e equipamentos destinados a entrar em contato com alimentos, fica sujeita ao disposto neste Decreto-lei e em seus Regulamentos sendo a análise de controle efetuada por amostragem, a critério da autoridade sanitária, no momento de seu desembarque do país."

Tal Decreto-Lei estabelece a obrigatoriedade de registro dos alimentos expostos ao consumo: "Art. $3^{\circ}$ Todo alimento somente será exposto ao consumo ou entregue à venda depois de registrado no órgão competente do Ministério da Saúde.

$\S 1^{\circ} \mathrm{O}$ registro a que se refere este artigo será válido em todo o território nacional e será concedido no prazo máximo de 60 (sessenta) dias a contar da data da entrega do respectivo requerimento, salvo os casos de inobservância dos dispositivos deste Decreto-Lei e de seus regulamentos."
} 
Nota-se que a agência reguladora tem por finalidade suprir as deficiências do mercado e a regulação se exterioriza como forma de ampliação do controle-fiscalização, sendo decorrência direta e imediata da ampliação do controle-regulação. ${ }^{56}$

Por outro lado, a partir do momento em que o Governo exerce algum controle sobre o consumo, estará indiretamente determinando o que o consumidor deve ter, podendo limitar a liberdade de escolha dos consumidores, na medida em que existem normas que regulam a produção e a venda de artigos. ${ }^{57}$

\subsubsection{Da evolução da responsabilidade do Estado}

Nessa seara, questiona-se se o Estado não cumpre um dever de fiscalizar, caracteriza-se a omissão e, portanto, pode ser responsabilizado.

\footnotetext{
${ }^{56}$ Marçal Justen Filho ressalta que: "Quanto maiores os constrangimentos e menor a margem de liberdade dos agentes econômicos devem não só buscar objetivos delimitados pelo Estado, mas também cumprir as formalidades destinadas a comprovar a correção de sua conduta. O Estado exige que os particulares tornem sua atuação muito mais transparente não apenas em face dos controles burocráticos estatais, mas também perante a comunidade em seu todo. Essa transparência já era aplicada na sistemática anterior, quando se tratava de prestação de serviços públicos pelos particulares, em nome e risco próprios (concessão ou permissão de serviços públicos). Mas é ampliada grandemente, inclusive admitindo-se a fiscalização através da participação de entidades representativas dos usuários e da comunidade em seu todo." (JUSTEN FILHO, Marçal. O direito das agências reguladoras independentes. São Paulo: Dialética, 2002. p. 30).

${ }^{57}$ Teresa Ancona Lopez com acuidade observa que: "A intromissão do Estado na vida privada, ocupando o lugar da família e tentando resultados que a família não conseguiu, vem criar uma sociedade de eternas crianças que não se responsabilizam pelas próprias escolhas e, enfim, não assumem os danos resultantes dos próprios atos, no uso de sua autonomia. O Estado, na sempre precisa lição de Tércio Ferraz Jr., não pode degradar o ser humano à condição de incapaz de discernimento entre o bem e o mal. O Estado tutor reduz o cidadão à condição dos que 'não sabem o que fazem', adultos infantilizados, sujeitos à imposições e manobras do poder, arremata o jurista.

(...)

Ao superproteger os cidadãos, o Estado jogou toda a responsabilidade pelos males que ocorrem na sociedade sobre aqueles que exercem atividades produtivas, lançam novas descobertas e produtos no mercado, enfim, sobre aqueles entes que fazem girar a economia dos países, isto é, as empresas. Com essa política está o Estado a dizer: podem abusar do álcool, dos remédios, dos refrigerantes, das bebidas, do chocolate, do fumo e de tudo mais, pois o poder público estará pronto a condenar em ações indenizatórias todos os fornecedores de produtos e serviços.

Infelizmente, essa postura política pode gerar, pelo menos três consequiências perversas. Ou seja, tendo as empresas que responder quase sempre pelos atos dos cidadãos - crianças pode ser que acabem tomando menos precauções do que as necessárias para evitar o dano; cumprem a lei e pronto; ou, ainda, haverá elevação do preço dos produtos por conta das indenizações futuras ou do pagamento do seguro de responsabilidade civil; e, a pior dessas conseqüências nesfastas é a possível falta de cuidado ou diligência dos consumidores no uso dos produtos prejudiciais à saúde, tendo em vista sua irresponsabilidade e a certeza de um lucro certo com a verba indenizatória.

Em suma, não podemos nos ajoelhar diante do "Grande Irmão" e fazer desaparecer o poder de escolher conscientemente o que nos dá prazer na vida, mesmo que esse prazer possa pôr em risco nossa saúde. É no uso de nosso livre-arbítrio que nos afirmamos como cidadãos. Aqui cabe a sempre lúcida lição Hannah Arendt: "quem quer que queira educar adultos na realidade pretende agir como guardião e impedi-los de atividade política." (op. cit., p. 17-18). LOPEZ, Teresa Ancona. Nexo causal e produtos potencialmente nocivos: a experiência brasileira do tabaco. São Paulo: Quartier Latin, 2008.
} 
Inicialmente, não se discutia responsabilidade do Estado. A justificativa para a fase da irresponsabilidade era que o Estado fazia o Direito, e por fazê-lo, por dizê-lo e por estar soberanamente acima dos súditos, seria uma contradição vir a ser considerado culpado e ter de indenizar o particular por um ato contrário ao Direito. ${ }^{58}$

Carlos Alberto Dabus Maluf lembra que desde o surgimento da noção de Estado e mesmo nos primórdios do Estado moderno, vigorava a tese da absoluta irresponsabilidade do Estado pelos danos decorrentes de sua atuação. ${ }^{59}$

\footnotetext{
${ }^{58} \mathrm{Em}$ decisão interessante que relata justamente a evolução da responsabilidade civil do Estado na época da ditadura: " A Administração Pública, na qualidade de sujeito de direitos, quando causar prejuízos ou danos deve arcar com a obrigação de ressarcí-los, desde que decorrentes de sua ação ou mesmo de sua abstenção. A evolução desse conceito partiu da aceitação da irresponsabilidade do Estado até atingir a responsabilidade objetiva, ou seja, aquela que independe de culpa para sua caracterização.

Mesmo no campo do direito privado, a adoção de critérios objetivos para a responsabilidade por danos causados a terceiros demonstrou lento caminhar onde avultou o trabalho de grandes doutrinadores.

Inegavelmente, foi na França que se consolidou o campo mais propício de expansão da tese de responsabilidade objetiva. Como ferrenhos e precursores defensores dessa teoria destacam-se Josserand e Saleilles.
}

(...)

Josserand sustentava, porém, a responsabilidade objetiva como fundamento que deveria coexistir com o princípio clássico da culpa; segundo suas idéias, a responsabilidade moderna se situava entre dois polos: o pólo objetivo, do risco criado; e o subjetivo, onde se cogitava da culpa.

SAVATIER, de igual forma, admitia as duas formas de responsabilização, contudo, para ele o risco ocupava caráter subsidiário ao lado da culpa: a responsabilidade civil estribada na culpa subjetiva na regra geral, ordinária: a responsabilidade objetiva, a exceção.

(...)

No campo específico do direito público, sob o domínio de governos absolutos, vigia o princípio da irresponsabilidade do Estado, como decorrência do fato de o soberano não poder causar males e seus subordinados - "Le roi ne peut mal faire" ou na regra inglesa de infalibilidade "The king can do no wrong" - .

Embora esse princípio, por vezes, pudesse ser suavizado, difícil a eventual caracterização da responsabilidade dos funcionários por comportamento seu, uma vez que era dependente de autorização de órgão superior que raramente a concedia.

Tal irresponsabilidade vem desde o Estado Romano, estendendo-se pela época medieval, quando o senhor feudal não respondia pelos danos sofridos pelos seus subordinados; evidentemente, vigorou nos estados absolutistas pois o soberano agia conforme seus desígnios em nome de Deus.

Mesmo em Estados contemporâneos, essa teoria foi aceita na Inglaterra e nos Estados Unidos; num pela simples razão de que o rei não podia ser submetido a nenhum processo, vez que inexistia poder a ele superior; noutro, o fundamento era de que o Estado não poderia ser julgado por um dos seus órgãos.

Atualmente, essa doutrina se encontra, totalmente superada, pois mesmo esses países já a abandonaram por meio do "Federal Cort Claime Act" (1946) e do "Crown Proceding Act" (1947), respectivamente, Estados Unidos e Inglaterra.

(...)

O marco relevante para o reconhecimento de responsabilidade, mesmo à falta de texto legislativo, foi indubitavelmente o aresto Blanco, do Tribunal de Conflitos, quando se fixou a necessidade de regras especiais, afastadas do Código Civil e das relações entre particulares:

(...)

A partir daí entendeu-se que as regras aplicáveis à matéria são aquelas próprias do direito público, o que proporcionou sensível progresso a respeito, especialmente no direito francês que foi precursor em rejeitar os dispositivos do Código Civil para resolver problemas a ele estranhos.

(Ação ordinária nº 1298666, juiz jorge Tadeo Flaquer Scartezzini, j. 17/12/1980)

${ }^{59}$ MALUF, Carlos Alberto Dabus. Responsabilidade civil e sua repercussão nos tribunais. Coord. Regina Beatriz Tavares da Silva. São Paulo: Saraiva, 2008. p. 37. 
Nessa fase eram adotadas as máximas "The king can do no wrong" ou "le roi ne peut mal faire", mas ainda assim era temperada, em suas consequências gravosas, quando o ato lesivo pudesse ser diretamente relacionado a um comportamento pessoal, seu. Mas na França a responsabilização dos funcionários por atos culposos perante os Tribunais Civis dependia de prévia autorização do Conselho de Estado francês, o qual raramente a concedia.

$\mathrm{Na}$ verdade, o reconhecimento da responsabilidade do Estado, à margem de qualquer texto legislativo e segundo princípios de Direito Público, teve por marco relevante o caso Blanco. Em 1873, o Conselho de Estado derrogou a colocação privatística fundamentada nas disposições do Código Napoleônico ao decidir que o Estado é civilmente responsável por prejuízos ocasionados a terceiros, ao indenizar a menina Agnes Blanco, ao ter suas pernas amputadas, por ter sido atingida por um trem.

Essa decisão representou papel importante para reconhecer a responsabilidade do Estado mesmo à falta de lei. Percebeu-se a tendência da responsabilidade do Estado em expandir-se.

No Brasil, a teoria da irresponsabilidade nunca foi adotada, pois as Constituições de $1824^{60}$ e a de $1891^{61}$ não continham a isenção de responsabilidade do Estado. Ao contrário, previam, de modo expresso, a responsabilidade do funcionário e o empregado público. Havia, apenas, leis ordinárias assinalando a responsabilidade solidária do Estado com o agente causador do dano.

A ideia do Estado é uma consequência lógica inevitável da noção de Estado de Direito, da submissão do Poder Público ao Direito.

Após a teoria da irresponsabilidade, surgiu a distinção doutrinária entre os atos de império e os atos de gestão. Nessa esteira, o Estado não responderia pelos danos que causasse na prática de atos de império. Quando o Estado estivesse no exercício de sua soberania, havia ainda um resquício da teoria da irresponsabilidade. Por sua vez, os atos de

\footnotetext{
${ }^{60}$ Constituição de 1824: “Art.179. A inviolabilidade dos Direitos Civis, e Políticos dos Cidadãos Brazileiros, que tem por base a liberdade, a segurança individual, e a propriedade, é garantida pela Constituição do Império, pela maneira seguinte. (...) XXIX - Os Empregados Públicos são estrictamente responsaveis pelo abusos, e omissões praticadas no exercício das suas funções, e por não fazerem effectivamente responsaveis aos seus subalternos."

${ }^{61}$ Constituição de 1891: “Art.82. Os funcionários publicos são estrictamente responsaveis pelos abusos e omissões em que incorrerem no exercício de seus cargos, assim como pela indulgencia, ou negligencia em não responsabilisarem effectivamente os seus subalternos. Paragrapho único. O funccionario publico obrigar-se-ha por compromisso formal, acto da posse, ao desempenho dos seus deveres legaes."
} 
gestão eram aqueles que se aproximavam aos atos de direito comum, do direito privado. Nessas hipóteses caberia responsabilização por danos eventualmente causados a terceiros.

Apesar da evolução e do Estado não ser mais considerado acima do bem e do mal, a divisão feita tornava difícil, se não impossível distinguir os atos de império dos atos de gestão.

Adota-se uma regra do direito privado, a responsabilidade subjetiva do agente. A responsabilidade do Estado surgiria, sempre, em decorrência da conduta culposa identificada de agente seu. A vítima teria o ônus de demonstrar a culpa de um determinado agente do Estado: precisaria apontar o causador do dano e, isto demonstrado, o Estado responderia pela atitude culposa do seu agente.

Surgiu a noção de que o Estado deveria responder, na forma do direito privado, tal qual o patrão respondia por atos de seus empregados. Essa teoria deu ensejo ao surgimento do art. $15^{62}$ do Código Civil de 1916, que disciplinava a responsabilidade do Estado, fixando regra subjetiva, ou seja, a exigir na sua interpretação literal pelo menos a identificação da culpa do funcionário.

Contudo, na forma como foi redigido, deixa claríssima a intenção de exigir da vítima o apontamento do agente culposo. Há que se ressaltar que o artigo 15 do CC/1916 falava em procedimento contrário ao direito ou faltando a dever prescrito por lei; portanto, o dispositivo condicionava o dever de indenizar à perquirição de culpa do representante. Outro aspecto a ser indicado é que a responsabilidade decorreria por atos dos representantes que nessa qualidade causassem danos a terceiros.

Ainda com relação ao dispositivo em questão, é com relação ao direito regressivo contra os causadores do dano que inclusive se repete na Constituição atual, acrescida dos requisitos de dolo ou culpa.

No sentido de prescindir da demonstração da culpa específica do agente para se obter a indenização evoluiu a responsabilidade do Estado.

Nessa fase bastava comprovar o mau funcionamento do serviço, ainda que fosse impossível indicar o agente causador do dano. Essa noção é denominada pelos franceses de faute $d u$ service, que causou dúvidas em sua tradução, porque alguns a entendem como

\footnotetext{
${ }^{62}$ Art.15. As pessoas jurídicas de direito público são civilmente responsáveis por atos dos seus representantes que nessa qualidade causem danos a terceiros, procedendo de modo contrário ao direito ou faltando a dever prescrito por lei, salvo o direito regressivo contra os causadores do dano."
} 
falta, o que levaria a idéia de algo objetivo, há ainda quem interprete como falha ou ainda como culpa do serviço.

Em inúmeros casos de responsabilidade por faute du service, haverá de ser admitida uma "presunção de culpa", pena de inoperância desta modalidade de responsabilização ante a extrema dificuldade de demonstrar que o serviço operou abaixo dos padrões devidos. Afirma ainda que essa presunção não elide o caráter subjetivo desta responsabilidade, pois se o Poder Público demonstrar que se comportou com diligência, perícia e prudência, antítese da culpa, estará isento da obrigação de indenizar.

A culpa do serviço ocorreria em três situações ${ }^{63}$ : quando o serviço não funcionasse, no caso de omissão do Estado; quando o serviço funcionasse mal, funcionamento defeituoso, inadequado ou quando o serviço funcionasse extemporaneamente, atrasado, causando dano.

Essa teoria norteou a interpretação do art.15 do CC/1916 e foi, para muitos doutrinadores e aplicadores do Direito, a regra adotada para casos de responsabilidade civil do Estado em razão de atos omissivos.

Como o Estado Moderno acolhe o princípio da igualdade de todos perante a lei, forçosamente há de se aceitar injurídico o comportamento estatal que agrave desigualmente a alguém, ao exercer atividades no interesse de todos. Quem diz Direito, diz responsabilidade.

Sem se abandonar a teoria da culpa anônima ou administrativa, aplica-se essa nas hipóteses decorrentes, sobretudo nas atividades de risco, mas não apenas porque também haverá responsabilidade da Administração nos danos advindos por atividade lícita.

Jean Rivero distingue a responsabilidade objetiva por risco, em acidentes de trabalho sofridos por agentes da Administração e danos causados de responsabilidade sem qualquer culpa ou deficiência do serviço, mas que não procedem do risco administrativo e danos por atividade lícita em que também cabe responsabilidade objetiva do Estado. (Ex : danos decorrentes de obras públicas não perigosas, medidas de ordem econômica ou social impostas a uma empresa em nome do interesse geral). ${ }^{64}$

\footnotetext{
${ }^{63}$ A tripartição originou-se em obra de Paul Duez, que faz expressa menção à culpa, recorrendo a expressões latinas culpa in committendo, culpa in ommittendo.

${ }^{64}$ RIVERO, Jean. Direito administrativo. Coimbra: Almedina, 1981.
} 
Essa teoria tem por fundamento o princípio da igualdade dos ônus e encargos sociais, significando que se dividem, por todos, os prejuízos causados pelo Estado, porque, da mesma forma, por toda a população é repartido o benefício que o Estado proporciona, principalmente quando se está diante de um comportamento lícito, que causa danos. Já no comportamento ilícito comissivo ou omissivo, o dever de reparar o dano é a contrapartida do princípio da legalidade. Porém, no caso de comportamentos ilícitos comissivos, o dever de reparar já é imposto pelo princípio da igualdade.

Esse princípio pode ser também denominado de isonomia ou de solidariedade social. A responsabilidade objetiva é assim denominada porque prescinde de qualquer verificação de índole subjetiva, e afasta-se da perquirição da culpa.

Doutrina e jurisprudência, preponderantemente, afirmam a responsabilidade objetiva do Estado como regra do nosso sistema, desde a Constituição de $1946^{65}$, e as de 1967, 1969 e 1988. A vigente apresentou duas importantes evoluções. Uma delas é o reconhecimento daquilo que a doutrina e jurisprudência majoritariamente já admitiam, que a pessoa jurídica de direito privado, prestadora de serviço público, respondesse por responsabilidade objetiva, sob a mesma forma que a pessoa jurídica de direito público. A outra evolução foi a amplitude interpretativa permitida pelo uso do termo "agente", pois a Constituição de $1967^{66}$ valia-se do vocábulo "funcionário", que abrange uma gama específica dos personagens envolvidos.

Lucia Valle Figueiredo fala em dever concreto de atuação e não de um dever abstrato, pois se a idéia da responsabilidade objetiva adveio do princípio da repartição dos ônus e encargos públicos, é de se exigir que o dano suportado pelo administrado não seja derivado de situação normalmente compartilhada por todos na sociedade. Daí falar-se em dever concreto de atuação propiciador do surgimento do nexo causal. Para exemplificar, a doutrinadora diz que o risco de assalto nas grandes cidades é infelizmente ônus suportado por todos os cidadãos, não ensejando, em princípio, responsabilidade do Estado.

\footnotetext{
65، Art.194. As pessoas jurídicas de direito público interno são civilmente responsáveis pelos danos que os seus funcionários, nessa qualidade, causem a terceiros. Parágrafo único: Caber-lhes-á ação regressiva contra os funcionários causadores do dano, quando tiver havido culpa destes'

66،Art.107: As pessoas jurídicas de direito público responderão pelos danos que seus funcionários, nessa qualidade, causarem a terceiros. Parágrafo único: Caberá ação regressiva contra o funcionário responsável, nos casos de dolo ou culpa"
} 


\subsubsection{Da omissão do Estado}

A responsabilidade do Estado pode ser genericamente identificada em duas vertentes: decorrente do próprio comportamento do Estado, gerador do dano; oriunda de uma omissão, originada pela inobservância do dever de evitar o dano.

Sem embargo, a responsabilidade do Estado governa-se por princípios próprios compatíveis com a peculiaridade de sua posição jurídica, e, por isso, é mais extensa que a responsabilidade que pode calhar às pessoas privadas.

Renato Alessi assinala que só cabe falar em responsabilidade, propriamente dita, quando alguém viola um direito alheio. Se não há violação, mas apenas sacrifício de direito, previsto e autorizado pela ordenação jurídica, não se discute o tema responsabilidade do Estado. ${ }^{67}$

Com efeito, se o interesse público para ser satisfeito depende de um sacrifício de um interesse privado, obviamente, em virtude da supremacia do interesse público, o direito privado será sacrificado. Estabelece-se dever de indenizar aquele cujo direito foi sacrificado a fim de realizar-se um interesse maior. Opera-se a conversão do direito atingido em sua equivalente expressão patrimonial.

Roberto Dromi ressalta que controle, responsabilidade e proteção se completam reciprocamente:

"El Estado debe ser responsable. Ahora bien, la responsabilidad es idílica e ilusoria, si no se tienen técnicas y organismos eficaces de control. Control, responsabilidad y protección se predican recíprocamente. Sin el uno no hay el otro. Sin control no hay responsabilidad y si no hay responsabilidad las medidas de protección social son falaces, venimos diciendo desde hace tiempo en nuestro ensayo "Constitución, Gobierno y Control." 68

Esclarece Celso Antônio Bandeira de Mello:

"O interesse público, fixado por via legal, não está à disposição da vontade do administrador, sujeito à vontade deste; pelo contrário,

\footnotetext{
${ }^{67}$ ALESSI, Renato. Principi di diritto amministrativo. Milano: Giuffrè, 1971. v. 1.

${ }^{68}$ Em tradução livre o Autor assevera que: “O Estado deve ser responsável. Ora, a responsabilidade é idílica e ilusória, se não houver técnicas e organismos eficazes de controle. Controle, responsabilidade e proteção se qualificam reciprocamente. Sem um não há o outro. Sem controle não há responsabilidade e se não há responsabilidade as medidas de proteção social são falácias, temos dito há algum tempo em nosso ensaio" DROMI, Roberto. Derecho administrativo. Buenos Aires: Ciudad Argentina, 2001. p. 42-43.
} 
apresenta-se para ele sob a forma de um comando. Por isso mesmo a prossecução das finalidades assinaladas, longe de ser um "problema pessoal' da Administração, impõe-se como obrigação indiscutível. Como a atividade administrativa é de caráter serviente, coloca-se uma situação coativa: o interesse público, tal como foi fixado, tem que ser prosseguido, uma vez que a lei assim determinou. Daí a obrigação de as pessoas administrativas prosseguirem o próprio escopo, característica tão realçada pelos autores." ${ }^{69}$

Para o autor, a responsabilidade decorreria do descumprimento do dever legal de obstar o evento lesivo. Só caberia responsabilização na hipótese de estar obrigado a impedi-lo; se o Estado não agiu, conclui que não pode ser autor do dano.

Em suas palavras: "se o Estado devendo agir, por imposição legal, não agiu o fez deficientemente, comportando-se abaixo dos padrões legais que normalmente deveriam caracterizá-lo, responde por esta incúria, negligência ou deficiência, que traduzem um ilícito ensejador do dano não evitado quando, de direito, devia sê-lo.”

Gustavo Tepedino, por sua vez, defende a total superação da regra infraconstitucional e, consequentemente, a adoção exclusiva da teoria objetiva para a responsabilidade civil do Estado: "não é dado ao intérprete restringir onde o legislador não restringiu, sobretudo em se tratando de legislador constituinte. A Constituição Federal, ao introduzir a responsabilidade objetiva para os atos da Administração Pública, altera inteiramente a dogmática da responsabilidade neste campo, com base em outros princípios axiológicos e normativos (dos quais se destaca o da isonomia e o da justiça distributiva)" ${ }^{\text {,70. }}$.

Marçal Justen Filho assevera que para o Estado há:

"o dever de evitar a prática de certas ações, pois contrárias ao direito ou a valores fundamentais.". E no tocante a atos omissivos esclarece: "Já nos atos omissivos, é necessário estabelecer uma distinção. Existem hipóteses em que o direito impõe ao Estado o dever de agir. Assim, imagine-se uma regra estabelecendo o dever de o Estado interditar o estabelecimento comercial que não tiver autorização de funcionamento. Nesses casos, a situação jurídica é similar à atuação de natureza comissiva. Deixar de agir quando a lei manda que o sujeito aja é juridicamente equivalente a agir quando a lei proíbe a ação. Num caso, a lei diz:'é proibido fazer'; noutro, estabelece:"é obrigatório fazer'. A conduta que infringe o dever, no primeiro caso, consiste numa ação; no segundo é uma omissão" 71 .

\footnotetext{
${ }^{69}$ MELlO, Celso Antônio Bandeira de. Curso de direito administrativo. 21. ed. São Paulo: Malheiros, 2006. p. 69.

${ }^{70}$ TEPEDINO, Gustavo. Temas de direito civil. 3. ed. Rio de Janeiro: Renovar, 2004.

${ }^{71}$ JUSTEN FILHO, Marçal. Curso de direito administrativo. São Paulo: Saraiva, 2005. p. 801.
} 
De fato, com o advento da Constituição de 1946, discutia-se na doutrina se a responsabilidade civil do Estado prevista no artigo 15 do CC de 1916 continuava em vigor, ou se o artigo 194 havia revogado. ${ }^{72}$

Segundo Celso Antônio e Maria Sylvia Zanella di Pietro, o artigo 15 prevaleceu para as hipóteses de responsabilidade do Estado por ato omissivo, aplicando-se a regra constitucional apenas para os atos comissivos. Assim, para essa parte da doutrina, o artigo $37, \S 6^{\circ}$, da atual Constituição, o Estado deve indenizar nos casos de atos comissivos, nos quais a obrigação pressupõe apenas 2 requisitos: o dano, a lesão a interesse juridicamente tutelado e o nexo causal. Enquanto nos casos de atos omissivos aplicar-se-ia a regra da responsabilidade subjetiva, dano, nexo e culpa, esta última seria mitigada, pois não precisaria estar personificada em um ou mais servidores determinados, bastando que se comprovasse a ineficiência culposa do serviço público, culpa anônima. Os que adotam essa posição têm o convincente argumento de que o Estado não pode ser responsável por tudo o que acontece, o grande segurador de todas as desgraças e infortúnios. É possível afirmar-se que o sistema de responsabilidade do Estado não é único, a regra constitucional não se mostra isolada, mas enseja, ao contrário, um sistema misto de responsabilidade.

Se a Administração Pública não cumpriu a sua função de munus público, ou seja, não fiscalizou determinado produto, previamente autorizado, e ainda assim a Administração for surpreendida, indaga-se se o risco do desenvolvimento poderá ser causa de responsabilização ao fornecedor, que obteve a sua autorização do Poder Público, principalmente se estamos em face de um medicamento, que busca melhorar a qualidade de vida do homem. ${ }^{73}$

\footnotetext{
72،“Art.194. As pessoas jurídicas de direito público interno são civilmente responsáveis pelos danos que os seus funcionários, nessa qualidade, causam a terceiros. Parágrafo único: Caber-lhes-á ação regressiva contra os funcionários causadores do dano, quando tiver havido culpa destes."

${ }^{73}$ João Calvão da Silva lembra a existência da Comissão para a Segurança de Serviços e Bens de Consumo e assevera: "A referida Comissão, sempre que as circunstâncias o aconselhem, dirigirá uma recomendação ao fabricante, importador ou fornecedor de bens ou prestador dos serviços que impliquem perigo para a saúde e segurança física dos consumidores, no sentido de suprimirem a sua perigosidade. Se a recomendação não for acatada ou as circunstâncias o exigirem, deve a Comissão emitir aviso adequado ao público, designadamente através dos órgãos de comunicação social, contendo uma descrição tão precisa quanto possível do bem ou serviço em causa, a identificação do risco especial que pode resultar da sua utilização e quaisquer outros elementos que considerem necessários.
} 


\author{
Realmente, a questão não é simples e requer estudo aprofundado sobre a \\ omissão do Estado perante eventual produto que o próprio Poder Público autorizou a \\ comercialização. ${ }^{74}$
}

Indaga-se se a viabilidade da repartição dos danos, de fato teve prévia análise por parte do Estado e não se pode eximir totalmente a responsabilidade do ente público, caso contrário, ocorreria um regresso à irresponsabilidade do Estado.

\footnotetext{
${ }^{74}$ De acordo com a Lei $n^{\text {o }}$ 6.360/1976 que dispõe sobre vigilância sanitária a que ficam sujeitos os medicamentos, as drogas, os insumos farmacêuticos e correlatos, cosméticos, saneantes e outros produtos, nos termos do artigo $6^{\circ}$ a comprovação de que determinado produto, até então considerado útil, é nocivo à saúde ou não preenche requisitos estabelecidos em lei implica na sua imediata retirada do comércio e na exigência da modificação da fórmula de sua composição e nos dizeres dos rótulos, das bulas e embalagens, sob pena de cancelamento do registro e da apreensão do produto, em todo o território nacional.

E no parágrafo único estabelece que é atribuição exclusiva do Ministério da Saúde o registro e a permissão do uso dos medicamentos, bem como a aprovação ou exigência de modificação de seus componentes.

$\mathrm{O}$ artigo $7^{\circ}$ dispõe que: "Como medida de segurança sanitária e à vista das razões fundamentadas do órgão competente, poderá o Ministério da Saúde, a qualquer momento, suspender a fabricação e venda de qualquer dos produtos de que trata esta Lei, que, embora, registrado, se torne suspeito de ter efeitos nocivos à saúde humana.

De fato cabe apenas à ANVISA cassar ou suspender o registro e a comercialização dos alimentos.

A validade do registro do produto está prevista pela Resolução no 23 de março de 2000: "7.1. Validade do registro: O registro dos produtos é válido por 05 (cinco) anos, em todo o território nacional. A revalidação do registro deve ser solicitada no prazo de até 60 (sessenta) dias, antes da data do seu vencimento." O Decreto-Lei 986/69 institui normas básicas quanto ao prazo que tem a Administração para a concessão do registro, nos termos do parágrafo $1^{\circ}$ do artigo $3^{\circ}$ : “art. $3^{\circ}$ Todo alimento somente será exposto ao consumo ou entregue à venda depois de registrado no órgão competente do Ministério da Saúde. $\S 1^{\circ} \mathrm{O}$ registro a que se refere este artigo será valido em todo território nacional e será concedido no prazo máximo de 60 (sessenta) dias a contar da data da entrega do respectivo requerimento, salvo os casos de inobservância dos dispositivos deste Decreto-Lei e de seus Regulamentos."

Tanto o registro quanto a revalidação são concedidos pela Anvisa, dessa forma, a responsabilização do Poder Público é indiscutível. Em muitos casos, a Anvisa, em razão de dificuldades operacionais, demora na análise de registro e revalidação dos produtos o que, sem dúvida, prejudica as empresas fornecedoras de produtos indispensáveis à saúde dos cidadãos.

O Decreto Federal n 79.094 de janeiro de 1977 dispõe sobre registro de medicamentos e outros produtos: “ Art. 14 Nenhum dos produtos submetidos ao regime de vigilância sanitária de que trata este Regulamento, poderá ser industrializado, exposto à venda ou entregue ao consumo, antes de registrado no órgão de vigilância sanitária competente do Ministério da Saúde.

$\S 1^{\circ} \mathrm{O}$ registro a que se refere este artigo terá validade por 5 (cinco) anos e poderá ser revalidado por períodos iguais e sucessivos, mantido o número de registro inicial.

$\S 6^{\circ}$ A revalidação do registro deverá ser requerida no primeiro semestre do último ano do quinquênio de validade, e no terceiro trimestre do biênio tratando-se de produtos dietéticos, considerando-se automaticamente revalidado o registro se não houver sido proferida decisão até a data do término do período respectivo."

Nos termos da legislação supra o requerimento de revalidação do produto é considerado automaticamente revalidado o registro, se não houver sido proferida decisão até a data do término do período respectivo, e até eventual decisão que indefira a revalidação, o que significa dizer que milita a presunção de que o produto obedece às normas de segurança para a saúde da população, pois, já foi testado e avaliado positivamente pelo órgão governamental competente.
} 


\subsubsection{Do direito à saúde}

$\mathrm{O}$ direito à saúde está insculpido no artigo $6^{\circ}$ da $\mathrm{CF}$ como direito social, bem como cabe ao Estado proporcionar a saúde de todos, mediante políticas sociais e econômicas que visem à redução do risco de doença e de outros agravos e ao acesso universal e igualitário às ações e serviços para sua promoção, proteção e recuperação, nos termos dos artigos 196 a 200 da Constituição Federal.

Jorge Tadeo Goffi Flaquer Scartezzini define o conceito de saúde pública como toda atividade que garanta de forma direta ou indireta a saúde da população, incluindo os meios pelos quais se instrumentaliza o bem-estar social. ${ }^{75}$

Nos termos do artigo 197 estabelece que cabe ao Poder Público dispor sobre sua regulamentação, fiscalização e controle, devendo sua execução ser feita diretamente ou por meio de terceiros e, também, por pessoa física ou jurídica de direito privado.

Vale lembrar que o artigo 199 prevê que a assistência à saúde é livre à iniciativa privada; o parágrafo $1^{\circ}$ estabelece que as instituições privadas poderão participar de forma complementar do sistema único de saúde, segundo diretrizes deste, mediante contrato de direito público ou convênio, tendo preferência as entidades filantrópicas e as sem fins lucrativos.

No artigo 200 o Estado delineia a forma de atuação no direito à saúde dos cidadãos, de forma a controlar e fiscalizar procedimentos, produtos e substâncias de interesse para a saúde e participar da produção de medicamentos, equipamentos, imunobiológicos, hemoderivados e outros insumos. Os incisos do supracitado artigo dispõem que o Poder Público deverá incrementar a área de atuação o de desenvolvimento científico e tecnológico, bem como deverá fiscalizar e inspecionar alimentos, compreendido o controle de seu teor nutricional, bem como bebidas e águas para consumo humano e participar do controle e fiscalização da produção, transporte, guarda e utilização de substâncias e produtos psicoativos, tóxicos e radioativos.

Por sua vez, a Lei 9.313/96 dispõe sobre a questão polêmica de distribuição gratuita de medicamentos, no caso dos portadores do HIV e doentes de AIDS:

\footnotetext{
${ }^{75}$ SCARTEZZINI, Jorge Tadeo Goffi Flaquer. Suspensão de segurança. São Paulo: Ed. Revista dos Tribunais, 2010. p. 96.
} 
"Art. $1^{\circ}$. Os portadores do HIV (vírus da imunodeficiência humana) e doentes de Aids (Síndrome da Imunodeficiência Adquirida) receberão, gratuitamente, do Sistema Único de Saúde, toda a medicação necessária ao tratamento.

$\$ 1^{\circ}$ O Poder Executivo, através do Ministério da Saúde, padronizará os medicamentos a serem utilizados em cada estágio evolutivo da infecção e da doença, com vistas a orientar a aquisição dos mesmos pelos gestores do Sistema Único de Saúde.

$\S 2^{\circ}$ A padronização de terapias deverá ser revista e republicada anualmente, ou sempre que se fizer necessário, para se adequar ao conhecimento atualizado e à disponibilidade de novos medicamentos no mercado. (grifos nossos)

Art. $2^{\circ}$ As despesas decorrentes da implantação desta lei, serão financiadas com recursos do orçamento da Seguridade Social da União, dos Estados, do Distrito Federal e dos Municípios, conforme regulamento."

Na lei supramencionada o Estado traz para si a responsabilidade da distribuição dos medicamentos para todos os portadores de HIV, sem aludir à qualquer distinção econômica entre os doentes. Prevê que o Ministério da Saúde deverá sempre trazer uma relação atualizada, ou sempre que novas descobertas científicas o recomendarem. Os recursos para a aquisição dos remédios serão oriundos dos orçamentos da seguridade social da União, dos Estados e dos Municípios. Não há como negar a efetiva presença do Estado na hipótese de algum medicamento vir a ser identificado como defeituoso após alguns anos da sua introdução no mercado. ${ }^{76}$

Recentemente, o STJ, por meio do Recurso Ordinário em Mandado de Segurança 28962/MG, de relatoria do Ministro Benedito Gonçalves, entendeu que o Estado deveria preconizar a saúde como direito social; todavia, tal obrigação deve ser analisada à luz do princípio da reserva do possível, ou seja, os pleitos deduzidos em face

\footnotetext{
${ }^{76}$ Marcos Maselli Gouvea observa que: "Circunstâncias as mais variadas, porém, fizeram com que o argumento da insuficiência do texto legal, outrora fatalmente admitido, não obtivesse mais a acolhida dos tribunais que, invertendo a tendência anterior, passaram a condenar o Estado não apenas à entrega de medicamentos, mas também à prestação dos serviços médicos necessários ao tratamento da síndrome. Impulsionadas por esta mudança no padrão decisório, ações versando o fornecimento de medicamentos para outras doenças foram se tornando cada vez mais frequentes e com maior porcentagem de êxito. $\mathrm{O}$ sucesso dos soropositivos impulsionou o reconhecimento do direito aos medicamentos por parte de outras classes de doentes, a despeito da inexistência de estatuto legal que amparasse esta extensão." (GOUVEA, Marcos Maselli. O direito ao fornecimento estatal de medicamentos. In: A efetividade dos direitos sociais. Rio de Janeiro: Lumen Juris, 2004. p. 203).
} 
do Estado devem ser logicamente razoáveis e, acima de tudo, é necessário que existam condições financeiras para o cumprimento dessa obrigação. ${ }^{77}$

Sem dúvida, pode-se exigir que o Estado articule alguma política de redução do risco da doença e de acesso universal e igualitário à promoção, proteção e recuperação de saúde, desde que não se converta em promessa constitucional inconsequente na definição do Min. Celso de Mello. ${ }^{78}$

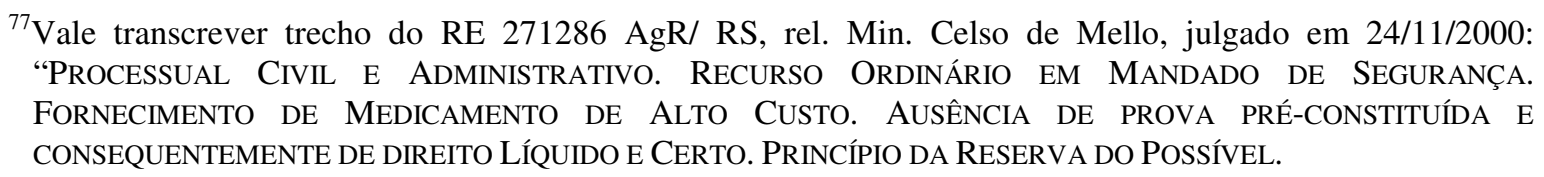
5. Apenas a título de argumento obter dictum, as ações ajuizadas contra os entes públicos com escopo de obrigar-lhes indiscriminadamente ao fornecimento de medicamento de alto custo devem ser analisadas com muita prudência.

6. O entendimento de que o Poder Público ostenta a condição de satisfazer todas as necessidades da coletividade ilimitadamente, seja na saúde ou em qualquer outro segmento, é utópico; pois o aparelhamento do Estado, ainda que satisfatório aos anseios da coletividade, não será capaz de suprir as infindáveis necessidades de todos os cidadãos.

7. Esse cenário, como já era de se esperar, gera inúmeros conflitos de interesse que vão parar no Poder Judiciário, a fim de que decida se, nesse ou naquele caso, o ente público deve ser compelido a satisfazer a pretensão do cidadão. E o Poder Judiciário, certo de que atua no cumprimento da lei, ao imiscuir-se na esfera de alçada da Administração Pública, cria problemas de toda ordem, como desequilíbrio de contas públicas, o comprometimento de serviços públicos, dentre outros.

8. $\mathrm{O}$ art. $6^{\circ}$ da Constituição Federal, que preconiza a saúde como direito social, deve ser analisado à luz do princípio da reserva do possível, ou seja, os pleitos deduzidos em face do Estado devem ser logicamente razoáveis e, acima de tudo, é necessário que existam condições financeiras para o cumprimento de obrigação. De nada adianta uma ordem judicial que não pode ser cumprida pela Administração por falta de recursos." (RMS 2896/MG, relatoria Min. Benedito Gonçalves, Primeira Turma, j. 25/08/2009)

${ }^{78}$ PACIENTE COM HIV/AIDS - PESSOA DESTITUÍDA DE RECURSOS FINANCEIROS - DIREITO À VIDA E À SAÚde FORNECIMENTO GRATUITO DE MEDICAMENTOS - DEVER CONSTITUCIONAL DO PODER PÚBliCO (CF, ARTS.5', CAPUT, E 196) - PRECEDENTES (STF) RECURSO DE AGRAVO IMPROVIDO. O DIREITO `A SAÚDE REPRESENTA CONSEQUENCIA CONSTITUCIONAL INDISSOCIÁVEL DO DIREITO À VIDA. - O direito público subjetivo à saúde representa prerrogativa jurídica indisponível assegurada à generalidade das pessoas pela própria Constituição da República (art.196). Traduz bem jurídico constitucionalmente tutelado, por cuja integridade deve velar, de maneira responsável, o Poder Público, a quem incumbe formular - e implementar - políticas sociais e econômicas idôneas que visem a garantir, aos cidadãos, inclusive àqueles portadores do vírus HIV, o acesso universal e igualitário à assistência farmacêutica e médico-hospitalar. - O direito à saúde além de qualificar-se como direito fundamental que assiste a todas as pessoas - representa consequencia constitucional indissociável do direito à vida. O Poder Público, qualquer que seja a esfera institucional de sua atuação no plano da organização federativa brasileira, não pode mostrar-se indiferente ao problema da saúde da população, sob pena de incidir, ainda que por censurável omissão, em grave comportamento inconstitucional. A interpretação da norma programática não pode transformá-la em promessa constitucional inconsequente - O caráter programático da regra inscrita no art.196 da Carta Política - que tem por destinatários todos os entes políticos que compõem, no plano institucional, a organização federativa do Estado brasileiro - não pode converter-se em promessa constitucional inconsequente, sob pena de o Poder Público, fraudando justas expectativas nele depositadas pela coletividade, substituir, de maneira ilegítima, o cumprimento de sua impostergável dever, por um gesto irresponsável de infelidade governamental ao que determina a própria Lei Fundamental do Estado. Distribuição Gratuita de Medicamentos a Pessoas Carentes - $\mathrm{O}$ reconhecimento judicial da validade jurídica de programas de distribuição gratuita de medicamentos a pessoas carentes, inclusive àquelas portadoras do vírus HIV/AIDS, dá efetividade a preceitos fundamentais da Constituição da República (arts. $5^{\circ}$, caput, e 196) e representa, na concreção do seu alcance, um gesto reverente e solidário de apreço à vida e à saúde das pessoas, especialmente daquelas que nada têm e nada possuem, a não ser a consciência de sua própria humanidade e de sua essencial dignidade. Precedentes do STF." 
No REsp $n^{\circ}$ 57.614-8/RS, julgado em 27/05/1996, que teve como Relator o Min. Demócrito Reinaldo, restou assentado que normas meramente programáticas protegem um interesse geral, mas não conferem aos respectivos beneficiários o poder de exigir a sua satisfação antes que o legislador cumpra o dever de complementá-las com a legislação integrativa.

No artigo $2^{\circ}$ da Lei $n^{\circ} 8080 / 90$ que dispõe sobre a promoção, proteção e recuperação da saúde, a organização e o funcionamento dos serviços correspondentes, se reconhece o direito à saúde como direito fundamental do ser humano, devendo o Estado prover as condições indispensáveis ao seu pleno exercício.

A polêmica é no fato de que as prestações estatais demandam um dispêndio ostensivo de recursos públicos, os quais, são finitos e, por outro lado, os interesses que poderão ser erigidos à condição de direitos exigíveis. A esse contingenciamento financeiro a doutrina denomina de reserva do possível jurídica.

Para Ronald Dworkin acusa para o irrealismo da obrigação do Estado ser responsabilizado por todas as demandas na área da saúde. ${ }^{79}$

\subsection{Da livre iniciativa e proteção do consumidor}

A ordem econômica fundada na valorização do trabalho humano e da livre iniciativa tem por objetivo a defesa do consumidor, inciso $\mathrm{V}$ do artigo 170 da $\mathrm{CF} / 88$, nos seguintes termos: "a ordem econômica, fundada na valorização do trabalho e na livre iniciativa, tem por fim assegurar a todos existência digna, conforme os ditames da justiça social, observados os seguintes princípios."

Percebe-se a preocupação do constituinte ao valorizar o trabalho e a livre iniciativa, que iniciam o processo de humanização, tendo por fim assegurar a todos existência digna, conforme os ditames de justiça social, sendo, indiscutivelmente, a livre iniciativa o ponto fundamental da ordem econômica pátria.

\footnotetext{
${ }^{79}$ Sovereign Virtue, Cambridge (Mass): Oxford, 2000, p. 309 e ss. apud GOUVEA, Marcos Maselli. op. cit., p. 219.
} 
É inquestionável a possibilidade de exploração do mercado, mesmo porque todos estão interessados na atividade desenvolvida pelo empresário, e, obviamente, certos limites devem ser respeitados. Sem dúvida, a lei garante existência digna. ${ }^{80}$

A livre iniciativa é também consagrada no inciso IV do artigo $1^{\circ}$ da Constituição como fundamento da República. É a liberdade individual no plano da produção, circulação e distribuição das riquezas, o que significa dizer que há a livre escolha e o livre acesso às atividades econômicas.

A questão é como harmonizar a livre iniciativa com a proteção do consumidor. Eros Grau ressalta que a livre iniciativa é um conceito extremamente amplo, que não se limita à liberdade de iniciativa econômica. ${ }^{81} 82$

Fábio Comparato afirma que, na hipótese de conflito entre o princípio da livre iniciativa e o da proteção ao consumidor, deverá prevalecer o último.

O artigo 170 da CF impõe ao Estado o dever de intervir nas relações existentes entre consumidores e fornecedores, em contraponto às ideias neoliberais de livre comércio, que sempre foram contrárias a qualquer forma de ingerência estatal. ${ }^{83}$

\footnotetext{
${ }^{80}$ Márcio Mello Casado observa: "Certamente, quando o caput do art. 170 determina que a ordem econômica tem por fim assegurar, a todos, existência digna, está estabelecendo uma diretriz fundamental, um objetivo elementar do Estado nacional. Já os incisos do art.170 são os imperativos de justiça da República Brasileira, no que concerne à ordem econômica.

Para alcançar o objetivo de construção de uma existência digna aos destinatários das normas constitucionais, o constituinte entendeu como um dos imperativos de justiça, o que interessa neste momento, a este estudo, a defesa do consumidor.

A lei deve defender, agir em favor do consumidor. Let the poor pay less, nas palavras de Thomas Wilhemsson, pois, segundo, a nossa visão, o vulnerável precisa ser menos onerado (seria algo como the poor needs to pay less).

Mais uma vez se observa o ideal de estabelecimento de uma igualdade real, agora vista como imperativo de justiça no país." (CASADO, Márcio Mello. Proteção do consumidor de crédito bancário e financeiro. 2. ed. São Paulo: Ed. Revista dos Tribunais, 2006. p. 32-33).

${ }^{81}$ GRAU, Eros. A Ordem Econômica na Constituição de 1988 (interpretação e crítica). 2. ed. São Paulo: Ed. Revista dos Tribunais, 1991. p. 221.

${ }^{82} \mathrm{O}$ Autor ressalta que: "Será possível afirmar que a proteção ao consumidor deve subordinar-se ao princípio da liberdade empresarial ? Não é, pelo contrário, o inverso que deve ser sustentado, como advertiu lucidamente Adam Smith ? Faz sentido defender-se, ainda hoje, que a livre concorrência é garantida pelo Estado em benefício dos próprios concorrentes e não do mercado como um todo e do consumidor em especial, como razão de ser e objetivo dessa liberdade empresarial ? Contra o que deve o consumidor ser protegido, senão contra os interesses próprios dos produtores e distribuidores de bens, ou prestadores de serviços? De que maneira se pode dar algum sentido concreto e coerente a mandamento constitucional de defesa do consumidor, se este há de se submeter ao interesse dos empresários?" (RDM nº 80, P. .66 a 75).

${ }^{83}$ Renato Moreira Dorneles observa: “Dessa forma, conforme pudemos observar ao longo deste artigo, a intervenção do Estado brasileiro nas relações de consumo é obrigatória e de suma importância para o desenvolvimento de nosso País. Contudo não se pense que a realização da intervenção estatal nas relações de consumo deve ser feita de acordo com o cunho ideológico dos governantes. Muito pelo contrário, este é um tema objetivo, e deve ser tratado de forma técnica (cientifica), séria e responsável. A intervenção estatal, nesse sentido, deve ser capaz de trazer resultados efetivos à população que almeja melhor
} 
Sem dúvida, o princípio da ordem econômica da Constituição Federal é limitador da autonomia da vontade dos fortes em relação aos vulneráveis. Foi reconhecido o papel do consumidor na sociedade e, consequentemente, a necessidade de sua proteção no mercado, sendo, indiscutivelmente, elementos inerentes ao direito privado.

Nessa seara, o princípio da autonomia da vontade particulariza-se na liberdade de contratar e esse, por sua vez, do princípio da livre iniciativa, sendo a máxima pacta sunt servanda um dos pilares da economia de mercado, sem, contudo, ser possível interpretar que a liberdade de contratar seja irrestrita.

De fato, o princípio da livre iniciativa identificado com a "liberdade econômica" ou "liberdade de iniciativa econômica", cujo titular é a empresa, implica a liberdade de desenvolver a atividade, a liberdade de concorrência e a liberdade de contratar.

Orlando Gomes adverte que a política interventista do Estado atingiu, por sua vez, o contrato, na sua cidadela, ao restringir a liberdade de contratar, na sua tríplice expressão da liberdade de celebrar contrato, da liberdade de escolher o outro contratante e da liberdade de determinar o conteúdo do contrato. ${ }^{84}$

\subsubsection{Do conflito entre empresa e consumidor}

A grande protagonista da atividade econômica é, sem dúvida, a grande empresa que influencia de modo significativo no setor econômico. Sob esse aspecto, há que se considerar o potencial conflito entre empresa e consumidor.

Contudo, sendo o consumidor o maior interessado e o destinatário da produção, o consumo é um simples momento, por isso nunca poderia ocorrer um conflito entre empresa e consumidores, mesmo porque, ao contrário da relação capital x trabalho, a relação

atendimento e responsabilização dos maus fornecedores na prestação de serviços e na venda de produtos no mercado brasileiro. (...)

Por fim, a defesa do consumidor, prestada que deve ser pelo Estado, é garantia prevista no mais alto patamar normativo de nossa Carta Magna. Trata-se de direito fundamental de todo cidadão, cujo Código de Defesa do Consumidor, como norma exemplar que é em diversos países, infelizmente, ainda hoje, passados doze anos de sua entrada em vigor, continua sendo sustentado, com dificuldades, somente pelo longo braço da tutela jurisdicional." (DORNELES, Renato Moreira. A intervenção estatal brasileira nas relações de consumo: estrutura legislativa e fundamentos. RDC nº 54, São Paulo, abr/jun, 2004, P. 70).

${ }^{84}$ GOMES, Orlando. Contratos. 11. ed. Rio de Janeiro: Forense, 1986. p. 9. 
produtor x consumidor não comporta definições claras e separações radicais. A rigor, todos nós somos consumidores, até mesmo o Estado. ${ }^{8586}$

Além disso, o próprio consumidor é visto como um homem econômico pela empresa por meio de suas escolhas, que constituem o elemento essencial e dominante da teoria econômica. Com efeito, os comportamentos individuais das pessoas influenciam as empresas. $^{87}$

A busca incessante pela satisfação faz com que haja ao mesmo tempo uma crescente frustração delineando o fenômeno do consumismo, com o uso desenfreado de bens e serviços para que cada vez mais haja o acúmulo de dinheiro e riqueza. O impulso ao

${ }^{85}$ Newton De Lucca pondera: "Eis porque, na arbitragem de conflitos desse tipo, nem sempre nos deparamos com uma nítida distinção entre 'fracos' e 'poderosos', em campos opostos. Os consumidores mais desprotegidos, diante de uma medida administrativa que afete o interesse do organismo de produção para o qual trabalham, tenderão a tomar o partido deste e não da 'classe' dos consumidores em geral, como se tem visto, em episódios recentes. Por outro lado, o Estado, o consumidor ele próprio, mas também intimamente ligado aos interesses dos produtores, costuma pender para o lado destes, salvo quando sacudido por violentas campanhas de opinião pública.” (DE LUCCA, Newton. op. cit., p. 46).

${ }^{86}$ Rodrigo Bernardes Dias adverte: "Muito pouco explorada pela doutrina tem sido a possibilidade de pessoas jurídicas de direito público serem consideradas consumidoras. Sem dúvida o assunto não foi suficientemente abordado em nossa doutrina e, entre os poucos que o mencionaram não há unanimidade.

Entretanto, em que pese o respeito às posições divergentes, particularmente concordamos com uma concepção maximalista do CDC e, consequentemente, defendemos a ideia de que as pessoas jurídicas de direito público, tanto da administração pública direta como indireta, estão incluídas no conceito de consumidor com base em diversos motivos que serão considerados a seguir." (DIAS, Rodrigo Bernardes. Debates em direito público: A aplicação do Código do Consumidor aos contratos celebrados com pessoas jurídicas de direito público interno.)

${ }^{87}$ Roger Bowles esclarece: “ L'elemento cardine sul quale si basa gran parte dell'analisi economica è il comportamento dei singoli soggetti economici. Le scelte operate dalle imprese o dai governanti, ad esempio, possono essere ricostruite mediante l'analisi del comportamento dei consumatori, degli azionisti o degli elettori. É proprio l'assunzione delle ipotesi circa i comportamento individuali, che costituisce l'elemento essenziale e dominante della teoria economica. Se non si tiene nella dovuta considerazione il modo con cui i soggetti reagiscono di fronte ai vincoli o alle oportunità che si presentano loro, vi è ben poca speranza di riuscire a comprendere o a prevere l'evoluzione di una qualsiasi parte dell'economia è divenuto pertanto proprio quello di ricercare i modelli piú apropriati di comportamento dei soggetti economici. Il risultato è stato l'idealizione di un homo oeconomicus, ovvero di un soggetto che si comporta sempre con un certo grado di coerenza logica. É sicuramente piuttosto facile trovare qualcuno capace di obiettare come l'ipotesi secondo cui gli esseri umani sono creature perfettamente razionali, egoiste e in grado di manipolare cinicamente l'ambiente in cui vivono al solo scopo di massimizzare il proprio tornaconto personale, possa aparire alquanto semplicista. È sicuramente più difficile trovare invece chi sia in grado de proporre altre valide alternative. Lo scopo principale dei primi paragrafi di questo capitolo è proprio quello di fornire qualche idea circa il modo con cui gli economisti sono giunti a riternere molto utile indagare sul comportamento dei singoli soggetti economici. Dopo aver tracciato un quadro sul comportamento individuale sarà poi possibile scendere maggiormente nei dettagli confrontando tale quadro sul comportamento individuale verrà costruito in un primo momento in un contesto di neutralità istituzionale e, successivamente, inserito in un modo in cui esistono i beni, i servizi, gli organismi pubblici e privati e, tra le altre cose (peraltro forse la piú importante ai nostri scopi), un sistema giuridico."( BOWLES, Roger. op. cit., p. 52-53).

Roger Bowles destaca que as escolhas feitas pelas empresas ou pelos governantes podem se basear no comportamento dos consumidores, dos acionistas o dos eleitores. Procura-se também identificar um sujeito que atua segundo critérios de carência lógica, para depois traçar um comportamento geral, abstraindo-se as diferenças individuais. A ideia é construir uma neutralidade institucional, na qual se inserem os bens, os serviços e os próprios entes públicos. 
consumo é sustentado pelo objetivo de quanto mais se produz, mais se pode ter e, consequentemente, uma forma de manter o próprio prestígio.

Em uma sociedade de consumo em que o próprio corpo pode ser objeto de consumo, questiona-se qual é a urgência de defender o homem do consumo.

Guido Alpa observa que a contraposição de interesses é lugar comum em muitas análises e isso pode ser facilmente resolvido, mas apenas depois que for definida a questão da admissão de uma categoria homogênea de consumidor. Afirma que o consumidor não pode constituir uma categoria uniforme e homogênea, mesmo porque os consumidores não são portadores de interesses entre eles homogêneos, como são os interesses da categoria, sendo ricos e pobres, instruídos e ignorantes.

Pondera o Autor supracitado que o mais razoável é propor a eliminação dos efeitos nocivos, salvando quanto de positivo existe na sociedade, com uma produção racional e apurada seleção das necessidades e do consumo, eliminando os defeitos. ${ }^{88}$

Alpa critica aqueles que sustentam se resumir a lógica social do consumo ao capitalismo avançado, que induz a acreditar na observância de modelos uniformes de comportamento, no uso idêntico de produtos, na busca pelas mesmas satisfações, levando os indivíduos ao mesmo nível de gostos e de escolhas. O ponto de equilíbrio seria, sem dúvida, a ética do mercado. Atualmente, não se concebe mais o mercado como fim, mas, sim, como instrumento.

Há que se repensar a relação entre direito e economia, sem se esquecer que a dignidade humana está posicionada no ápice da hierarquia dos valores previstos pela Constituição. Efetivamente, empresa e consumidor ou mercado e pessoa são dois termos frequentemente contrapostos, mas que uma visão unitária e sistemática do ordenamento contribui a evidenciar o seu significado positivo e o seu recíproco condicionamento. ${ }^{89}$

Maria Cristina de Cicco lembra que a União Europeia caminha paulatinamente para uma proteção do consumidor como pessoa e não mais exclusivamente como sujeito de uma relação econômica. Ainda não ocorreu o reconhecimento da pessoa como valor absoluto do ordenamento, dando, como exemplo, a Diretiva ${ }^{\circ} 95$ de 2001 sobre segurança geral dos produtos que, de um lado, tende a reforçar a obrigação geral de segurança e a

\footnotetext{
${ }^{88}$ BOWLES, Roger. op. cit., p. 16.

${ }^{89}$ DE CICCO, Maria Cristina. A pessoa e o mercado. In: TEPEDINO, Gustavo (Org.). Direito civil contemporâneo: novos problemas à luz da legalidade constitucional. Anais do Congresso Internacional de Direito Civil-Constitucional da Cidade do Rio de Janeiro. Atlas, 2008. p. 103-104.
} 
melhorar as disposições sobre segurança dos produtos, compatível com um nível elevado de proteção da segurança e da saúde das pessoas na União Europeia, e de outro, tem como objetivo a garantia de um adequado funcionamento do mercado interno. ${ }^{90}$

${ }^{90}$ DE CICCO, Maria Cristina. op. cit., p. 106. 


\title{
CAPÍTULO III. DO CÓDIGO DE DEFESA DO CONSUMIDOR
}

\author{
SuMÁRIO: 3. A RELAÇÃO DE CONSUMO - 3.1. CONCEITO DE \\ CONSUMIDOR - 3.1.1 DO PAPEL DO CONSUMIDOR. - 3.2. DO CONCEITO DE \\ FORNECEDOR. - 3.3. DO DEVER DE INFORMAÇÃO.
}

\section{A relação de consumo}

A compreensão do direito do consumidor pressupõe uma consciência de economia de mercado. Assim, para alguns, o protagonismo não cabe ao consumidor, mas ao mercado ${ }^{91}$. Na verdade, o objeto de regulamentação do CDC é a relação de consumo, termo mais abrangente do que ato de consumo ou ainda contrato de consumo. ${ }^{92}$

O Brasil foi pioneiro na elaboração de Código para a Defesa do Consumidor, já na década de 90. A Assembleia Nacional Constituinte positivou na Constituição de 1988 o programa constitucional, que inseria no ordenamento jurídico o CDC. Essa situação

\footnotetext{
${ }^{91}$ Paula Forgioni observa: “A exposição até aqui empreendida deságua em uma das principais questões hoje enfrentada pelos teóricos do direito comercial: a compreensão do mercado. A desorientação pode ser comparada àquela reportada por Asquini sobre a doutrina produzida após os primeiros contatos com o então novo Codice Civile. Deve-se aqui parafraseá-lo para alertar: é tempo de reconhecer que a matéria mais viva e mais rica de conteúdo na teoria jurídica do direito comercial é hoje dada pelo mercado e, assim, a construção dessa teoria é, sobretudo, um dever - "o nosso dever" - da ciência do direito comercial.

Mercado é palavra polissêmica "em que, ao mesmo tempo, tudo cabe e nada se contém". Empregada para referir desde o local onde a dona-de-casa faz suas compras semanalmente até a forma ótima de alocação de recursos em determinada sociedade, assume diante dos nossos olhos o papel de solução para todos os males (“deixemos por conta do mercado!") e de grande responsável pelas mazelas humanas ("é culpa do mercado!").

Referimo-nos ao mercado como sujeito. Apresenta-se anônimo e independente da "vontade" de alguém, mas assume marcante personalidade, a ponto de ser referido não apenas como pessoa, mas, às vezes, como deus, cuja vontade é impossível contrariar. Alguns o vêem no preâmbulo de nossa Constituição, outros restam embevecidos com "mágica do mercado". Ele acorda "nervoso" ou "tranquilo", "reage bem" à declaração do presidente, "comemora" a eleição de "seu" candidato (o mercado tem seus candidatos!). Existe entre nós como um "grande irmão", que tudo sabe e a tudo reage. Moinho satânico, tritura nossos valores e afeições."' (FORGIONI, Paula. A evolução do direito comercial brasileiro: da mercancia ao mercado. São Paulo: Ed. Revista dos Tribunais, 2009. p 188-189).

${ }^{92}$ Nelson Nery Junior asseverou: "de regulamentação pelo Código de Defesa do Consumidor é a relação de consumo, assim entendida a relação jurídica existente entre fornecedor e consumidor tendo como objeto a aquisição de produtos ou utilização de serviços pelo consumidor...O CDC não fala de 'contrato de consumo', 'ato de consumo', 'negócio jurídico de consumo', mas de relação de consumo, termo que tem sentido mais amplo do que aquelas expressões. São elementos da relação de consumo, segundo o CDC: a) como sujeitos, o fornecedor e o consumidor; b) como objeto, os produtos e serviços; c) como finalidade, caracterizando-se como elemento teleológico das relações de consumo, serem elas celebradas para que o consumidor adquira produto ou se utilize de serviço 'como destinatário final' (art. $2^{\circ}$, caput, última parte, CDC)” (In: GRINOVER, Ada Pelegrini et. al. Código Brasileiro de Defesa do Consumidor cit., p. 342).
} 
diverge, por exemplo, da legislação francesa, cujo regramento decorreu de simples decisão ministerial.

Paula Forgioni assevera que há muito tempo existem entre nós normas de proteção à economia popular, esboçando, de certa forma, tutela consumerista, mas, paulatinamente, foi-se admitindo a necessidade de disciplina especial para esse aspecto, aumentando o grau de confiança dos consumidores em prol do tráfico mercantil. Afirma ainda que os contratos estabelecidos entre empresas e consumidores passaram a se sujeitar ao sistema consumerista, regidos por princípios peculiares, diversos daqueles do direito mercantil. $^{93}$

O CDC ensejou o surgimento de movimento conhecido como consumerismo, a fim de se afastar do pensamento liberal e patrimonialista do direito privado.

O Código de Defesa do Consumidor assegura o princípio da boa-fé objetiva, da função social da propriedade, do equilíbrio econômico dos contratos, e da responsabilidade objetiva advinda do risco.

Com efeito, todos os países possuem leis que, em menor ou maior grau, regulam o mercado e protegem os consumidores.

Logo em seguida à criação do CDC brasileiro, em 1993, é aprovado o Code la Consommation na França. Já na Itália, um pouco mais tarde é aprovado o Codice del Consumo. A Holanda, por outro lado, prefere a integração da matéria no Código Civil. Entretanto, na Europa existe a produção comunitária de normas, através das Diretivas.

Questiona-se se a localização do direito do consumidor, na medida em que estuda a relação de consumo, entre os ramos do direito poderia ser ramo autônomo ou poderia integrar-se a algum dos ramos de direito. ${ }^{94}$ Sem dúvida, o direito do consumidor deve ser

\footnotetext{
${ }^{93}$ FORGIONI, Paula. op. cit., p 133-134.

${ }^{94}$ José de Oliveira Ascensão elucida a questão : "Qual ? Poderia pensar-se que seria no Direito da Economia. Encontramos sempre uma atividade econômica e, mais ainda, um fornecedor que age profissionalmente. A suspeita avoluma-se quando se nota que muitas vezes se fala em Direito do Consumo e não em Direito do Consumidor: aliás, o recente código italiano chama-se justamente Codice del Consumo. Ora o consumo é uma função econômica e a disciplina das funções econômicas pareceria caber a um vasto e ainda pouco definido Direito da Economia.

Mesmo centrado este ramo no consumidor, poderia reconduzir-se a uma categoria que por alguns tem sido aventada, um vastíssimo Direito dos Comportamentos no Mercado. Regularia as várias condutas que se praticam no mercado e a conduta do consumidor integra-se seguramente nele. Mas é muito duvidoso que se justifique um ramo do Direito tão amplo que seria praticamente impossível traçar-lhe fronteiras, por ir da defesa da concorrência à regulação profissional. Assim perder-se-ia de vista o que é constitutivo do Direito do Consumidor: a própria defesa do consumidor. É esse núcleo que carece por si de ser situado." (ASCENSÃO, José de Oliveira. Revista Trimestral de Direito Civil, Rio de Janeiro, v. 32, p. 182, out./dez. 2007).
} 
compreendido como uma área do saber jurídico acerca da disciplina da ordem econômica e não apenas uma introdução de boas condutas no mercado.

Indiscutivelmente, há ligação com o direito econômico, pois sempre existe uma atividade econômica, a qual pressupõe, impreterivelmente, fornecedor na relação jurídica. Em razão disso, o próprio ordenamento jurídico italiano o denominou de código do consumo.

A importância do CDC para a sociedade atual é indiscutível; na medida em que o consumo é uma forma de relação social, percebe-se uma identidade entre o mundo do consumo e o mundo vital. ${ }^{95}$

\subsection{Conceito de consumidor}

O consumidor é toda e qualquer pessoa com condições de adquirir um serviço ou um produto. A defesa do consumidor, diante da vastíssima extensão, requer formulação tal que deve estar caracterizada pela situação de vulnerabilidade.

Sob o ponto de vista econômico, o consumidor, ao adquirir um produto, constitui o ato pelo qual se completa a última etapa do processo econômico. Para Newton de Lucca o CDC teria adotado, de certo modo, um conceito de caráter econômico. De fato, todas as vezes que se recorre aos fornecedores de bens ou serviços, desempenhando papel de agente econômico, desempenha-se a condição de consumidores em sentido econômico. ${ }^{96}$

José Geraldo Brito Filomeno define consumidor, no aspecto sociológico, da seguinte forma:

"Já do ponto de vista sociológico é considerado consumidor qualquer indivíduo que frui ou se utiliza de bens e serviços, mas pertencente a uma determinada categoria ou classe social. Eis aí o elo de ligação entre

\footnotetext{
${ }^{95}$ Silney Alves Tadeu observa: “A proposta deste ensaio, em consonância com Morace, é alentar que o consumo é uma forma de relação social, intrinsecamente vinculada com os modos de produção e reprodução social da modernindade avançada. $\mathrm{O}$ consumo se estenderia muito além dos objetivos materiais e os consumos culturais, para abranger outros âmbitos, como a religião, a política ou mesmo inclusive a própria vida laboral, por sua natureza produtiva, e que estaria mais próxima da obtenção de recursos que de seu gasto, pois como assinala Bauman (1999), o trabalho converteu-se em um bem estético, no qual gastamos boa parte de nosso dia e cuja possibilidade de eleição é sem dúvida equiparável a possibilidade de acesso a outros bens de consumo, como a moradia. Desde logo, a onipresença do consumo alcança a investigação genética e o futuro da manipulação de seres humanos através de seus potenciais clientes ou consumidores." (TADEU, Silney Alves. As dimensões do consumo: reflexões para uma teoria compreensiva. Revista de Direito do Consumidor, São Paulo, n. 56, p. 203, out./dez. 2005).

${ }^{96}$ DE LUCCA, Newton. op. cit., p. 113-114.
} 
o chamado 'movimento trabalhista ou obreiro' ou ainda 'sindicalista' e o 'movimento consumerista', vez que, por razões evidentes, a noção de melhor qualidade de vida pressupõe certamente o próprio poder aquisitivo para dar vazão ao desejo de consumir produtos e contratar serviços em maior escala e igualmente de melhor qualidade." 97

Sem dúvida, a sociologia contribui para observação realista da sociedade, em razão dos diferentes graus de rendimento e de capacidade reinvidicativa.

Carlos Ferreira de Almeida destaca a importância da análise sociológica. O consumerista português faz o seguinte comentário:

"A análise sociológica é certamente fecunda para que as leis e os seus agentes de aplicação suspeitem do igualitarismo conceitual; é, sem dúvida, um importante contributo para a relacionação interdisciplinar das noções de cidadão, de trabalhador e de consumidor. Mas não contém suficiente nitidez dum ponto de vista normativo, para que resultem recortados os direitos e as obrigações individuais que precedem os actos de consumo ou destes derivem." 98

Claudia Lima Marques salienta que em todas as Diretivas europeias a definição de consumidor seria a de pessoa física que age fora de sua profissão, para fins privados, diante de um profissional. ${ }^{99}$

Afirma, ainda, que a proteção conferida ao consumidor deve ter amplitude internacional, o próprio direito do consumidor teria "vocação internacional". Os direitos econômicos e sociais estariam resguardados em todos os mercados.

O caput do artigo 2 assim prevê: "Consumidor é toda pessoa física ou jurídica que adquire ou utiliza produto ou serviço como destinatário final." Há duas interpretações para a expressão destinatário final, ou seja, duas correntes, a maximalista e a finalista. ${ }^{100}$

\footnotetext{
${ }^{97}$ FILOMENO, José Geraldo Brito. Manual de direitos do consumidor. São Paulo: Atlas, 2007. p. 24-25.

${ }^{98}$ ALMEIDA, Carlos Ferreira de. Os direitos dos consumidores. Coimbra: Almedina, 1982.

${ }^{99}$ MARQUES, Claudia Lima. Contratos no Código de Defesa do Consumidor: o novo regime das relações contratuais, cit.

${ }^{100}$ A legislação argentina recentemente propôs a nova redação do artigo $1^{\circ}$ da Lei 24.240 , o texto atual dispõe que: "a toda persona física o juridica que adquiere o utiliza bienes o servicios en forma gratuita ou onerosa, como destinatario final, en beneficio proprio o de su grupo familiar o social" Em tradução livre o texto prevê que toda pessoa física ou jurídica que adquire ou utiliza bens ou serviços de forma gratuita ou onerosa, como destinatário final, em benefício próprio ou de seu grupo familiar ou social. O conceito de consumidor harmoniza-se com os demais países do Mercosul, pois o critério inclui no conceito de consumidor toda pessoa física ou jurídica. Outrossim, há o aspecto econômico de consumo, ou seja, o sujeito deve atuar no mercado como destinatário final dos bens e serviços. Isso significa dizer que o produto ou serviço é retirado do mercado, não retornando sem incorporação a um novo processo de
} 
Para os maximalistas, o destinatário final seria toda pessoa que adquire um produto ou serviço (destinatário fático); a interpretação dada é que a empresa que compra bens para utilizá-los como insumo na sua produção também seria consumidora.

Por outro lado, os finalistas acreditam que o destinatário final é aquele que adquire um bem para utilizar como destinatário fático e econômico; isso significa dizer que o destinatário final deve utilizar para consumo próprio. ${ }^{101}$

elaboração de bens ou de prestação de serviços. O bem ou serviço deve ser empregado para uso privado, familiar ou social.

Para Carlos A. Hernández e Sandra A. Frustagli o sentido da reforma foi admitir a essa categoria de pessoas jurídicas dentro da proteção legal, quando atuem fora do âmbito de sua atividade profissional, dá uma margem de proteção às pequenas e médias empresas quando atuem fora do âmbito de experiência profissional, uma vez que podem apresentar a mesma vulnerabilidade que a pessoa física.

Concluem que com essa orientação a nova lei confirma a tendência jurisprudencial validada também para um setor de nossa doutrina que postula uma interpretação menos rigorosa.

(HERNANDEZ, Carlos A; FRUSTAGLI, Sandra A. Primeras consideraciones sobre los alcances de la reforma a la Ley de Defensa del Consumidor, con especial referencia a la materia contractual. Revista de Direito do Consumidor, São Paulo, v. 17, n. 67, p. 247, jul./set. 2008).

${ }^{101}$ Vale transcrever os seguintes julgados: "Direito do consumidor. Recurso especial. Conceito de consumidor. Critério subjetivo ou finalista. Mitigação. Pessoa jurídica. Excepcionalidade. Vulnerabilidade. Constatação na hipótese dos autos. Prática abusiva. Oferta inadequada. Característica, quantidade e composição do produto. Equiparação (art. 29). Decadência. Inexistência. Relação jurídica sob a premissa de tratos sucessivos. Renovação do compromisso. Vício oculto. A relação jurídica qualificada por ser 'de consumo' não se caracteriza pela presença de pessoa física ou jurídica em seus polos, mas pela presença de uma parte vulnerável de um lado (consumidor), e de um fornecedor, de outro. Mesmo nas relações entre pessoas jurídicas, se da análise da hipótese concreta decorrer inegável vulnerabilidade entre a pessoa jurídica consumidora e a fornecedora, deve-se aplicar o CDC na busca do equilíbrio entre as partes. Ao consagrar o critério finalista para interpretação do conceito do consumidor, a jurisprudência deste STJ também reconhece a necessidade de, em situações específicas, abrandar o rigor do critério subjetivo do conceito do consumidor, para admitir a aplicabilidade do CDC, nas relações entre fornecedores e consumidores-empresários em que fique evidenciada a relação de consumo. São equiparáveis a consumidor todas as pessoas, determináveis ou não, expostas às práticas comerciais abusivas. Não se conhece de matéria levantada em sede de embargos de declaração, fora dos limites da lide (inovação recursal). Recurso especial não conhecido." (STJ, 3 ${ }^{\mathrm{a}}$ T., REsp 476.428/SC, rel. Min. Nancy Andrigui, j.19.04.2005, DJ 09.05.2005).

Em outra decisão, o Min. Jorge Scartezzini proferiu o voto no sentido de dar certo abrandamento na interpretação finalista: "3. No tocante ao segundo aspecto - inexistência de relação de consumo e conseqüente incompetência da Vara Especializada em Direito do Consumidor - razão assiste ao recorrente. Ressalto, inicialmente, que se colhe dos autos que a empresa - recorrida, pessoa jurídica com fins lucrativos, caracteriza-se como consumidora intermediária, porquanto se utiliza do serviço de fornecimento de energia elétrica prestado pela recorrente, com intuito único de viabilizar sua própria atividade produtiva. Todavia, cumpre consignar a existência de certo abrandamento na interpretação finalista, na medida em que se admite excepcionalmente, desde que demonstrada, in concreto, a vulnerabilidade técnica, jurídica ou econômica, aplicação das normas do CDC.

Quer dizer, não se deixa de perquirir acerca do uso profissional ou não do bem ou serviço; apenas, como execução e à vista da hipossuficiência concreta de determinado adquirente ou utente, não obstante seja um profissional, passa-se a considerá-lo consumidor.

Ora, in casu, a questão da hipossuficiência da empresa recorrida em momento algum foi considerada pelas instâncias ordinárias não sendo lídimo cogitar a respeito dessa seara recursal, sob pena de indevida supressão de instância. (Precedentes: REsp 541.867/BA, DJ 10.11.2004)

Por tais fundamentos, CONHEÇO PARCIALMENTE DO RECURSO ESPECIAL, E, NESTA PARTE, DOU-LHE PROVIMENTO, para, afastando a relação de consumo, determinar a incompetência absoluta do juízo de Direito da $1^{a}$ Vara Especializada da defesa do consumidor para processar e julgar o feito. 
A vulnerabilidade é fator importante para o conceito de destinatário final, pois quem adquire um bem para consumo e está em posição de desvantagem perante o fornecedor será consumidor, sendo irrelevante a destinação que se dê ao produto. Esse conceito inclui pequenos empresários que adquirem os produtos para incrementar suas produções. Para Claudia Lima Marques, seria uma destinação final aprofundada. ${ }^{102}$

No caso do consumidor não profissional, a situação de vulnerabilidade é presumida, bem como para o consumidor pessoa física, o que não acontece com os profissionais e às pessoas jurídicas, pois vale a presunção em contrário - para estes exigese o mínimo de conhecimentos jurídicos. Não é a mera desigualdade de condições financeiras suficientes para configurar a vulnerabilidade que caracteriza a relação de consumo. $^{103}$

O fator determinante para a extensão do conceito de consumidor é, sem dúvida, a vulnerabilidade de acidente de consumo, independentemente se é terceiro ou intermediário na relação de consumo.

Outrossim, há que se vislumbrar que, além do conceito padrão previsto no artigo $2^{\circ}$, o artigo 17 prevê consumidores por equiparação; dessa forma, equiparam-se aos consumidores todas as vítimas do evento. Por força desse dispositivo não se exige destinação final, apenas os pressupostos da responsabilidade: o dano, o nexo de causalidade e o defeito.

Frise-se que para entender o âmbito de aplicação da norma em análise é preciso fazer a seguinte distinção entre responsabilidade por fato e por vício do produto e do serviço.

Reconheço, outrossim, a nulidade dos atos processuais praticados e determino a distribuição do processo a um dos Juízos Cíveis da Comarca deVitória/ES” (STJ, REsp 661.145/ES, rel. Min. Jorge Scartezzini, j. 22/02/2005, DJ 28/03/2005).

102،Civil. Relação de consumo. Destinatário final. A expressão destinatário final, de que trata o art. $2^{\circ}$, caput, do CDC abrange quem adquire mercadorias para fins não econômicos, e também aqueles que, destinandose a fins econômicos, enfrentando o mercado de consumo em condições de vulnerabilidade; espécie em que caminhoneiro reclama a proteção do CDC porque o veículo adquirido utilizado para prestar serviços que lhe possibilitariam sua mantença e a da família, apresentou defeitos de fabricação. Recurso especial não conhecido." (STJ, 3 $3^{\mathrm{a}}$ T., REsp 716.877/SP, rel. Min. Ari Pargendler, j.22.03.2007).

${ }^{103}$ Para Fernando Büscher von Teschenhausen Eberlin, a interpretação finalista aprofundada deve ser aplicada e é válido transcrever suas palavras: “A interpretação finalista aprofundada deve sim ser aplicada, mas é imperioso que se verifique se a situação colocada em debate efetivamente revela uma relação de consumo (aquisição/utilização de um produto ou serviço) ou mera relação civil (como, por exemplo, um contrato de fornecimento), bem como se há verdadeira vulnerabilidade de um contratante em relação a outro.

A aplicação indiscriminada das regras consumeristas a quem não é consumidor acabaria por banalizar a aplicação do CDC, enfraquecendo seus institutos e prejudicando o seu destinatário verdadeiro." (EBERLIN, Fernando Büscher von Teschenhausen. op. cit., p. 13). 
A responsabilidade por vício trata de questões de qualidade e quantidade que tornem o produto ou o serviço inadequado para o fim a que se destina ou lhe diminua o valor. Neste caso, o que legitima o consumidor a pleitear a reparação é a imprestabilidade do produto ou serviço.

Já no caso da responsabilidade por fato tutela os danos causados por defeitos. É aplicável apenas aos casos que tenham causado problemas ou anomalias do produto ou do serviço que comprometam a segurança deles legitimamente esperada. O defeito será invariavelmente um vício agravado pela existência de risco à segurança do consumidor.

\subsubsection{Do papel do consumidor}

O consumo é, sem dúvida, o objetivo final em qualquer atividade econômica para satisfazer as necessidades, tendo, o consumidor, papel de destaque nesse processo. Com efeito, não pode ser relegado a plano inferior. ${ }^{104}$

O papel do consumidor é de tamanha importância que pode determinar a quantidade que um bem pode ser vendido aos vários preços e também quais os tipos que podem ser vendidos.

Os desejos dos homens são insaciáveis e ao mesmo tempo sabemos que a satisfação desses desejos é restringida pelo limitado poder de compra de cada indivíduo. ${ }^{105}$

\footnotetext{
${ }^{104}$ Nesse sentido, Myron Umbreit, Elgin Hunt e Charles Kinter exemplificam: “A senhora x, uma dona de casa, entra na mercearia da esquina para comprar um pão. Esta ação é, em si, muito simples, mas, para fazer que a senhora x compre esse pão, torna-se necessário o desenrolar de uma cadeia inteira de acontecimentos. O agricultor deve ter limpado e cultivado a terra, plantado e colhido o trigo, para depois vendê-lo ao negociante de cereais. Este, por sua vez, deve tê-lo vendido ao moageiro, que o transformou em farinha, adquirida pelo panificador. Este, por sua vez, preparou e vendeu o pão ao merceeiro, que o tem, agora, pronto para vender à senhora x." (UMBREIT, Myron; HUNT, Elgin; KINTER, Charles. Economia: princípios e problemas. 3. ed. Rio de Janeiro: Fundo de Cultura, 1957. p. 94).

${ }^{105}$ Newton de Lucca ressalta que: "Torna-se facilmente observável, assim, o seguinte fenômeno típico da atualidade: enquanto os consumidores de alto poder aquisitivo têm à sua disposição a mais variada gama de opções, das quais evidentemente nem se podem dar conta, havendo inevitável desperdício em razão do excesso, a população carente se vê inconscientemente impelida a consumir bens que estão muito acima de suas reais condições financeiras.

Os sentimentos de frustração, de inconformismo e de revolta, oriundos das notórias dificuldades ou mesmo da completa impossibilidade de aquisição desses bens, para uso próprio ou dos membros de sua família, têm gerado a crescente explosão de violência social, principalmente nos grandes centros urbanos, nos quais uma desigualdade gritante e perversa, aliada à superpopulação de tais cidades, atua como poderoso fator estimulante da criminalidade.

Assim, aquela famosa dicotomia - que tanta celeuma iria gerar nos espíritos mais reacionários - entre necessidades 'verdadeiras', de um lado, e 'falsas', de outro, tão bem posta em relevo pelo gênio de Marcuse, não pode deixar de ser tida, agora, como evidente, mesmo por aqueles mais ardorosos defensores
} 
A quantidade de bens que realmente um indivíduo pode comprar depende diretamente de dois fatores - o volume de renda monetária e os preços que deve pagar pelos bens. Com a moderna economia industrial o consumidor fica muitas vezes confuso com a infinita variedade de bens semelhantes vendidos a preços tão distintos. O poder de compra deve ser compatível à capacidade física de produzir bens, caso contrário ou o consumidor estará insatisfeito com a falta de opções de produtos ou as fábricas ficarão ociosas, pois os bens não poderiam ser vendidos a preços que cobrissem os custos de produção.

O progresso nos métodos de produção foi constante, de modo que foi possível produzir mais e melhores artigos a um custo constantemente decrescente. É válido lembrar, entretanto, que ainda não foi possível evitar períodos de depressão, como o período da década de 30 e o atual, e que o problema do desemprego originou uma crise mundial. ${ }^{106}$

Outro fator que afeta o poder de compra do consumidor é a falta de conhecimento do produto. Muitas vezes o consumidor não está em condição de fazer uma escolha racional, às vezes por falta de tempo, mas na maioria das vezes por falta de capacidade de determinar se o produto corresponde ao preço solicitado. $\mathrm{O}$ consumidor tende a depender do preço para utilizar como critério de qualidade, ou seja, o preço torna-se base para julgamento da qualidade.

Aspecto importante que induz o consumidor na escolha do produto é o método de venda, desde a publicidade até as condições de pagamento. O gasto com publicidade é significativo tanto para o produto novo informando ao público de sua existência quanto para um produto que já é conhecido, mas o produtor deseja dar a impressão de que a sua marca é superior às demais existentes no mercado.

da mística do mercado e mesmo pelos fanáticos adeptos do capitalismo irresponsável que, num misto de arrogância e cinismo, chegavam a falar, grotescamente, em ditadura do consumidor...

Concordo, pois, irrestritamente, com a conclusão daquele autor, no sentido de que "a maioria das necessidades comuns de descansar, distrair-se, comportar-se e consumir de acordo com os anúncios, amar e odiar o que os outros amam e odeiam, pertence a essa categoria de falsas necessidades". (DE LUCCA, Newton. op. cit., p. 53-55).

${ }^{106}$ Vale citar Myron Umbreit, Elgin Hunt e Charles Kinter que na década de 50 já haviam previsto que novamente aconteceria uma nova crise econômica: "Mesmo agora não há certeza de que os americanos serão capazes de evitar depressões no futuro. Todavia, desde o começo da Segunda Guerra Mundial, tiveram, com apenas pequenas interrupções, um elevado e crescente nível de produção e emprego. Também, recentemente, os economistas estão dedicando cada vez mais atenção ao ciclo econômico e ao problema de manter a renda do consumidor e o emprego, em níveis satisfatórios. É possível, portanto, que se esteja estabilizando a economia de maneira mais satisfatória do que no passado, e de que, agora, haja conhecimento suficiente das causas das flutuações econômicas, que torna possível, agindo-se em tempo, evitar a repetição de sérias depressões." (UMBREIT, Myron; HUNT, Elgin; KINTER, Charles. op. cit., p. 96). 
Diversos fatores influenciam o consumidor na hora de escolher o produto a ser adquirido, mas, indubitavelmente, a renda monetária e o preço dos bens são fundamentais.

Dessa forma, a produção não é um fim em si mesma e, indiscutivelmente, toda produção tem, como objetivo final, a satisfação dos desejos dos consumidores. Há que se ponderar ainda que a liberdade de escolha dos consumidores não é absoluta é limitada por várias maneiras, desde o costume ou hábito, até pela intervenção do Estado, em alguns casos.

Outrossim, não basta aumentar a capacidade técnica da produção se os consumidores não forem capazes de comprar os bens.

\subsection{Do conceito de fornecedor}

$\mathrm{O}$ artigo $3^{\circ}$ do CDC dispõe que fornecedor é toda pessoa física ou jurídica, pública ou privada, nacional ou estrangeira, bem como os entes despersonalizados, que desenvolvem atividade de produção, montagem, criação, construção, transformação, importação, exportação, distribuição ou comercialização de produtos ou prestação de serviços.

O que caracteriza a pessoa como fornecedor é o desenvolvimento de atividades tipicamente profissionais, excluindo-se os contratos firmados entre dois consumidores, mas, por outro lado, será considerado fornecedor, também sem uma relação direta; isso significa dizer que haverá sua responsabilização, mesmo no âmbito da responsabilidade extracontratual. ${ }^{107}$

\footnotetext{
${ }^{107}$ Claudia Lima Marques ensina que: $\mathrm{O}$ art. $3^{\circ}$ do $\mathrm{CDC}$ bem especifica que o sistema de proteção do consumidor considera como fornecedores todos os que participam da cadeia de fornecimento de produtos $\mathrm{e}$ da cadeia de fornecimento de serviços (o organizador da cadeia e os demais partícipes do fornecimento direto e indireto, mencionados genericamente como 'toda pessoa física ou jurídica, pública ou privada, nacional ou estrangeira, bem como os entes despersonalizados, que desenvolvem atividades de (...) prestação de serviços'), não importando sua relação direta ou indireta, contratual ou extracontratual, com o consumidor.

Em outras palavras, o CDC menciona fornecedores, pensando em todos os profissionais da cadeia de fornecimento (de fabricação, produção, transporte e distribuição de produtos e da criação e execução de serviços) da sociedade de consumo. O parágrafo único do art. $7^{\circ}$ do $\mathrm{CDC}$ bem especifica que há mesmo solidariedade nesta cadeia: "Tendo mais de um autor a ofensa, todos responderão solidariamente pela reparação dos danos previstos nas normas de consumo." (UMBREIT, Myron; HUNT, Elgin; KINTER, Charles. op. cit., p. 82).
} 
Segundo Newton de Lucca, entende-se como fornecedor o participante do ciclo produtivo-distributivo, devendo exercer a sua atividade econômica de forma organizada, de forma empresarial autônoma, sem depender de terceiros para exercê-la. E o autor exemplifica ao lembrar a discussão sobre a aplicabilidade do CDC à atividade bancária, pois muito pouco se analisou sobre a subsunção dos bancos ao conceito de fornecedor, mas, ao contrário, muito se debateu sobre o enquadramento dos clientes na qualidade de consumidores. ${ }^{108}$

Adiante o autor distingue ato de atividade. Na primeira hipótese, não há que se falar em atividade empresarial, posto que o ato isolado não é praticado de forma organizada e sistemática, enquanto, na segunda atividade econômica organizada para a produção ou circulação de bens e de serviços é, por excelência, o traço característico do empresário. ${ }^{109}$

Sylvio Marcondes, sobre a diferenciação entre ato e atividade, observa: "Ora, não obstante serem os atos negociais facultados a todas as pessoas e, por essa razão, cabíveis num direito objetivo comum, é certo que a sua prática, quando continuadamente permanente, cria, em torno desta, uma série de relações interdependentes que, conjugando o exercício coordenado dos atos, o transubstancia em atividade."110

Marlon Tomazette define que:

"a empresa é a 'atividade econômica organizada de produção ou circulação de bens ou serviços', ou seja, equivale ao perfil funcional da teoria de Alberto Asquini.

Trata-se de atividade, isto é, do conjunto de atos destinados a uma finalidade comum, que organiza os fatores da produção, para produzir ou fazer circular bens ou serviços. Não basta um ato isolado, é necessária uma sequência de atos dirigidos a uma mesma finalidade, para configurar a empresa.

E não se trata de qualquer sequência de atos. A economicidade da atividade exige que a ela seja capaz de criar novas utilidades, novas riquezas, afastando-se as atividades de mero gozo. Nessa criação de novas riquezas, pode-se transformar matéria-prima (indústria), como também pode haver a interposição na circulação de bens (comércio em sentido estrito), aumentando o valor deles."111

\footnotetext{
${ }^{108}$ DE LUCCA, Newton. op. cit., p. 138. Atualmente, o STF dirimiu a controvérsia para subsumir a atividade bancária ao CDC, ainda que com restrições.

${ }^{109}$ Id. Ibid., p. 140.

${ }^{110}$ MARCONDES, Sylvio. Problemas de direito mercantil. São Paulo: Max Limonad, p. 129 e ss.

${ }^{111}$ TOMAZETTE, Marlon. Direito societário. São Paulo: Juarez de Oliveira, 2004. p. 6-7.
} 
Nos termos do artigo 3, o CDC refere-se expressamente ao fornecedor como aquele que desenvolve uma atividade econômica de maneira autônoma', sendo possível definir esta como o conjunto de atos destinado a essa finalidade.

\subsection{Do dever de informação}

O direito de informação tem alcance constitucional e legal, sendo seus dispositivos analisados por diferentes enfoques. O inciso XIV do artigo $5^{\circ}$ da $\mathrm{CF} / 88$ garante a qualquer cidadão a liberdade de buscar e obter informação. Para o presente trabalho, merece atenção o campo do consumidor e invoca-se o direito de ser informado.

No CDC o dever de informar está previsto no artigo 31 e passa a representar verdadeiro dever básico a fim de se obter a harmonia e a transparência das relações de consumo. $^{112}$

Com efeito, os produtos colocados no mercado de consumo não poderão acarretar riscos à saúde ou segurança dos consumidores, exceto os considerados previsíveis, em razão de sua natureza e fruição, estando os fornecedores, em qualquer hipótese, obrigados a dar informações necessárias e adequadas a seu respeito. As informações devem ser claras, ostensivas e inteligíveis, atendendo ao princípio da transparência que norteia as relações de consumo.

Papel importante são as listas dos ingredientes, informações nutricionais e demais dados são práticas em diversos mercados, pois se, de um lado, os consumidores têm direito à informação, por outro, os fornecedores têm o dever de informar. ${ }^{113}$

\footnotetext{
${ }^{112}$ Art.31. A oferta e apresentação de produtos ou serviços devem assegurar informações corretas, claras, precisas, ostensivas e em língua portuguesa sobre suas características, qualidades, quantidade, composição, preço, garantia, prazos de validade e origem, entre outros dados, bem como sobre os riscos que apresentam à saúde e segurança dos consumidores. $\mathrm{O}$ rol de características previstas no dispositivo são meramente exemplificativas, estabelece características físicas do produto, a sua repercussão econômica e com a saúde do consumidor.

${ }^{113}$ Vale relatar um caso de intoxicação de consumidores de um suplemento alimentar, produzido pela companhia Shhowa Denko, com altos teores de triptofano, um aminoácido natural considerado essencial na alimentação humana. O composto foi obtido por fermentação de uma bactéria GM pela inclusão de genes de um microrganismo do solo. A ocorrência assumiu um nível de tragédia, no oeste dos Estados Unidos, causando a morte de 37 pessoas e intoxicando cerca de 5 mil outras, tornando 1.500 delas incapacitadas. O problema, no entanto, restringia-se à presença de uma toxina produzida pelo microrganismo que não havia sido detectada e removida do meio que continha a mistura de aminoácidos. O caso ficou conhecido como síndrome de eosinofilia-mialgia (EMS), devido às evidências e aos sintomas iniciais dos pacientes mediante
} 
O problema maior diz respeito à inexistência de informações precisas, testes concretos e pesquisa aprofundada que possa identificar a dimensão do perigo e risco que o consumidor está correndo.

O dever de informar é um dever anexo à boa-fé, com base na proteção ao consumidor, tendo em vista a desigualdade entre as partes.

No direito do consumidor, tanto na esfera extracontratual quanto contratual, o direito à informação traduz-se em um dever anexo, que deve estar presente em todas as relações.

O direito à informação insere-se nos direitos fundamentais e apenas foi possível consagrá-lo a tal patamar quando se percebeu a dimensão humanística para além das concepções puramente econômicas. ${ }^{114}$

Sem dúvida, o dever de informar está diretamente relacionado aos princípios da transparência e da veracidade. O primeiro requer do fornecedor todas as informações sobre os riscos à pessoa ou aos bens, composição dos produtos, qualidade, vantagens e desvantagens, já o princípio da veracidade impede o fornecedor de enganar, ludibriar o consumidor; o fornecedor não pode transmitir informações falsas.

O dever de informação é de extrema importância no estudo do risco do desenvolvimento, pois não se pode negar que o fornecedor, apenas pelo fato de ter introduzido o produto no mercado sem informar sobre a possibilidade de eventual dano, possa ter violado esse dever, na medida em que na época de sua introdução não havia qualquer pesquisa que comprovasse eventual dano. ${ }^{115}$

elevado número de células sangüíneas, eosinófilos, num quadro de dores musculares, paralisia e problemas neurológicos, entre outros (Fangan, s/d).

O FDA liberou a comercialização sem análise toxicológica preliminar, pois a empresa de origem japonesa tinha boa conceituação no mercado americano, possuía outros suplementos alimentares obtidos de preparações diferentes sem haver qualquer tipo de contestação sobre a qualidade ou a segurança desses suplementos. Elucida-se ainda que o produto foi considerado substancialmente equivalente a outras formulações existentes e que os problemas resultaram do aparecimento de pelo menos um contaminante tóxico, o 1,1'- etilideno bis (1-triptofano), ou apenas EBT, presente em menos do que 0,1\% do peso final da fórmula. Apesar de o aminoácido ativo não ser propriamente o responsável pelos danos causados, estabeleceu-se o vínculo do produto comercial ao conceito amplo de biotecnologia. (Manual de Biossegurança, Barueri - SP, Manole, 2002, p. 260).

${ }^{114}$ LOBO, Paulo Luiz Netto. A informação como direito fundamental do consumidor. Revista de Direito do Consumidor, São Paulo, n. 37, p. 62, jan./mar. 2001.

${ }^{115}$ A contrário senso, o julgado considerou que o fornecedor violou o dever de informar em virtude descrição insuficente do bem: "Promessa de compra e venda - Anulação - Descrição insuficiente do bem - Erro Violação ao dever de informar. Constitui violação ao dever de informar a omissão, no contrato de promessa de compra e venda de unidade a ser construída, sua exata localização, induzindo em erro os promitentes compradores. Hipótese em que o contrato foi firmado quando ainda não procedida a individuação da 
Questionou-se muito sobre o dever de informar ou não sobre a característica transgênica (organismo geneticamente modificado - OGM) de um alimento ou um ingrediente de um alimento.

Frise-se que no Brasil a comercialização dependerá de pedido da Comissão Técnica Nacional de Biossegurança - CNTBio a CNBS, esta realizará a análise quanto a conveniência e oportunidade socioeconômica de interesse nacional os pedidos de liberação para uso comercial de OGM e seus derivados, nos termos do inciso II, do artigo $8^{\circ}$ da Lei $11.105 / 2005$.

O Decreto 4.680, de 2003, regulamenta o direito à informação do consumidor quanto aos alimentos e ingredientes alimentares destinados ao consumo humano ou animal que contenham ou sejam produzidos a partir de organismos geneticamente modificados. ${ }^{116}$

O dever de informar quanto à utilização no produto ou organismos geneticamente modificados não se restringe ao fato de ser apenas direito humano do consumidor, mas também porque o consumidor tem a liberdade de escolha entre produtos com ingredientes da natureza e com ingredientes que tiveram seus genes modificados por intervenção humana artificial. ${ }^{117}$

unidade. Recurso provido. (TJRS - 17 Câm. - AP. Cív. 198001307 - Rel. Des. Maria Isabel de Azevedo Souza -j.18.08.1998).

${ }^{116}$ Vale transcrever o artigo 2 do decreto: "Na comercialização de alimentos e ingredientes alimentares destinados ao consumo humano ou animal que contenham ou sejam produzidos a partir de organismos geneticamente modificados, com presença acima do limite de um por cento do produto, o consumidor deverá ser informado da natureza transgênica desse produto."

${ }^{117}$ Claudia Lima Marques elucida: Em outras palavras, são duas as fontes do direito de informação do consumidor:em virtude dos eventuais riscos que estas modificações genéticas podem trazer (direito à proteção da dignidade da pessoa humana, arts. $1^{\circ}$, III, e $5^{\circ}$, XXXII, da CF $/ 88 \mathrm{c} / \mathrm{c}$ arts. $6^{\circ}$, III, e 31 do CDC), mas também pelo simples direito de escolha do cidadão consumidor (direito de autonomia da vontade $\mathrm{e}$ livre iniciativa do cidadão, direito de livre escolha no mercado de consumo, art.170, caput e V, da CF/1988 c/c arts. $6^{\circ}$, II, e 31 do CDC).

Assim, se os transgênicos são ou não um risco para a saúde (aqui há que se prevenir os riscos e evitar utilizar os consumidores brasileiros como cobaias, o que acarretaria eventuais danos futuros, cuja reparação é assegurada pelo art. $6^{\circ}$, VI, do CDC), cabe à ciência e ao Estado definir qual porcentagem de transgenia pode causar mal (1\% da Europa, $4 \%$ do Dec. 3.871/2001, já revogado). Importa, porém, frisar que esta discussão não afeta, nem diminui o direito do consumidor de escolher livremente ( e receber informação na embalagem sobre o tema), a fim de não dar a seu filho, por exemplo, produtos geneticamente modificados. Daí o dever de informar no rótulo qualquer uso de OGM, qualquer uso possível e eventual (contaminações industriais com ingredientes são comuns nestes casos), em qualquer quantidade, como hoje se informa todos os ingredientes, corantes etc. Aqui, o direito do consumidor em ser informado e o dever de informar dos fornecedores é o mesmo dos outros ingredientes, sem privilégios para os agricultores ou para a indústria brasileira, cuja utilização de transgênicos é também decisão política e econômica, mas sempre com cumprimento dos deveres jurídicos de boa-fé e lealdade informativa." (MARQUES, Claudia Lima; BENJAMIN, Antônio Herman; MIRAGEM, Bruno. Comentários ao Código de Defesa do Consumidor. 2. ed. São Paulo: Ed. Revista dos Tribunais, 2006. p. 483). 
Ressalve-se, também, que o art. 220 da Constituição da República estabeleceu, em $\S 4^{\circ}$, que, à lei federal, competirá fixar as restrições à propaganda comercial do tabaco. O Ministério da Saúde, seguindo a lei e por meio de portarias assumiu o dever de informar e passou a expressar tudo que entendeu necessário divulgar sobre o uso do cigarro. Sem dúvida, por força desse procedimento o fornecedor restou liberado de fornecer outras informações sobre eventuais riscos do produto, pois o próprio governo federal, mediante o Ministério da Saúde, de forma específica, avocou para si o cumprimento do dever de informar, não só dispensou, mas até mesmo impediu que essa atividade fosse exercida pelo particular.

Indiscutivelmente, o dever de informar se guia pela expectativa do consumidor em relação ao produto, ou seja, sendo o risco conhecido não há necessidade de mais informação, uma vez que os fatos conhecidos não exigem informação.

Nessa seara, há que se fazer uma distinção entre o dever de informar e a publicidade, uma vez que esta tem por finalidade atrair os consumidores e não de transmitir informações sobre o conhecimento da segurança do produto ou serviço. Em suma, a publicidade é apenas uma das formas de transmissão de informações, só não podendo ser enganosa ou abusiva. ${ }^{118}$

\footnotetext{
${ }^{118}$ Mirta Morales assevera que: "El derecho del consumidor por su parte, debe dotar de fuerza vinculante a la oferta masiva, estipulando normas de regulación sobre el uso de la publicidad como medida preventiva frente a eventuales daños futuros." (MORALES, Mirta. Un estudio comparativo de la protección legislativa del consumidor en el ambito interno de los paises del Mercosur. Rio de Janeiro: Renovar, 2006). Em tradução livre: "O direito do consumidor, de sua parte, deve dotar de força vinculante à oferta massiva, estipulando normas de regulação sobre o uso da publicidade como medida preventiva em face de eventuais danos futuros."
} 


\title{
CAPÍTULO IV. DA RESPONSABILIDADE PELO FATO DO PRODUTO
}

\author{
SUMÁRIO: 4. - DA RESPONSABILIDADE CIVIL - 4.1. DA \\ RESPONSABILIDADE PELO FATO DO PRODUTO - 4.1.1 DO DEFEITO - 4.2. \\ DO NEXO DE CAUSALIDADE - 4.2.1. DA FLEXIBILIZAÇÃO DO NEXO DE \\ CAUSALIDADE - 4.3. DAS EXCLUDENTES DA RESPONSABILIDADE - 4.3.1. \\ DAS EXCLUDENTES DE RESPONSABILIDADE NO ÂMBITO DO CDC.
}

\section{Da responsabilidade civil}

O instituto da responsabilidade civil sofreu grande evolução nos últimos tempos, o que inclusive acarretou a necessidade de a doutrina e a jurisprudência estarem adiante da própria legislação.

Indiscutivelmente, nenhum outro instituto no ordenamento jurídico passou por alterações tão profundas, decorrentes da industrialização, o que levou à busca de alterações estruturais. $^{119}$

É preciso ter em mente que a atribuição de responsabilidade é uma forma de organizar o fluxo dos acontecimentos. Ao se imputar responsabilidade, interrompe-se uma cadeia complexa de relações de causalidade em certo ponto para atribuir as consequências

\footnotetext{
${ }^{119}$ Anderson Schreiber observa: "Poucos campos do direito privado passaram por alterações tão profundas nas últimas décadas quanto à Responsabilidade Civil. Para muito além de alterações e inovações estruturais, a própria função da Responsabilidade Civil encontra-se em debate. Concebida pelo liberalismo jurídico, que marcou as codificações europeias dos séculos XVIII e XIX, como um mecanismo de solução de conflitos interindividuais, a Responsabilidade Civil ganhou uma dimensão social inesperada.

A industrialização trouxe, para além da multiplicação dos danos efetivamente produzidos na sociedade, as primeiras evidências de que a Responsabilidade Civil precisaria alcançar um papel menos intimista que aquele proposto pelos juristas da Modernidade. $\mathrm{O}$ aumento do número de acidentes conduziu a um ataque maciço contra a noção de 'culpa', até então tida como elemento nuclear da Responsabilidade Civil. Era preciso facilitar a reparação dos danos, livrando a vítima da tormentosa demonstração da culpa, chamada, não por acaso, de probatio diabolica. Bem mais que uma questão probatória, começava a entrar em xeque a própria função da responsabilidade Civil em uma sociedade que se prometia marcada pela massificação progressiva das relações sociais e econômicas.

Objeto do 'mais intenso dos ataques doutrinários que talvez se tenha registrado na evolução de um instituto jurídico', a culpa cedeu gradativamente. De um lado, os tribunais facilitaram, por toda parte, a sua demonstração, com presunções de culpa que ganharam, em muitas situações, ares de presunção absoluta. De outro, a chamada teoria do risco difundiu-se amplamente, propondo um sistema objetivo de responsabilidade, que dispensasse qualquer valoração do cuidado empregado pelo sujeito causador do dano. Seu sucesso foi inegável: a responsabilidade objetiva passou a ser acolhida pela maior parte dos ordenamentos de civil law e commom law, estendendo-se a uma série tão ampla de situações que se torna cada vez mais difícil identificar o risco como seu exclusivo fundamento." (SCHREIBER, Anderson. Flexibilização do nexo causal em relações de consumo. In: MARTINS, Guilherme Magalhães (Coord.). Temas de direito do consumidor. Rio de Janeiro: Lúmen Juris, 2010. p. 30-31).
} 
de dado evento a uma pessoa determinada, a quem se impõe o dever de indenizar um dano. $^{120}$

Josserand, que foi um dos primeiros a trazer a noção de teoria do risco, afirmava que:

temos sede de justiça, isto é, de equilíbrio jurídico, e, quando acontece um desastre, procuramos logo o responsável: queremos que haja um responsável; já não aceitamos docilmente os golpes do destino e, sim, pretendemos determinar a incidência definitiva. Ou, se quiserem, o acidente já não nos aparece como coisa do destino, mas como ato, direto ou indireto, do homem. ${ }^{121}$

A origem da palavra responsabilidade vem do latim re-spondere - ideia de segurança ou garantia de restituição. O sentido etimológico exprime a ideia de obrigação, encargo e contraprestação; no aspecto jurídico a violação de um dever jurídico traz consigo a obrigação de reparar e de restabelecer a harmonia quebrada.

O instituto é um fenômeno social, uma vez que o sujeito da ação ou omissão que resulta em dano deve suportar as consequências. É uma regra básica de sobrevivência da sociedade, que foi expressa pelo Direito Romano através da máxima neminem laedere.

Todo o bem na vida civil deve estar garantido contra quaisquer ofensas. Trata-se de um dever social e particular de cada um com o seu próximo. É justa a sociedade na qual não se deixam prosperar os danos causados seja à honra, seja à propriedade. ${ }^{122}$

Para a responsabilidade civil fundada na culpa, o dano só acarretaria obrigação de reparar para aquele que o pratica. ${ }^{123} \mathrm{O}$ Código Civil de 1916 fundou, basicamente, o seu sistema na responsabilidade civil subjetiva, nos termos do artigo 159, que tinha a culpa lato sensu como elemento fundamental. A responsabilidade se configuraria com a presença da culpa. O dever de indenizar dependia, necessariamente, da demonstração do comportamento culposo do agente causador do prejuízo.

Com efeito, a culpa ainda é elemento importante para a responsabilidade, entretanto, em virtude da preocupação em não deixar vítimas desamparadas, tornou-se necessária a

\footnotetext{
${ }^{120}$ PUSCHEL, Flavia Portella. A responsabilidade por fato do produto no $C D C$ : acidentes de consumo. São Paulo: Quartier Latin, 2006. p. 41.

${ }^{121}$ Evolutions et actualités, Sirey, Paris: Revista Forense, vol.86, p. 548, tradução do Raul Lima apud DIAS, José de Aguiar. Da responsabilidade civil. 11. ed. atual. de acordo com o Código Civil de 2002, e aumentada por Rui Berford Dias. Rio de Janeiro: Renovar, 2006.

${ }^{122}$ HIRONAKA, Giselda Maria Fernandes. Responsabilidade pressuposta. Belo Horizonte: Del Rey, 2005. p. 87.

${ }^{123}$ DIAS, José de Aguiar. op. cit., p. 741.
} 
construção de uma responsabilidade sem culpa, prevista principalmente no parágrafo único do artigo 927 do Código Civil atual, como cláusula geral.

A grande mudança ocorrida tem por finalidade precípua o dever de indenizar a vítima, independentemente da prova do ato ilícito.

A sociedade atual fez com que a reparação da vítima não dependesse, obrigatoriamente, da identificação do causador do ato realizado de forma negligente ou imprudente, como previa o artigo 159 do CC de 1916, e no Código atual, prevista no artigo 186. Essa mudança de enfoque, originariamente, atribuída ao agente que cometeu o ato ilícito, objetiva o mais amplo ressarcimento à vítima dos eventos danosos.

Certo é que os tradicionais parâmetros para o sistema da responsabilidade não são mais exclusivamente a antijuridicidade e a culpabilidade.

A ideia de a responsabilidade apenas ser invocada como sanção por falta cometida teve que ser rejeitada, pois não condizia mais com a realidade. Foi preciso uma busca por soluções alternativas paralelamente à rigidez dos textos legais.

Outrossim, por força da periculosidade de inúmeras atividades e do desenvolvimento tecnológico a tradicional responsabilidade subjetiva, informada pela teoria da culpa, mostrou-se insuficiente para as relações jurídicas na atual sociedade. ${ }^{124}$

A teoria do risco foi adotada porque é desvinculada da valoração da conduta do sujeito. Os requisitos da responsabilidade objetiva não têm como elemento indispensável a culpa, mas sim o exercício de certa atividade e o nexo de causalidade entre o dano e a atividade. Dessa forma, a responsabilidade se volta para a vítima e não para o agente.

Entretanto, a responsabilidade civil objetiva deve ser restrita às hipóteses previstas ex lege e às atividades de risco; quem tira proveito de certa atividade deveria assumir os riscos dela decorrentes, o que, de certa forma, também parece insuficiente para abranger todas as hipóteses.

\footnotetext{
${ }^{124}$ Nesse sentido, Alvino Lima: "Os perigos advindos dos novos inventos, fontes inexauríveis de uma multiplicidade alarmante de acidentes, agravados pela crescente impossibilidade, tanta vez, de se provar a causa do sinistro e a culpa do autor do ato ilícito, forçaram as portas, consideradas, até então, sagradas e inexpurgáveis da teoria da culpa, no sentido de se materializar a responsabilidade, numa demonstração eloqüente e real de que o Direito é, antes de tudo, uma ciência nascida e feita para disciplinar a própria vida." (LIMA, Alvino. Culpa e risco. 2. ed. rev.e atual. pelo Prof.Ovídio Rocha Barros Sandoval. São Paulo: Ed. Revista dos Tribunais, 1998. p. 16).
} 
Será objetiva a responsabilidade do causador do dano quando esta decorrer de atividade normalmente desenvolvida por ele ou quando estiver previsto em lei. Quem aufere os lucros deve suportar os riscos.

A potencialidade lesiva da atividade deve ser de grau superior ao normal para que a atividade seja considerada "de risco", de modo a viabilizar a responsabilização objetivamente.

$\mathrm{Na}$ verdade, atualmente, o que se procura evitar é que os direitos sejam violados, por isso que, para garanti-los, não importa a natureza e seu fundamento, mas sim o princípio do neminem laedere.

Para a teoria clássica, a responsabilidade civil se assenta em três aspectos: o dano, a culpa e a relação de causalidade entre o ato ilícito e o dano. Esses requisitos ainda levam à caracterização do instituto, entretanto não se pode olvidar o risco como pressuposto para a responsabilidade civil objetiva.

A existência de inúmeros danos ressarcíveis, capazes de colocar em risco os próprios fundamentos éticos e sociais que deram origem à responsabilização, leva à conclusão de que nem todo dano pode ou deve ser reparado.

Vale mencionar a inteligência do artigo 944 do Código Civil que reduz a indenização com base no grau de culpa. A lei não olha para o causador do prejuízo, mas sim para o dano a fim de avaliar a sua extensão. ${ }^{125}$ Nesse comando é facultado ao juiz basear-se com parcimônia, ou seja, de acordo com o grau de culpa.

Certamente, no campo da reparação, prefere-se a discricionariedade à arbitrariedade. O nexo causal tem papel fundamental, como filtro para as demandas dignas de análise pelo Judiciário, para que não haja a ampliação excessiva da responsabilização. ${ }^{126}$

\footnotetext{
${ }^{125}$ Confira-se o dispositivo: “Art.944. A indenização mede-se pela extensão do dano. Parágrafo único. Se houver excessiva desproporção entre a gravidade da culpa e o dano, poderá o juiz reduzir, equitativamente, a indenização".

${ }^{126}$ Gustavo Tepedino elucida: "Diante do novo panorama legislativo, doutrinário e jurisprudencial, polarizouse o discurso jurídico entre aqueles que identificam na ampliação do dever de reparar uma vitória em si mesma, atribuindo ao Estado e aos empresários praticamente todos os ônus decorrentes da atividade produtiva; e, de outra parte, os que denunciam uma indústria de danos, propiciadora de verdadeiro enriquecimento sem causa." (TEPEDINO, Gustavo. O futuro da responsabilidade civil. In: de direito civil. Rio de Janeiro: Renovar, 2009. t. 3, p. 409). . Temas
} 


\subsection{Da responsabilidade pelo fato do produto}

Inquestionavelmente, todos as pessoas são consumidores, incluindo as pessoas jurídicas, gerando, consequentemente, milhares de relações de consumo que podem causar danos à vida, à saúde física ou psíquica e ao patrimônio de terceiros por produtos com defeitos de segurança. Na verdade, o âmbito de atuação da responsabilidade pelo fato do produto é o dano causado à integridade físico-psíquica da vítima e a bens outros que não o próprio produto defeituoso, na medida em que não atende à legítima expectativa do consumidor com relação à sua segurança. ${ }^{127}$

Para Aguiar Dias, a expressão 'responsabilidade pelo fato do produto e do serviço' não refletiria com exatidão o enfoque do direito do consumidor. Para o autor, é incongruente utilizar essa expressão, na medida em que a coisa não é capaz de fatos. ${ }^{128}$

Claudia Lima Marques ressalta que o melhor é utilizar responsabilidade pelos acidentes de consumo, já que a terminologia responsabilidade pelo fato do produto enfatizaria o elemento material causador da responsabilidade, enquanto, ao contrário, aquela destacaria o elemento humano consequencial. E conclui que o dado fundamental não é a origem do fato (do produto ou serviço), mas sim a localização humana de seu resultado (o acidente de consumo). A rigor, só se voltaria para o fenômeno material inerente ao produto (o defeito) quando tem seu interesse despertado pela sua habilidade para causar o fenômeno humano (o acidente de consumo). ${ }^{129}$

Para a autora, o contrato de consumo seria instrumento jurídico para a realização dos legítimos interesses do consumidor, exigindo, então, um regramento legal rigoroso e imperativo de seus efeitos. ${ }^{130}$

\footnotetext{
${ }^{127}$ Sergio Cavalieri observa: "E assim entendo porque, tendo o Código de Defesa do Consumidor, como vimos, estabelecido uma disciplina única e uniforme para todas as relações de consumo, necessariamente terá que ser aplicado em toda e qualquer área do Direito onde elas ocorrem, e hoje, tudo ou quase tudo tem a ver com o consumidor: a saúde, a segurança, os transportes, a alimentação, medicamentos, moradia, e assim por diante. Somos mais de 160 milhões de consumidores no Brasil, sem contar as pessoas jurídicas, gerando diariamente outros tantos milhões de relações de consumo. Vale dizer, a nova disciplina do Código de Defesa do Consumidor alcança as relações de consumo onde quer que elas venham a ocorrer." (CAVALIERI FILHO, Sergio. Programa de responsabilidade civil. 6. ed. São Paulo: Malheiros, 2006. p. 487).

${ }^{128}$ DIAS, José de Aguiar. op. cit., p. 578.

${ }^{129}$ MARQUES, Claudia Lima. op. cit., p. 112.

${ }^{130}$ Claudia Lima Marques pondera: "A função social do contrato, reconhecida na nova teoria contratual, transforma o contrato de consumo, de simples instrumento jurídico para o movimento das riquezas do mercado, em instrumento jurídico para a realização dos legítimos interesses do consumidor, exigindo, então, um regramento legal rigoroso e imperativo de seus efeitos.
} 
Nos acidentes de consumo o dano é caracterizado pelo fato de ter atingido a integridade físico-psíquica da vítima; nesse sentido é possível afirmar que o dano ultrapassa os limites do produto ou serviço. Com efeito, os produtos e serviços colocados no mercado têm, além de uma função econômica, um objetivo de segurança.

No conceito de qualidade por insegurança encontram-se, dessa forma, dois elementos: a desconformidade com uma expectativa legítima e a capacidade de provocar acidentes, pois o seu fundamento é o dever de segurança ou de cuidados dos fornecedores ao colocarem os produtos e serviços no mercado brasileiro.

Em outro enfoque, questiona-se se houve relação entre a vítima e o produto e não se houve relação entre fornecedor e consumidor, na medida em que o bystander é incluído no conceito de consumidor.

A Seção II do CDC, que trata da responsabilidade do fabricante pelo fato do produto e do serviço, disciplina no artigo 12 que: "O fabricante, o produtor, o construtor, nacional ou estrangeiro, e o importador respondem, independentemente de culpa, pela reparação dos danos causados aos consumidores por defeitos decorrentes de projeto, fabricação, construção, montagem, fórmulas, manipulação, apresentação ou acondicionamento de seus produtos, bem como por informações insuficientes ou inadequadas sobre sua utilização e riscos."

\footnotetext{
A manifestação da vontade do consumidor é dada almejando ele alcançar determinados fins, determinados interesses legítimos. A ação dos fornecedores, a publicidade, a oferta, o contrato firmado criam no consumidor expectativas, também, legítimas de poder alcançar estes efeitos contratuais. No sistema tradicional, seus intentos poderiam vir a ser frustrados, pois o fornecedor, elaborando unilateralmente o contrato, o redigia da forma mais benéfica a ele, afastando todas as garantias e direitos contratuais que a lei supletiva civil permitisse (direitos disponíveis). No sistema do CDC, leis imperativas irão proteger a confiança que o consumidor depositou no vínculo contratual, mais especificamente na prestação contratual, na sua adequação ao fim que razoavelmente dela se espera, e irão proteger também a confiança que o consumidor deposita na segurança do produto ou serviço colocado no mercado.

Interessante notar que o mandamento de proteção da confiança (Vertrauensgebot) está intimamente ligado pode-se mesmo afirmar ser esta uma consequência ética - ao anonimato das novas relações sociais. Como as relações contratuais e pré-contratuais, a produção, a comercialização são massificadas e multiplicadas, sem que se possam claramente identificar os beneficiados (consumidores e usuários), foi necessário criar um novo paradigma. Um novo paradigma mais objetivo do que a subjetiva vontade, boa ou má-fé do fornecedor in concreto, mas sim um standard de qualidade e segurança que pode ser esperado por todos, contratantes, usuários atuais e futuros (expectativas legítimas).

Note-se que a ciência do direito, para proteger convenientemente a confiança despertada pela atuação dos fornecedores no mercado, terá de superar a summa divisio entre a responsabilidade contratual e a extracontratual, e o fará revigorando a figura dos deveres anexos (Nebenpflichten). Estes são deveres de conduta, deveres de boa-fé presentes nas relações sociais mesmo antes da conclusão dos contratos, presentes mesmo depois de exauridas as prestações principais ou em caso de contratos nulos ou existentes. Em verdade, os deveres anexos de cuidado, de informação, de segurança e de cooperação estão presentes em todas as relações, mesmo as extracontratuais, pois são deveres de conduta humana (Verkehrspflichten), só indiretamente (ou eventualmente) dirigidos à prestação contratual." (MARQUES, Claudia Lima. Contratos no Código de Defesa do Consumidor: o novo regime das relações contratuais. 5. ed. São Paulo: Ed. Revista dos Tribunais, 2005. p. 1142-1143).
} 
De fato, a responsabilidade pelo fato do produto ou do serviço decorre da ocorrência de um vício de qualidade, um defeito capaz de frustrar a legítima expectativa do consumidor quanto à sua utilização e fruição. ${ }^{131}$ É importante mencionar que existe tendência doutrinária que defende a dicotomia entre vício de qualidade e defeito, o que, a nosso ver, não se aplica, pois são expressões recíprocas. Tanto o defeito quanto o vício de qualidade são identificados por não corresponderem à legítima expectativa do consumidor.

Zelmo Denari assevera que se entende por defeito ou vício de qualidade a qualificação de desvalor atribuída a um produto ou serviço por não corresponder à legítima expectativa do consumidor, quanto à sua utilização ou fruição (falta de adequação), bem como por adicionar risco à integridade física (periculosidade) ou patrimonial (insegurança) do consumidor ou de terceiro. ${ }^{132}$

O fato exclusivo imputável ao consumidor quebra o nexo de causalidade, isso porque a ocorrência do dano, embora tenha tido participação de um produto ou serviço teve como causa exclusiva a conduta culposa da própria vítima.

A supracitada autora menciona que seria o caso da aceitação dos efeitos colaterais de remédios, da ingestão dos polêmicos alimentos transgênicos e dos males que podem advir do uso excessivo do celular ou do computador. ${ }^{133}$

\footnotetext{
${ }^{131}$ Marcelo Junqueira Calixto observa que: "Neste tema, o que pode ser inicialmente destacado é que a responsabilidade civil está fundada no pressuposto da existência de um defeito, sendo este visto como violação de uma legítima expectativa de segurança, a qual pode ser afirmada segundo alguns critérios exemplificativamente previstos na lei (CDC, art. $12, \S 1^{\circ}$ e art. $\left.14, \S 1^{\circ}\right)$.

Não se trata, propriamente, de uma responsabilidade pelo risco do empreendimento ou pelo risco do negócio, mas sim de uma responsabilidade por produtos ou serviços defeituosos. A afirmação deste caráter defeituosos não toma por padrão a vítima do dano, mas a legítima expectativa de segurança da sociedade de consumo, o que não torna a noção menos controversa.

Salienta-se, contudo, que o CDC brasileiro, ao contrário da norma europeia que lhe serviu de inspiração na matéria relativa ao fato do produto, adotou uma presunção relativa da existência de defeito, uma vez ocorrido o dano, o que decorre do fato deste diploma impor ao fornecedor de produtos, e também ao

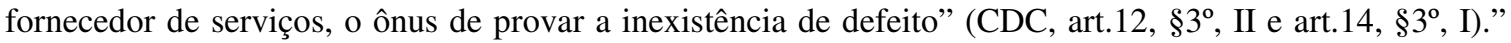
(CALIXTO, Marcelo Junqueira. A culpa na responsabilidade civil. Rio de Janeiro: Renovar, 2008. p. $192-$ 193).

${ }^{132}$ DENARI, Zelmo et al. Código Brasileiro de Defesa do Consumidor comentado pelos autores do anteprojeto. 8. ed. Rio de Janeiro: Forense Universitária, 2004. p. 174.

${ }^{133}$ MARQUES, Claudia Lima. op. cit., p. 16.
} 


\subsubsection{Do defeito}

A responsabilidade por fato do produto trata dos danos decorrentes de defeitos, nos termos do artigo 12 do CDC, enquanto os danos resultantes de vícios são matéria de responsabilidade pelo vício de produtos. ${ }^{134}$

O conceito de defeito funda-se na falta de segurança do produto, portanto, produto é defeituoso por ser inseguro, contudo nem todo produto inseguro é defeituoso. De fato, o CDC consagrou um conceito unitário de defeito no que se refere à responsabilidade por acidentes de consumo, qual seja, a falta de conformidade do produto em relação à legítima expectativa de segurança da sociedade.

Fábio Ulhoa Coelho observa que:

"Defeito é a impropriedade, algo que não deveria ser o que é. Distinguese do perigo na medida em que neste os produtos ou serviços são exatamente o que deveriam ser, embora as informações sobre os seus riscos não se mostrem insuficientes ou adequadas à capacitação do consumidor quanto ao seu consumo seguro. No fornecimento defeituoso

\footnotetext{
${ }^{134}$ Cabe transcrever julgado de Relatoria da Min. Nancy Andrighi: CONSUMIDOR. RESPONSABILIDADE PELO Fato ou Vício do Produto. Distinção. Direito de Reclamar. Prazos. Vício de Adequação. Prazo Decadencial. Defeito de Segurança. Prazo prescricional. Garantia legal e Prazo de

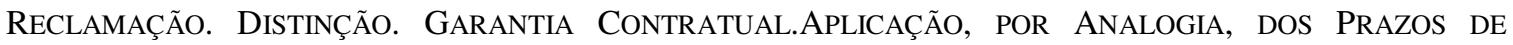
RECLAMAÇÃO ATINENTES À GARANTIA LEGAL.

- No sistema do CDC, a responsabilidade pela qualidade biparte-se na exigência de adequação e segurança, segundo o que razoavelmente se pode esperar dos produtos e serviços. Nesse contexto, fixa, de um lado, a responsabilidade pelo fato do produto ou do serviço, que compreende os defeitos de segurança; e de outro, a responsabilidade por vício do produto ou do serviço, que abrange os vícios por inadequação.

- Observada a classificação utilizada pelo CDC, um produto ou serviço apresentará vício de adequação sempre que não corresponder à legítima expectativa do consumidor quanto à sua utilização ou fruição, ou seja, quando a desconformidade do produto ou do serviço comprometer a sua prestabilidade. Outrossim, um produto ou serviço apresentará defeito de segurança quando, além de não corresponder à expectativa do consumidor, sua utilização ou fruição for capaz de adicionar riscos à sua incolumidade ou de terceiros.

- O CDC apresenta duas regras distintas para regular o direito de reclamar, conforme se trate de vício de adequação ou defeito de segurança. Na primeira hipótese, os prazos para reclamação são decadenciais, nos termos do art.26 do CDC, sendo de 30 (trinta) dias para produto ou serviço não durável e de 90 (noventa) dias para produto ou serviço durável. A pretensão à reparação pelos danos causados por fato do produto ou serviço vem regulada no art. 27 do CDC, prescrevendo em 05 (cinco) anos.

- A garantia legal é obrigatória, dela não podendo se esquivar o fornecedor. Paralelamente a ela, porém, pode o fornecedor oferecer uma garantia contratual, alargando o prazo ou o alcance da garantia legal.

- A lei não fixa expressamente um prazo de garantia legal. O que há é prazo para reclamar contra o descumprimento dessa garantia, o qual, em se tratando de vício de adequação, está previsto no art. 26 do CDC, sendo de 90 (noventa) ou 30 (trinta) dias, conforme seja produto ou serviço durável ou não.

- Diferentemente do que ocorre com a garantia legal contra vícios de adequação, cujos prazos de reclamação estão contidos no art. 26 do $\mathrm{CDC}<$ a lei não estabelece prazo de reclamação para a garantia contratual. Nessas condições, uma interpretação teleológica e sistemática do CDC permite integrar analogicamente a regra relativa à garantia contratual, estendendo-lhe os prazos de reclamação atinentes à garantia legal, ou seja, a partir do término da garantia contratual, o consumidor terá 30 (bens não duráveis) ou 90 (bens duráveis) dias para reclamar por vícios de adequação surgidos no decorrer do período desta garantia.

Recurso especial conhecido e provido. (REsp 967623/RJ, Terceira Turma, 16/04/2009).
} 
haverá sempre disparidade, dessintonia, desacordo entre um fator ideal e outro real. No defeito de concepção, o descompasso estabelece-se entre o projeto empresarial que poderia ser elaborado com o aproveitamento de todos os recursos oferecidos pela ciência e tecnologia para a produção do bem ou serviço em questão e o projeto empresarial efetivamente desenvolvido. No defeito de execução, o descompasso verifica-se entre a fabricação ou conservação do produto ou prestação do serviço e o respectivo projeto empresarial. No defeito de comercialização, por fim, entre o padrão de informações adequadas e suficientes sobre a utilização do produto e o conjunto de dados a esse respeito efetivamente transmitido aos consumidores." 135

O CDC agrupou todos os defeitos no mesmo dispositivo; tratando-os de forma unitária e genérica no artigo 12: de concepção, de fabricação e de informação.

Há o defeito de concepção quando resultar tanto de erro no projeto tecnológico do produto, quanto da inadequação do material escolhido, quanto, ainda, de opção por componente que se revele prejudicial à saúde do consumidor.

Da mesma forma, há defeito de fabricação, quando houver falhas no processo de fabricação, construção, montagem, manipulação, utilização das fórmulas, apresentação ou acondicionamento do produto. Em geral, esses defeitos se identificam pela comparação com o produto padrão ou com outros exemplares da linha de produção. ${ }^{136}$

E, por último, o defeito de informação consiste basicamente na instrução insuficiente ou inadequada, sobre o produto, sobre sua utilização e as consequências dessa utilização. Esse tipo de defeito configura-se quando o fabricante coloca o produto em circulação sem ilustrar o modo de emprego e os perigos que o uso do produto pode acarretar para o consumidor.

De fato, quando a confiança ou a boa-fé é "quebrada" diante da existência de um defeito impõe-se para o CDC a responsabilização do fornecedor. O defeito é o artifício utilizado pelo legislador consumerista para que a responsabilidade do fornecedor não se tornasse integral, ainda que haja dano e o nexo causal; sem o defeito, porém, não haverá indenização.

\footnotetext{
${ }^{135}$ COELHO, Fabio Ulhoa. O empresário e os direitos do consumidor: o cálculo empresarial na interpretação do Código de Defesa do Consumidor. São Paulo: Saraiva, 1994. p. 90.

${ }^{136}$ SILVA, João Calvão da. op. cit., p. 658.
} 
Com efeito, o fundamento da responsabilidade civil objetiva no âmbito do consumidor não é a do risco criado, em contrapartida o defeito do produto justifica a responsabilidade civil. ${ }^{137}$

Não é qualquer dano causado pelo produto que deverá ser ressarcido, sob pena de tornar o fornecedor segurador do próprio produto; exige-se um dano qualificado, diretamente causado por defeito.

Ressalte-se que para o direito do consumidor não basta apenas o dano. Em suma, o fato do produto ocorre quando o defeito ocorrido não satisfaz as legítimas expectativas de segurança do consumidor.

Na Diretiva 85/374 da CEE em que a regra é a excludente de responsabilidade, no caso do risco do desenvolvimento, não há dúvidas com relação ao defeito, apenas ele era desconhecido na época em que foi colocado em circulação.

A Diretiva supracitada considera um produto defeituoso, em seu artigo $6^{\circ}$ :

"Um produto é defeituoso quando não oferece a segurança a que uma pessoa tem legitimamente direito, tendo em conta todas as circunstâncias, inclusive:
a) a apresentação do produto;
b) o uso que razoavelmente se pode esperar do produto;
c) o momento em que o produto é colocado em circulação."

Indaga-se se nos riscos do desenvolvimento, para o direito brasileiro, o defeito estaria presente, já que não foi possível detectar pelo mais alto grau de tecnologia e ciência. De certo os riscos fazem parte de qualquer sociedade que busca o progresso e a superação de limites, por isso não se pode bani-los integralmente, o que pode ser feito é diluir os seus efeitos. Abordaremos melhor a questão no capítulo seguinte.

\footnotetext{
${ }^{137}$ Claudia Lima Marques com acuidade observa: O dever legal instituído pelo CDC seria, então, de só introduzir no mercado produtos livres de defeitos (art.12, §3º I e II). Por conseguinte, não basta a atividade de risco de introduzir o produto no mercado e lucrar com isto (cujus commodum, ejus periculum), porque também os comerciantes-finais o fazem e não são responsáveis principais no sistema do CDC (art.12, caput). Assim, na sistemática do Código, todos os fornecedores que ajudam a introduzir o produto no mercado podem ser potencialmente responsabilizados ( é o caso do comerciante na hipótese do art.13), mas a figura européia do defeito concentrou a imputação em alguns fornecedores, não com base no simples risco criado por sua atividade (ou imputaria a todos a responsabilidade, como no sistema norte-americano), mas com base em uma valoração legal específica. (MARQUES, Claudia Lima. op. cit., p. 1039).
} 


\subsection{Do nexo de Causalidade}

É o requisito mais difícil de ser identificado em matéria de responsabilidade. Etimologicamente a palavra nexo vem do latim nexus, que significa vincular, unir. ${ }^{138}$

É válido transcrever as palavras de Adriano De Cupis:

"Nexo de causalidade é o vínculo que se interpõe entre dois fenômenos distintos, assumindo um a posição de efeito em relação ao outro: quando um fenômeno existe em razão da existência de um outro fenômeno, aquele que se diz 'causado' por esse, a indicar que uma relação de causalidade se estabelece entre ambos. Mais precisamente, relação de causalidade é o nexo etiológico material (ou seja, objetivo e externo) que liga um fenômeno a outro; no que concerne ao dano, esse se constitui no fator da sua imputação matrial ao sujeito humano." 139

Sem a comprovação do nexo de causalidade, seja a responsabilidade subjetiva ou seja objetiva, não há ressarcimento. Isso significa dizer que o agente do dano só responderá pelo dano que efetivamente causou. Persiste para o consumidor a obrigação de comprovar a existência de produto viciado, o dano e o nexo de causalidade entre o dano e a utilização do produto.

Indiscutivelmente, o nexo causal é a primeira questão e a sua comprovação exige absoluta segurança entre o vínculo de determinado comportamento e o evento danoso.

Um produto será considerado defeituoso quando não corresponder à legítima expectativa do consumidor a respeito de sua utilização, vale dizer, quando ocorrer a desconformidade do produto ou serviço com a prestabilidade. Para que o fornecedor tenha o dever de indenizar deve existir, obrigatoriamente, um liame causal entre o defeito existente no produto ou serviço e o dano sofrido pela vítima, a grande dificuldade consiste no fato de que em inúmeras vezes não é possível afirmar, com precisão, se há ou não nexo causal entre o produto supostamente defeituoso e o dano sofrido pela vítima.

\footnotetext{
${ }^{138}$ João Calvão da Silva observa: "Vale isto dizer que nem todos e quaisquer danos sobrevindos ao defeito do produto são incluídos na responsabilidade do produtor, são-no tão-somente os causados ou provocados pelo defeito. Daí que o nexo de causalidade seja requisito ou pressuposto da responsabilidade e funcione ainda como medida da obrigação de indenizar." (SILVA, João Calvão da. op. cit., p. 15).

${ }^{139}$ DE CUPIS, Adriano. Il danno teoria generale della responsabilità civile. 2. ed. Milano: Giuffrè, 1996. v. 1, p. 215.
} 
É o liame causal entre o comportamento e o evento danoso, aspecto primordial para o instituto em questão. ${ }^{140}$

Certo é que existem inúmeras teorias sobre o assunto, teoria da equivalência das condições, causalidade adequada, da causa direta e imediata, entre outras.

A da equivalência das condições, atribuída ao alemão Maximiliano Von Buri, considera todas as condições a fim de identificar a causa do dano, sem dúvida, não pode ser aplicada, em virtude da amplitude. Todos os fatos teriam provocado o dano e nessa medida teriam relevância causal. O jurista alemão partia do pressuposto de que todas as condições eram equivalentes. Para ele todas as condições causais teriam importância para a produção do resultado.

\footnotetext{
${ }^{140} \mathrm{O}$ dano é, sem dúvida, indispensável para a responsabilização do fornecedor, exemplo é o seguinte julgado: "Ementa: Ação de indenização - Danos morais e materiais - Relação de consumo - Art.12 do CDC - Fornecedor - Culpa objetiva - Necessidade de comprovação do vício do produto e do nexo de causalidade entre o dano suportado e o vício apontado - Ausência de provas - Parte sob o manto da gratuidade judiciária - Condenação em sucumbência - Suspensão - Literalidade do art.12 da Lei 1.060/50. Tratando-se de relação entre consumidor e fornecedor, aplica-se o disposto no art.12 do CDC, pelo qual resta dispensada a prova acerca do elemento subjetivo, qual seja a culpa do autor da lesão. A par da inversão probatória determinada, e mesmo diante da aplicação da teoria da responsabilidade objetiva, persiste para o consumidor a obrigação de provar a existência dos danos, bem como o nexo causal entre estes e o alegado vício do produto, porquanto se trata de fato constitutivo de seus direitos. Comprovando-se tão-somente o dano, é incabível a responsabilização do fornecedor, pela ausência dos demais requisitos. Se a parte litiga sob o pálio da assistência judiciária, tal circunstância não implica isenção de sucumbência, mas, sim, a suspensão de sua exigibilidade, na forma do art.12 da Lei 1.060/50." (ApCív. 1.064.06.000127-7/001 - Comarca de Santo Antônio do Monte - Apelante : Jovita Alves dos Santos - Apelada: Oft Vision Indústria e Comércio Ltda. Relator: Exmo. Sr. Des. Osmando Almeida, por unanimidade foi negado provimento ao recurso, 11 de dezembro de 2007).

Outros julgados no mesmo sentido: Civil e processual civil - Ação indenizatória - Agravo retido - Dano moral - Valor da causa - Responsabilidade civil - Acidente de consumo - Defeito do produto - Existência não comprovada - Conduta ilícita do fabricante indemonstrada - ausência de comprovação do nexo etiológico entre o dano e o alegado defeito do produto - inteligência do art. 258 do CDC. O valor da causa deve ser correlato ao valor do pedido, ou, aproximadamente, ao benefício patrimonial perseguido, pois, para fins de fixação do valor da causa, deve ser retratado, justamente, o valor que corresponde à expectativa econômica do autor em relação ao seu pedido, ainda que este não tenha conteúdo econômico imediato, consoante interpretação do constante do Digesto Processual. Em que pese a adoção da responsabilidade objetiva pelo Código de Defesa do Consumidor, tem-se que o $\$ 3^{\circ}$ do mencionado dispositivo legal não dispensa o nexo etiológico entre a atividade do fabricante, produtor, construtor ou importador e o fato danoso bem como o defeito do produto, não sendo suficiente, para se impor a obrigação de reparar os danos decorrentes de acidente com produtos alimentícios, apenas a existência do dano, porque o dever de indenizar pressupõe que seja evidenciado o nexo de causalidade entre o dano e a conduta ilícita do fornecedor. (AP. 321.183-0, 3 $3^{\text {a }}$ Câm. Civ, do extinto TAMGm rel. Juiz Dorival Guimarães Pereira, j.18.04.2001).

Reparação de danos / Prestação de serviços de troca de óleo / Código de Defesa do Consumidor / Responsabilidade objetiva do fornecedor / Ausência de nexo de causalidade - Manutenção da sentença. Nos contratos de prestação de serviços, vigora a teoria da responsabilidade objetiva aliada à teoria do risco do negócio, bastando ao consumidor provar o defeito do serviço, o dano sofrido e o nexo de causalidade entre este e a prestação do fato para se impor a responsabilização do prestador devidamente identificado. Ausente um dos requisitos, qual seja, o nexo de causalidade, é de se manter a improcedência da ação de reparação de danos. Apelação não provida. (AP. 362.726-1, 2a Câm, Civ. do extinto TAMG, rel. Juiz Edgard Penna Amorim, j. 12.11.2002).
} 
Adriano De Cupis, ao explicar a teoria, elucida que todas as condições são equivalentes entre si e para o direito não se elege uma determinada para considerá-la causa do efeito danoso. ${ }^{141}$

Foi considerada abrangente demais por muitos, sem quaisquer abrandamentos e com má percepção fática, portanto, insatisfatória, pois a ocorrência de qualquer outra circunstância não seria relevante para o efeito de excluir o nexo causal. ${ }^{142}$

Por outro lado, a teoria da causalidade adequada ou teoria subjetiva da causalidade invoca os antecedentes que são próprios para produzi-los, o que levaria ao dano; ou seja, dentre vários se eliminam os que seriam indiferentes a causar o dano e se escolhe o que de fato seria adequado a causar o dano. ${ }^{143}$

É necessário averiguar se a ação ou a omissão do agente era capaz de provocar normalmente o dano; retroage-se na data do fato para verificar se aquela era suficiente para causar o prejuízo.

A teoria da causalidade adequada propõe a distinção entre causas e consequências; a causa além de ser necessária será adequada à produção do dano. Será

\footnotetext{
${ }^{141}$ DE CUPIS, Adriano. op. cit., p 193-194.

${ }^{142}$ Gisela Sampaio da Cruz ilustra que: "Assim como no Direito Penal é preciso diferenciar o autor do coautor e do cúmplice, forçoso é distinguir, na responsabilidade civil, os fatores principais e imediatos do prejuízo dos fatores secundários. Segundo o mencionado autor, quando, por exemplo, um indivíduo é empurrado e cai sobre um muro protegido com cacos de vidro, pelos quais fica gravemente ferido, "não pode dizer-se que o dono do muro foi causa do prejuízo e que o caso fortuito de haver aqueles vidros é equivalente ao empurrão". Nelson Hungria, por sua vez, afirma que, de acordo com esta teoria, o fabricante da arma com a qual o dano se perpetrou responderia pelo evento danoso. E, em nota de rodapé, evoca curiosa passagem de Binding, em que este assinala com fina ironia que, a se acolher a Teoria da Equivalência das Condições em toda a sua extensão, talvez tivesse de responsabilizar também, como partícipe do adultério, o próprio marceneiro que fabricou o leito onde se deitou o casal amoroso."

E conclui: "A Teoria da Equivalência dos Antecedentes Causais mereceu, portanto, as críticas da doutrina, em razão de seus transbordamentos inevitáveis, ensejando regressões infinitas a causas anteriores, que quase sempre levam a decisões injustas." (CRUZ, Gisela Sampaio da. O problema do nexo causal na responsabilidade civil. Rio de Janeiro: Renovar, 2005. p. 44-45).

${ }^{143}$ Julgado que trata sobre a teoria: Trata-se de aplicação concreta da teoria da causalidade adequada, que orienta as normas sobre o nexo causal na responsabilidade civil no direito brasileiro.

A teoria da causalidade adequada, que é a prevalente no âmbito da responsabilidade civil (diferentemente da responsabilidade penal onde tem prevalência a teoria da equivalência dos antecedentes por força do art.13 do Código Penal), restringe o conceito de causa, estabelecendo como tal apenas a condição que, formulado um juízo abstrato, se apresenta verificação concreta de um determinado processo causal, deve-se formular um juízo de probabilidade com cada uma das múltiplas possíveis causas, de acordo com a experiência comum, em um plano abstrato. Se após a análise de certo fato for possível concluir que era provável a ocorrência do evento, deve-se reconhecer a relação de causa e efeito entre eles.

A causa é aquela condição que demonstrar melhor aptidão ou idoneidade para causação de um resultado lesivo. Nesta perspectiva, causa adequada é aquela condição que demonstrar melhor aptidão ou idoneidade para causação de um resultado lesivo. Nesta perspectiva, causa adequada é aquela que apresenta como consequiência normal e efeito provável a ocorrência de outro fato. (Apelação Cível no 70003579968, 9ª Câmara do TJ/RS, j.14/08/02, rel. Des. Paulo de Tarso Vieira Sanseverino).
} 
causa adequada se existir sempre, em qualquer circunstância. Se somente uma circunstância acidental explica essa causalidade, diz-se que a causa não era adequada.

O problema da teoria da causalidade adequada é sua imprecisão, pois em muitas vezes é impossível definir qual concausa foi determinante para produzir o dano.

E, por fim, a da causa direta e imediata, também denominada de teoria da interrupção do nexo causal. Vale lembrar que o Código Civil de 2002 a adotou expressamente no artigo 403, muito embora mal localizada, já que está prevista na responsabilidade contratual, quando, na verdade, deveria abranger a responsabilidade extracontratual. $^{144}$

Indiscutivelmente, não é pacífico o entendimento, no que concerne à teoria adotada pelo nosso ordenamento jurídico brasileiro.

Na vigência do Código Civil de 1916, a doutrina e a jurisprudência firmaram entendimento no sentido de adotar a teoria da causa adequada ou causa eficiente, direta ou imediata, com base na parte final do artigo 1.060, entretanto, não disciplinava exatamente sobre nexo causal, mas sobre perdas e danos. Outrossim, o artigo 403 do Código de 2002 apenas transcreveu o que havia sido disciplinado no supracitado artigo do Código revogado.

Esse artigo é alvo de inúmeras críticas em razão de sua má localização no Diploma Civil, pois pode ser aplicado tanto à responsabilidade contratual quanto à extracontratual, por isso não poderia constar no título referente ao inadimplemento das obrigações, mas sim nos capítulos referentes à responsabilidade civil. Além disso, a expressão ‘direto e imediato' suscita uma série de dúvidas em relação ao ressarcimento dos danos indiretos.

A maior parte da doutrina nacional adota a teoria do nexo causal direto e imediato com a causalidade necessária. Enquanto a doutrina minoritária acolhe a teoria da causalidade adequada. A preferência da maioria pela teoria da causalidade necessária seria em razão da reparação dos danos indiretos e estabelecer limites no rompimento do nexo causal.

\footnotetext{
${ }^{144}$ Agostinho Alvim preleciona: “O raciocínio em que ela se apóia é o seguinte : apreciando certo dano, temos que concluir que o fato que o originou era capaz de lhe dar causa. Mas, pergunta-se, tal relação de causa e efeito existe sempre, em casos dessa natureza, ou existiu nesse caso por força de circunstâncias especiais ? Se existir sempre, diz-se que a causa era adequada a produzir o efeito; se somente uma circunstância acidental explica essa causalidade, diz-se que a causa não era adequada." (ALVIM, Agostinho. Da inexecução das obrigações e suas conseqüências. São Paulo: Saraiva, 1965. p. 329).
} 
De fato, os danos advindos do risco do desenvolvimento não são diretos e imediatos; são, na verdade, conhecidos posteriormente com a utilização do produto.

Agostinho Alvim ensina que ' a expressão direto e imediato significa o nexo causal necessário’. O dano deve ser conseqüência necessária da inexecução da obrigação. Nessa teoria identifica-se a subteoria da causalidade necessária, sendo o dever de reparar configurado quando o evento danoso for efeito de determinada causa, sendo motivo para interromper se determinado resultado não fosse consequência dos fatos. ${ }^{145}$

A teoria da causalidade necessária proposta por Agostinho Alvim afirma que não importa se a causa é próxima ou remota ao dano, mas deve, obrigatoriamente, atrelar-se diretamente a ele, como sua causa exclusiva. Portanto, será indenizável todo o dano que se filia a uma causa, mesmo que remota, desde que seja necessária, por não existir outra que explique a ocorrência do dano.

Nos ordenamentos jurídicos que acolhem essa teoria o nexo causal será interrompido quando a própria "vítima" ou terceiro é o causador do dano, mas também quando a causa próxima é um fato natural.

A era da massificação da produção e do consumo trouxe o alargamento da teoria da responsabilidade civil, adotando-se a teoria do risco a fim de proteger a vítima; o problema de causalidade impede que essa teoria se torne integral, já que não foi adotada pelo CDC.

Georges Ripert define a teoria do risco como:

"todo o prejuízo deve ser atribuído ao seu autor e reparado por aquele que o causou, porque todo o problema de responsabilidade civil resolvese em um problema de causalidade, ou ainda: qualquer fato do homem obriga aquele que causou um prejuízo a outrem repará-lo." 146

A teoria do risco tem por principal pressuposto o nexo causal, o que faz concluir que desaparecerá a responsabilidade com a caracterização de uma excludente. Dessa

\footnotetext{
${ }^{145}$ Ministro Nilson Naves observa, em seu voto: “ (...) não restou comprovado, nestes autos, tratar-se o vidro temperado, de produto defeituoso, e, reparem bem, também não acabou demonstrado tratar-se de vidro laminado, de produto melhor, isto é, de produto que ofereça maior segurança aos ocupantes de veículos ('em conseqüência de impacto e diminuir a possibilidade de acidente devido à perda de visão através de pára-brisa'). Por isso, nessa linha, torna-se difícil, senão impossível, o estabelecimento da causalidade; a propósito, disse, e corretamente, o acórdão recorrido : a conduta do fabricante do veículo está muito longe de uma relação de causalidade mercê da qual, mesmo no campo da responsabilidade objetiva (não é o caso) se justificasse o dever de reparação.” (STJ, REsp 2821/RJ, 3ª., Rel.Min. Gueiros Leite, j.16.10.1990).

${ }^{146}$ RIPERT, Georges. A regra moral nas obrigações civis. Campinas: Bookseller, 2000. p. 213.
} 
forma, devem, impreterivelmente, estar presentes todos os requisitos autorizadores da obrigação de indenizar, quais sejam, ação ou omissão, nexo de causalidade e dano.

\subsubsection{Da flexibilização do nexo de causalidade}

Indaga-se se é possível flexibilizar o principal requisito da responsabilidade civil objetiva, o nexo de causalidade, diante da sociedade atual, tão imersa em sua complexidade de novos produtos diariamente inseridos no mercado. Há que se ter em mente que o nexo de causalidade nunca poderá ser presumido.

Caio Mario da Silva Pereira definiu o nexo causal como o 'mais delicado dos elementos da responsabilidade civil e o mais difícil de ser determinado'. ${ }^{147}$

Com efeito, a única maneira de se excluir a responsabilidade é por meio da interrupção do nexo causal, ainda assim, o Código de Defesa do Consumidor não traz regra expressa específica sobre como se deve considerá-lo.

Anderson Schreiber adverte que muitos casos levados à apreciação judicial revelam que nenhuma das teorias da causalidade soluciona de modo satisfatório a questão, pois a própria noção de certeza e segurança encontra-se em mutação. ${ }^{148}$

E adiante acrescenta que a doutrina jurídica ignora as relações de causa e efeito do universo científico. Há que se reconhecer o caráter móvel da ciência.

\footnotetext{
${ }^{147}$ PEREIRA, Caio Mario da Silva. Responsabilidade civil. Rio de Janeiro: Forense, 1999. p. 76.

${ }^{148}$ Anderson Schreiber adverte que: "Os manuais procuram dar resposta, por exemplo, ao sem-número de situações em que o conhecimento científico hodierno impede afirmar, com precisão, se há (ou se não há!) nexo causal entre certo produto e o dano sofrido pela vítima, como se vê nos casos de uso de medicamentos defeituosos ou de poluição ambiental."

Em um cenário assim tão versátil, a própria noção de causalidade escapa a um rigorismo lógico incompatível com a velocidade estonteante das descobertas científicas. No campo jurídico, as cortes se mostram cada vez menos dispostas a enxergar a impossibilidade de demonstração técnica da causalidade como um obstáculo intransponível à reparação dos danos. Em uma silenciosa revolução jurisprudencial, a análise do nexo causal abandona a esfera do tecnicismo estrito para vir sofrer a influência de elementos valorativos atinentes à própria distribuição dos custos da vida social.

Essa flexibilização, ainda inicial, do nexo de causalidade se exprime por caminhos variados. Ora, assume a forma nociva de decisões intuitivas, descomprometidas com qualquer fundamentação controlável, que se limitam a proceder ao que já foi chamado de "presunções clandestinas de causalidade", desprovidas de qualquer justificação científica. Em outras ocasiões, todavia, o que se vê é um esforço valoroso dos tribunais que as teorias tradicionais não conseguem dar resposta. A parcela menos estática da doutrina procura fornecer bases científicas para essa flexibilização da causalidade, de modo a permitir uma visão que, a um só tempo, exprima uma concepção menos tecnicista do nexo causal, sem, contudo, representar uma anarquização sentimental do conceito, ainda imprescindível à configuração do dever de indenizar." (SCHREIBER, Anderson. op. cit., p 33-34).
} 
Em suas palavras, o autor ressalva:

"Essa flexibilização, ainda inicial, do nexo de causalidade se exprime por caminhos variados. Ora, assume a forma nociva de decisões intuitivas, descomprometidas com qualquer fundamentação controlável, que se limitam a proceder ao que já foi chamado de "presunções clandestinas de causalidade", desprovidas de qualquer justificação científica. Em outras ocasiões, todavia, o que se vê é um esforço valoroso dos tribunais para adequar a noção de causalidade à realidade do seu tempo, enfrentando situações a que as teorias tradicionais não conseguem dar resposta. A parcela menos estática da doutrina procura fornecer bases científicas para essa flexibilização da causalidade, de modo a permitir uma visão que, a um só tempo, exprima uma concepção menos tecnicista do nexo causal, sem, contudo, representar uma anarquização sentimental do conceito, ainda imprescindível à configuração do dever de indenizar." 149

A regra geral, sem dúvida, é que o agente deve responder por todo o dano que causou, ou se apenas pelo dano que efetivamente deu causa, caso contrário estar-se-á responsabilizando o próprio marceneiro que fabricou o leito no qual se deitou o casal amoroso como partícipe do adultério ${ }^{150}$. Ainda que atualmente seja manifesto o aumento do sistema de seguros e garantias e algumas previsões legais de solidariedade, nos termos do artigo 12 do Código de Defesa do Consumidor.

Gisela Sampaio da Cruz admite que há vezes que o agente, muito embora tenha participado em determinado evento danoso e à primeira vista parece ser o causador do dano, nesses casos, o agente não pode ser obrigado a indenizar à vítima, porque é apenas o 'responsável aparente' pelo dano. ${ }^{151}$

E a autora cita o exemplo, em suas palavras:

"Caio atropela Tício ( $1^{\mathrm{a}}$ série causal), mas este vem a morrer no hospital, (i) porque se suicida ( $2^{\mathrm{a}}$ série causal); (ii) em decorrência de um erro médico ( $2^{\mathrm{a}}$ série causal); (iii) ou de um incêndio ocasionado por um raio que atinge o hospital ( $2^{\mathrm{a}}$ série causal). Nestes exemplos, a $2^{\mathrm{a}}$ série causal

\footnotetext{
${ }^{149}$ Adiante observa que: A doutrina jurídica, avessa à interdisciplinariedade, ignora, quase sempre, o impacto de estatísticas, projeções e outros dados atinentes às relações de causa e efeito no universo científico. A própria noção de certeza, contudo, encontra-se em mutação. Em passagem já célebre de seu Runaway World, Anthony Giddens enfatiza como característica do mundo globalizado o reconhecimento do caráter móvel da ciência. Antes tida como fator de certeza em face das incertezas da irracionalidade, a ciência teria, hoje, passado a ser causa de mais insegurança, por seu extremo dinamismo. 'Consider redwine' exemplifica Giddens - "Como outras bebidas alcoólicas, o vinho tinto em quantidade moderada diminuía o risco de doenças cardíacas. Em seguida, descobriu-se que qualquer forma de álcool serve, mas que o efeito apenas se verifica em pessoas de idade superior a 40 anos. Quem sabe o que as próximas pesquisas irão revelar?

${ }^{150}$ Citação de Binding no livro de SILVA, Wilson Melo da. Responsabilidade sem culpa. São Paulo: Saraiva, 1974. p. 117.

${ }^{151}$ CRUZ, Gisela Sampaio da. op. cit., p. 157.
} 
que interrompeu a $1^{a}$ série foi, respectivamente, um fato da própria vítima, um fato de terceiro e um caso fortuito ou de força maior. A $2^{\mathrm{a}}$ série é a causa real do dano (morte); ao passo que a $1^{\mathrm{a}}$ série se torna causa virtual ou hipotética do dano (isto é, causa hipotética da morte, mas causa real das lesões). Questiona-se aqui se o agente da causa virtual (Caio) deve responder pela morte de Tício, o que equivale a perguntar se a causa virtual tem relevância positiva. A resposta é negativa. Se ocorreu de fato interrupção do nexo causal, Caio apenas deve responder pelas lesões que Tício sofreu em razão do atropelamento, mas não pela morte." 152

De fato, semelhante ao que ocorreu com a prova da culpa, a prova do nexo causal parece tendente a sofrer a flexibilização, no seu papel de filtro de responsabilidade civil. ${ }^{153}$ Entretanto, ainda que a tendência seja a o abrandamento na sua prova, é o requisito,

${ }^{152}$ CRUZ, Gisela Sampaio da. op. cit., p. 158.

A autora cita um julgado do STJ que ilustra bem a problemática da jurisprudência brasileira ao examinar os pressupostos da interrupção do nexo causal: O erro do médico no tratamento das lesões sofridas em acidente de trânsito provocado culposamente pelo preposto da ré está no desdobramento causal do acidente; pelo resultado mais grave responde o causador do dano, ressalvado à ré o direito de pleitear eventual ressarcimento junto a quem concorreu com a sua imperícia. Recurso não conhecido. (STJ, $4^{\mathrm{a}} \mathrm{T}$, REsp 326.971/AL, Rel. Min. Rui Rosado de Aguiar, j. 11.06.2002, v.u.) No caso concreto, o acidente de trânsito fez com que a vítima tivesse de se submeter a uma cirurgia, na qual, por flagrante erro médico, foi esquecido em sua traquéia um corpo estranho (compressa de gaze). O erro médico, por sua vez, levou a vítima a uma segunda operação - desta vez de broncofibroscopia. É evidente que, nessa hipótese, ocorreu interrupção do nexo causal, razão pela qual o agente responsável pelo acidente não deveria ter sido obrigado a arcar com os custos da segunda cirurgia. Os danos decorrentes do erro médico jamais poderiam ter sido considerados consequencia direta e imediata (necessária) do acidente de trânsito. Isto porque a cirurgia de broncofiscopia não decorre, necessariamente, do acidente de trânsito, assim como também não é consequência necessária da primeira cirurgia. Resulta, isto sim, do erro médico - se o médico não tivesse esquecido a gaze na traquéia do paciente, a segunda cirurgia sequer teria ocorrido. A $1^{\text {a }}$ série causal (acidente de trânsito) tampouco favoreceu a eficácia da $2^{\mathrm{a}}$ série (erro médico) que, em relações às complicações da traquéia, operou sozinha. Participaram do julgamento, além do Rel. Min. Ruy Rosado de Aguiar, os ministros Aldir Passarinho Junior, Barros Monteiro, Cesar Asfor Rocha e Sálvio de Figueiredo Teixeira. O Min. Aldir Passarinho foi o único que entendeu que não se poderia se estender a essa segunda lesão o nexo causal da responsabilidade do causador do acidente automobilítisco, pois, a seu ver, "ela[a segunda lesão] teria uma causa própria [o erro médico], senão haveria quase que um seguro de vida $a d$ eternum para quem fosse vitimado num acidente em função das circunstâncias supervenientes. Esse é o entendimento correto, mesmo à luz da Teoria da Causalidade Adequada, invocada no julgamento. Ocorre que, depois dos votos que se sucederam, o próprio Min. Aldir Passarinho, ao pedir vista dos autos, mudou de opinião. A decisão, foi, então, unânime, no sentido de responsabilizar o agente responsável pelo acidente até pelos custos da segunda cirurgia, isto é, pelo resultado danoso mais grave. (CRUZ, Gisela Sampaio da. op. cit., p. 164).

${ }^{153}$ Anderson Schreiber adverte: “ A transferência ou eliminação do peso da prova da culpa e a relativa desimportância da prova do nexo causal diante da sua flexibilização vêm acolhidas na prática jurisprudencial justamente com a finalidade, ideologicamente legítima, de garantir ao ofendido alguma indenização.

É evidente que, com isto, não se cancela a importância da culpa e do nexo causal na estrutura elementar da responsabilidade civil, mas tem-se, no âmbito desta mesma estrutura, um gradual deslocamento de foco que deixa a culpa e o nexo causal em direção ao dano. É sobre este último elemento que as atenções dos tribunais vêm se concentrando, podendo se afirmar que, hoje, o objetivo das cortes, na aplicação da responsabilidade civil, tem sido o de identificar um responsável que se vincule (pela sua culpa ou pela sua atividade) ao dano, e mais o de assegurar, por qualquer meio disponível, a integral reparação dos prejuízos sofridos pela vítima." (SCHREIBER, Anderson. Novas tendências da responsabilidade civil brasileira. RTDC: Revista Trimestral de Direito Civil, Rio de Janeiro, v. 6, n. 22, p. 56, abr./jun. 2005). 
como Caio Mario da Silva Pereira definiu, mais delicado dos elementos da responsabilidade civil; a sua flexibilização acarretará a uma responsabilização sem limites e sem critérios. ${ }^{154155}$

\subsection{Das excludentes de responsabilidade}

As excludentes de responsabilidade são as exceções. Serão identificadas quando não existir algum dos pressupostos da responsabilidade civil. Há que se fazer uma distinção entre a responsabilidade subjetiva e objetiva, na medida em que apenas a primeira tem como pressuposto a ilicitude e ou a culpabilidade do ato.

O âmbito de abrangência da reparação civil é tema de extrema relevância. O direito consiste exatamente em saber distinguir, mais especificamente para a responsabilidade civil, o que é passível de reparação do que não o é.

Em princípio, a interrupção do nexo causal é motivo para excluir o agente de qualquer responsabilidade.

A averiguação das excludentes de responsabilidade, muitas vezes, deve ser feita caso a caso, como se estivesse na raiz do acidente a solução do caso, assim é possível averiguar em quais circunstâncias o incidente ocorreu. Por exemplo: um assalto à mão

\footnotetext{
${ }^{154}$ O TJRJ assim decidiu: o nexo causal é a primeira questão a ser enfrentada na solução de demandas envolvendo responsabilidade civil e sua comprovação exige absoluta segurança quanto ao vínculo entre determinado comportamento e o evento danoso. (Apelação Cível 2004.001.10228, Rel. Des. Sergio Cavalieri Filho, j. 4.8.2004).

${ }^{155}$ Vale transcrever acórdãos que não foram caracterizados o dever de indenizar em razão da inexistência do nexo causal: “Ação ordinária. Responsabilidade civil médica. Erro médico. Nexo causal inexistente. Perícia técnica conclusiva. Obrigação de meio. Tendo a minuciosa perícia médica realizada comprovado que não houve qualquer erro no atendimento da autora, e que sua lesão era grave, de quase impossível recuperação total, não se pode falar em dever de indenizar, já que a obrigação que liga o médico e o paciente é de meios, e não de resultado. Não se trazendo, no recurso, qualquer elemento concreto e convincente, para ilidir as conclusões do laudo, deve ele prevalecer, para afastar a responsabilidade da ré, já que inexistente o vício do serviço." (Apelação Cível n 16.549/04. Décima Câmara Cível, Relator Des. Sylvio Capanema de Souza, j. 24/08/2004).

Civil e Processo Civil. Responsabilidade civil. Ação indenizatória. Erro. Médico. Responsabilidade da seguradora. Sentença de improcedência. Preliminares de prescrição e de ilegitimidade passiva da seguradora rejeitadas, a $1^{\text {a }}$ por se dirigir a menor e a $2^{a}$ frente à incidência da teoria da asserção. Parto normal com complicações imprevisíveis, conforme atestado por laudo pericial médico e sua complementação. Pretensão de realização de perícia complementar destituída de lastro consistente. Laudo peremptório acerca da ocorrência do fortuito médico. Inexistência de culpa, em qualquer de suas modalidades, a se imputar ao médico, que se utilizou dos procedimentos adequados à situação imprevisível, objeto de raro relato na literatura médica. Inexistência de violação do dever de cuidado. Exclusão da responsabilidade médica por inexistência de culpa e da ocorrência do caso fortuito. Ausência do nexo de causalidade tanto em relação ao médico como à seguradora. Improvimento do apelo." (Apelação cível $n^{\circ}$ 2005.001.00271, Terceira Câmara Cível, Relator Des. Luiz Fernando de Carvalho, 19/07/2005).
} 
armada dentro de um banco foi objeto de indenização, por outro lado, o Superior Tribunal de Justiça, excluiu a responsabilidade civil nos casos assaltos à mão armada no interior de ônibus, trens e metrôs, pois fundamentou a decisão ao afirmar que a empresa de transporte não deve ser punida por um fato inesperado e inevitável que não faz parte da atividade fim do serviço de condução de passageiros ${ }^{156}$.

É válido lembrar que para o STJ não foram considerados caso fortuito ou força maior: um buraco na via pública, um assalto à mão armada dentro de um banco e um urubu sugado pela turbina do avião que acarretou atraso de centenas de pessoas. Todos esses casos foram objeto de indenização.

Sem dúvida, tema polêmico é o fato da responsabilização nos assaltos ocorridos no interior de agências bancárias, ao contrário do que ocorre com as empresas de transporte, pois o Tribunal entende que o banco deve ser responsabilizado, já que zelar pela segurança dos clientes é inerente à atividade fim de uma instituição financeira ${ }^{157}$. Com a vênia devida é um posicionamento questionável, tendo em vista a atividade fím não ser zelar pela segurança dos clientes, mas movimentar os valores de suas contas.

\footnotetext{
${ }^{156}$ Nesse sentido o REsp 783743/RJ, de relatoria do Min. Fernando Gonçalves: "CIVIL. INDENIZAÇÃO. TRANSPORTE COLETIVO (ÔNIBUS). ASSALTO À MÃO ARMADA SEGUIDO DE MORTE DE PASSAGEIRO. FORÇA MAIOR. EXCLUSÃO DA RESPONSABILIDADE DA TRANSPORTADORA.

1. A morte decorrente de assalto à mão armada, dentro de ônibus, por se apresentar como fato totalmente estranho ao serviço de transporte (força maior), constitui-se em causa excludente da responsabilidade da empresa concessionária do serviço público.

2. Entendimento pacificado pela Segunda Seção.

3. Recurso Especial conhecido e provido.

(Quarta Turma, j. 12/12/2005, por unanimidade).

157 O STJ assim decidiu: "AGRAVO REGIMENTAL. PROCESSUAL CIVIL E CIVIL. NEGATIVA DE PRESTAÇÃO JURISDICIONAL NÃO CONFIGURADA. BANCO. ASSALTO. RISCO DA ATIVIDADE. ÔNUS DA PROVA. MATÉRIA FÁTICA. DEFICIÊNCIA NA FUNDAMENTAÇÃO RECURSAL. SÚMULA 284 DO STF. INDENIZAÇÃO. REVISÃO DO VALOR. ENUNCIADO 7 DA SÚMULA DO STJ.

1. Não há falar-se em negativa de prestação jurisdicional quando todas as questões necessárias ao deslinde da controvérsia foram analisadas e decididas, ainda que de forma contrária às pretensões do recorrente.

2. Este Tribunal Superior já se posicionou no sentido de estabelecer que nas discussões a respeito de assaltos dentro de agências bancárias, sendo o risco inerente à atividade bancária, é a instituição financeira que deve assumir o ônus desse infortúnios.

3. O Acórdão recorrido entendeu existente a hipossuficiência da parte a justificar a inversão do ônus da prova, levando em consideração aspectos fáticos da relação jurídica processual estabelecida nos autos e rever este entendimento encontraria óbice na súmula 7/STJ.

4. A não explicitação precisa, por parte do recorrente, sobre a forma como teriam sido violados os dispositivos suscitados atrai a incidência analógica do enunciado $\mathrm{n}^{\circ} 284$ da Súmula do STF, que dispõe ser "inadmissível o recurso extraordinário quando a deficiência na sua fundamentação não permitir a exata compreensão da controvérsia.

5. A revisão do quantum fixado a título de indenização revela-se possível somente quando o valor arbitrado nas instâncias originárias for irrisório ou exorbitante. Não estando configurada uma dessas hipóteses, incide o enunciado 7 da Súmula do STJ, a obstaculizar a sua reavaliação.

6. Agravo regimental a que se nega provimento."

(AgRg no Ag 962962/SP, relator Min. Carlos Fernando Mathias, Quarta Turma, j. 06/11/2008).
} 
Denota-se a divergência de interpretações que compõem a jurisprudência diante de fatos muito parecidos. Por isso torna-se difícil enquadrar a responsabilidade civil sob o prisma culpa, nexo causal e dano, na subjetiva e nexo causal e dano, na objetiva.

Vale lembrar a questão dos danos morais ressarcíveis baseados em aspectos eventuais e subjetivos como humilhação, dor, gravidade da ofensa ou até mesmo vexame. A gravidade da ofensa muitas vezes é parâmetro para indenizar ou não a suposta vítima, na medida em que, em muitos julgados, exclui-se a responsabilização pelo simples fato de que um mero dissabor não é motivo para ser considerado dano moral.

De fato, no intuito de proteger a vítima, os julgadores têm dispensado não apenas a culpa, mas principalmente o nexo causal, com a atenção voltada tão-somente para quem pode suportar o dano.

O objetivo dessa tendência, sem dúvida, é dar efetividade ao aspecto solidário constitucional. Com o pensamento voltado ao fato de que os danos não acontecem por acaso ou por fatalidade, mas por 'efeito colateral' da sociedade tem-se buscado a qualquer custo um 'culpado' pelo dano, principalmente se o réu é uma empresa.

Da mesma forma que manter a vitima irresarcida, é injusto atribuir aleatória e isoladamente o ônus da indenização. Impõe-se uma responsabilidade social para que o dever de reparar também seja solidarizado; contudo, o dever de indenizar em si continua arraigado ao individualismo o que traz prejuízos incomensuráveis a toda sociedade.

Percebe-se aumento considerável na responsabilização, principalmente, no que tem sido denominada a indústria do dano moral, o que tem aumentado o ajuizamento de demandas, tumultuando o Poder Judiciário com ações de massa nem sempre fundamentadas. Isso tem acontecido justamente porque não existem mais impedimentos aos pedidos indenizatórios, há muito tempo a culpa exerce papel coadjuvante, enquanto o nexo causal é tema por demais controvertido no âmbito jurisprudencial.

\subsubsection{Das excludentes de responsabilidade no âmbito do CDC}

Há que se ponderar que a responsabilidade pelo fato do produto consagrada no ordenamento jurídico pátrio, não adotou a teoria do risco integral, tendo em vista as possibilidades de excludentes. Com efeito, a responsabilidade pelo fato do produto é objetiva, mas não absoluta. 
No âmbito do Código de Defesa do Consumidor estão expressamente previstas as seguintes excludentes: a inexistência de defeito do produto ou serviço ${ }^{158}$; a não colocação do produto no mercado; e a culpa exclusiva do consumidor, pois se o comportamento do consumidor é o único causador do acidente de consumo, não há como falar em nexo de causalidade entre a atividade do fabricante e o fato danoso. Será causa de excludente de responsabilidade, da mesma forma, a ação exclusiva de terceiro ${ }^{159}$, atacando, justamente, o nexo de causalidade.

Igualmente, podem ser classificados como causas excludentes de responsabilidade, o caso fortuito e a força maior para impedir o dever de indenizar. ${ }^{160}$

O Código de Defesa do Consumidor em seu parágrafo $3^{\circ}$ do artigo 12 prevê as hipóteses em que o fornecedor não será responsabilizado. ${ }^{161}$

Com efeito, para o direito do consumidor é de extrema importância a noção do que seja a colocação do produto no mercado: o produto é considerado inserido no mercado quando é introduzido no "ciclo produtivo-distributivo" de forma voluntária e consciente.

Para o direito italiano, o Decreto 224/88, em seu artigo 7, c:

"Il prodotto è messo in circolazione quando sia consegnato all' acquirente, all' utilizzatore, o a un ausiliario di questi, anche in visione o in prova." 162

Para o Código Civil francês, nos termos do artigo 1386-5, o produto é colocado em circulação quando:

\footnotetext{
${ }^{158}$ Ao contrário da Diretiva da CEE o CDC não põe sobre os ombros do consumidor a prova do defeito; nos termos da legislação brasileira, o consumidor, em ação de responsabilidade civil por acidente de consumo, tem de provar apenas o dano e o nexo causal.

${ }^{159}$ João Calvão da Silva estabelece que: "terceiro será, naturalmente, qualquer pessoa estranha à relação entre o produtor e o lesado" (SILVA, João Calvão da. op. cit., p. 736).

Claudia Lima Marques nesse sentido afirma que: “ou, ainda, o Estado, quando, por má conservação de uma estrada, rompe-se uma das rodas do automóvel do consumidor, causando acidente fatal." (MARQUES, Claudia Lima; BENJAMIN, Antônio Herman; BESSA, Leonardo Roscoe. op. cit., p. 128).

${ }^{160}$ Nesse sentido, Claudia Lima Marques: "A regra no nosso direito é que o caso fortuito e a força maior excluem a responsabilidade civil. O Código, entre as causas excludentes de responsabilidade, não os elenca. Também não os nega. Logo, quer me parecer que os sistema tradicional, neste ponto, não foi afastado, mantendo-se, então, a capacidade do caso fortuito e da força maior para impedir o dever de indenizar." (MARQUES, Claudia Lima; BENJAMIN, Antônio Herman; BESSA, Leonardo Roscoe. op. cit., p. 128).

${ }^{161}$ Art.12, $\S 3^{\circ}$ : “O fabricante, o construtor, o produtor ou importador só não será responsabilizado quando provar:

I - que não colocou o produto no mercado;

II - que, embora haja colocado o produto no mercado, o defeito inexiste;

III - a culpa exclusiva do consumidor ou de terceiro."

${ }^{162}$ Em tradução simples: "O produto é colocado em circulação quando for entregue ao adquirente, ao usuário ou a um auxiliar destes, mesmo que para vista ou prova."
} 
"un produit est mis en circulation lorsque le producteur s'en est dessaisi volontairement."

Eduardo Arruda Alvim entende que:

"Desde, pois, que o fornecedor tenha colocado o produto no mercado para comercialização, ainda que, por exemplo, simplesmente para teste, ou mesmo oferecendo o produto como amostra grátis, não poderá alegar excludente. É necessário, portanto, para que se possa alegar esta excludente, que a introdução do produto no mercado não se tenha dado por ato consciente e voluntário." 164

É requisito para a excludente de responsabilidade que o produto não tenha sido levado à comercialização pela livre decisão do fornecedor.

Flávia Portella Puschell considera que um produto é colocado no mercado quando seu fornecedor, considerando o bem apto para a comercialização, o transfere a terceiro, perdendo, assim, o poder de controle sobre a coisa ou, no caso de bens de produção própria, passa a utilizá-lo. ${ }^{165}$

De fato, o fornecedor, impreterivelmente, tem que ter colocado o produto no mercado para que haja sua responsabilização, portanto, na hipótese de falsificação do produto ou roubo, também o dano ocorreu de maneira involuntária, do que se concluiu que a excludente se faz presente. $\mathrm{O}$ fornecedor também será isento de responsabilidade quando provar que não desenvolveu o produto ou que o suspendeu antes de entrar em circulação.

A segunda hipótese prevista pelo CDC é a inexistência de defeito no momento em que houve a introdução no mercado; nesse caso o nexo causal foi interrompido, ou seja, o fornecedor será eximido de responsabilidade se provar que o defeito causador do dano não existia no momento em que colocou o produto no mercado.

A supracitada autora observa que o verbo existir, empregado pela norma, no artigo $12, \S 3^{\circ}$, II, no tempo presente, parece indicar simplesmente a exigência de que haja um defeito do produto no momento da ocorrência do dano. ${ }^{166} \mathrm{O}$ que significa dizer que o defeito resulta de fato ocorrido após a colocação do produto no mercado, isto é, quando o

\footnotetext{
${ }^{163}$ Em tradução simples: “ um produto é colocado em circulação quando o produtor dele se desfaz volutnariamente."

${ }^{164}$ ALVIM, Eduardo Arruda. Responsabilidade civil por fato do produto no Código de Defesa do Consumidor. Belo Horizonte: Del Rey, 1996. p. 118.

${ }^{165}$ PUSCHEL, Flavia Portella. op. cit., p. 132.

${ }^{166}$ Id. Ibid., p. 136.
} 
fornecedor não possui mais poder de controle ou influência sobre a coisa, não sendo possível atribuir um dos fundamentos da atribuição da responsabilidade por acidentes de consumo ao fornecedor.

O momento da colocação do produto no mercado, sem defeito, é o fator decisivo para que o fornecedor não seja responsabilizado.

$\mathrm{Na}$ ausência de nexo causal entre o produto e o suposto dano, obviamente, aplicar-se-á a excludente.

Vale transcrever trecho da prova testemunhal do médico em ação indenizatória, a qual, por unanimidade, foi negado provimento ao recurso da autora, pelo Tribunal de Justiça do Estado de Minas Gerais, pois esta não conseguira comprovar o defeito do produto:

“ que não tem condições de afirmar com certeza qual foi a causa da
'endoftalmite' que acometeu a autora, mesmo porque pode essa infecção
ter inúmeras causas... que foi informado pelo mesmo colega que,
extraído material do olho da autora, com a finalidade de exame
bacteriológico capaz de detectar a causa da infecção, o resultado foi que,
até aquele momento não havia crescido qualquer germe patológico,
continuando, pois, indefinida a causa da infecção havida no olho da
autora sob a forma aguda, que se constata em torno de 24 horas até os
cinco dias seguintes ao pós-operatório; que além do agente
bacteriológico, a 'endoftalmite' pode ter agente causador em fungos,
bem como por reações anafiláticas, ou seja, de natureza alérgica." 167

$\mathrm{Na}$ demanda supracitada os desembargadores entenderam que a decisão monocrática foi acertada, tendo em vista a autora/apelante ter preferido o simples juízo hipotético ao invés de provar o nexo causal direto e imediato do fato com a fornecedora do medicamento, não sendo possível saber sequer se a lesão não teve origem em outras causas, tais como, infecção hospitalar, processo alérgico, trauma, deficiência orgânica do paciente, pós-operatório incorreto, ou até do próprio ato cirúrgico.

Para que haja a responsabilização do fornecedor não é suficiente o dano, mas sim que este tenha decorrido de um defeito do produto, a cadeia se completa quando estiverem configurados o defeito, o dano e o nexo de causalidade.

No que concerne à classificação dos defeitos, James Marins os classifica em produtos juridicamente relevantes e juridicamente irrelevantes, sendo relevantes aqueles

\footnotetext{
${ }^{167}$ (Ap Cív, 1.064.06.000127-7/001 - Comarca de Santo Antônio do Monte - Apelante: Jovita Alves dos Santos - Apelada: Oft Vision Indústria e Comércio Ltda. - Relator: DEs.Osmando Almeida).
} 
enumerados no caput do artigo 12 do CDC, isto é, defeitos de concepção, de produção e de informação. Para o autor esses defeitos apenas podem surgir antes da colocação; ocorridos, posteriormente, o fornecedor não poderá ser responsabilizado. ${ }^{168}$

Para Claudio Luiz Bueno de Godoy, o defeito pode ser considerado uma quebra na qualidade que se espera do produto ou do serviço. E adiante complementa que o Código de Defesa do Consumidor exige um dado qualificativo especial do nexo de causalidade, que está na noção de defeito. ${ }^{169}$ Sem dúvida, é requisito indispensável para que se atinja um sistema sem desequilíbrios, o que significa dizer sem carga excessiva ao fornecedor.

A caracterização do defeito se manifestaria por meio da ausência da segurança legitimamente esperada do produto ou serviço.

Por último, a culpa exclusiva do consumidor ou de terceiro exclui a responsabilidade do fornecedor, desde que este prove que aqueles agiram com culpa. Nessa última hipótese, a vítima está plenamente ciente da existência do defeito e do risco; muito embora esteja relacionado com o defeito, o dano decorre exclusivamente do ato voluntário e consciente da vítima.

Para a Diretiva 85/374 da CEE, a culpa concorrente da vítima pode ser não apenas reduzida, como até excluída, nos termos do artigo 8, II. (transcrever o artigo)

No que concerne à culpa concorrente da vítima, a concorrência de fato da vítima como causa para o surgimento do dano, não exclui a responsabilidade do fornecedor. ${ }^{170}$

Dessa forma, o CDC não pretende estabelecer um sistema de segurança absoluta para os produtos e serviços, mas sim a segurança dentro dos padrões da expectativa legítima dos consumidores, tendo por base a concepção coletiva da sociedade de consumo.

\footnotetext{
${ }^{168}$ SOUZA, James Marins de. Risco de desenvolvimento e tipologia das imperfeições dos produtos. Revista de Direito do Consumidor, São Paulo, ano 17, n. 67, p. 149-150, jul./set. 2008.

${ }^{169}$ GODOY, Claudio Luiz Bueno de. Responsabilidade civil pelo risco da atividade: uma cláusula geral no Código Civil de 2002. São Paulo: Saraiva, 2009. p. 74 e 76.

${ }^{170} \mathrm{O}$ STJ considerou que a culpa concorrente da vítima permite a redução da condenação do fornecedor, no seguinte julgado: “CDC. Responsabilidade do fornecedor. Culpa concorrente da vítima. Hotel. Piscina. Agência de viagens.

- Responsabilidade do hotel, que não sinaliza convenientemente a profundidade da piscina, de acesso livre aos hóspedes. Art.14 do CDC;

- A culpa concorrente da vítima permite a redução da condenação imposta ao fornecedor. Art. 12, §2, II, do CDC.

- A agência de viagens responde pelo dano pessoal que decorreu do mau serviço do hotel contratado por ela para a hospedagem durante o pacote de turismo.

(REsp n ${ }^{\circ}$ 287.849/SP, Rel. Min. Ruy Rosado de Aguiar, j.17/04/2001).
} 
E dentro desse panorama, questiona-se se o risco do desenvolvimento seria ou não uma excludente de responsabilidade, já que no momento em que o produto foi colocado em circulação não era possível detectar a existência do defeito. 


\title{
CAPÍTULO V. DO RISCO DO DESENVOLVIMENTO
}

\begin{abstract}
SUMÁRIO: 5. DO RISCO DO DESENVOLVIMENTO E LEGÍTIMA EXPECTATIVA DO CONSUMIDOR. 5.1. - DO RISCO DO DESENVOLVIMENTO COMO EXCLUDENTE DE RESPONSABILIDADE. 5.1.1 - DA PRESCRIÇÃO DA PRETENSÃO. - 5.2. - DO PRINCÍPIO DA LEGALIDADE E A LIBERDADE DE ESCOLHA - 5.3. DO PRINCÍPIO DA PRECAUÇÃO - 5.4. -DO DESENVOLVIMENTO CIENTÍFICO E TECNOLÓGICO - 5.5. DA DISTRIBUIÇÃO DOS PREJUÍZOS - 5.5.1. DOS SEGUROS - 5.5.2 - DO FUNDO GARANTIDOR.
\end{abstract}

\section{Do risco do desenvolvimento e legítima expectativa do consumidor}

O conceito dos riscos do desenvolvimento ${ }^{171}$ não é unânime na doutrina, inclusive é alvo de críticas, pois o desenvolvimento da ciência não pode ser interpretado como risco, na medida em que a intenção é precisamente eliminá-lo.

É o risco que somente vem a ser descoberto após certo período de uso do produto e do serviço, pois no momento do lançamento nada é identificado.

Silmara Juny de Abreu Chinellato e Antônio Carlos Morato ressalvam que a Doutrina conceitua o risco do desenvolvimento como o que não pode ser cientificamente conhecido quando do lançamento do produto no mercado, considerando-se o estado da arte, e que foi descoberto apenas depois de certo tempo de seu uso. ${ }^{172}$

Para Antônio Herman Benjamin, risco do desenvolvimento é aquele risco que não pode ser cientificamente conhecido ao momento do lançamento do produto no mercado, vindo a ser descoberto somente após um certo período de uso do produto e do serviço. ${ }^{173}$

Teresa Ancona Lopez observa que são riscos conhecidos muito depois do produto estar no mercado e para os quais não houve informação prévia, pois também desconhecidos de seu fabricante. ${ }^{174}$

\footnotetext{
${ }^{171}$ Risque du development na expressão francesa e development risk na inglesa.

${ }^{172}$ CHINELLATO, Silmara Juny de Abreu; MORATO, Antonio Carlos. In: NERY, Rosa Maria; DONINI, Rogério (Coords.). Responsabilidade civil: estudos em homenagem ao professor Rui Geraldo Camargo Viana. São Paulo: Ed. Revista dos Tribunais, 2009. p. 29.

${ }^{173}$ BENJAMIN, Antônio Herman.op. cit., p. 67.

${ }^{174}$ LOPEZ, Teresa Ancona. op. cit., p. 15.
} 
Os riscos do desenvolvimento significam o quanto de incerteza pode existir quanto ao conhecimento da atualidade, no que concerne aos produtos e serviços disponibilizados no presente momento.

A supracitada autora observa que a segurança do produto estaria na correspondência às legítimas expectativas do consumidor, quanto à sua apresentação, ao seu uso e aos riscos que razoavelmente dele se espera, dependendo da época em que foi colocado no mercado ("state of art"). Entretanto, sob o ângulo econômico, segundo a autora, o defeito do produto seria analisado de acordo com o balanceamento do seu risco com a sua utilidade teste risco-utilidade e justamente este é que poderia entrar na expectativa do consumidor. Será o consumidor que, conhecendo os riscos dos produtos, por meio das informações obrigatórias dos fabricantes, escolherá por adquiri-los e usá$\operatorname{los}^{175}$

James Marins define como a possibilidade de que um determinado produto venha a ser introduzido no mercado sem que possua defeito cognoscível, ainda que exaustivamente testado, ante o grau de conhecimento de conhecimento científico disponível à época de sua introdução, ocorrendo todavia que, posteriormente, decorrido determinado período do início de sua circulação no mercado de consumo, venha a se detectar defeito, somente identificável ante a evolução dos meios técnicos e científicos, capaz de causar danos aos consumidores. ${ }^{176}$

João Calvão da Silva observa:

"não sendo o estado da arte um conceito determinado e fechado, mas um conceito movente carecido de aferição nas circunstâncias do caso, a sua moldura deve ser a possibilidade científica e técnica que se haja imposto no respectivo domínio e tenha passado a estar à disposição geral, mesmo

\footnotetext{
${ }^{175}$ Teresa Ancona Lopez adverte: João Calvão da Silva, declaradamente um não-fumante, diz que o fumante não quer saber se o cigarro causa câncer, (...) "vai morrer feliz e contente, diferente de você que nem sabe o que é o prazer de fumar. Acho isso delicioso. Cada um goza o prazer que quer. Gosto mais de outros prazeres. Tudo que é exagerado pode dar mau resultado. É igual a bebida alcoólica. Quem não sabe que beber pode fazer mal ?

Em suma, fumar ou beber ou praticar esportes radicais é escolha individual, se dá no exercício da liberdade protegida constitucionalmente. Como valor, a liberdade integra a personalidade enquanto seu contorno essencial, de início no sentido positivo de criatividade, de expressão do próprio ser da pessoa, da capacidade de inovar, e, em seguida, em um sentido negativo de não ser impedido (grifos nossos).

Adiante esclarece: "A interferência do público no privado, que começou com as restrições, de todos os tipos, ao fumo (e as consequentes ações contra essa indústria) veio mexer com a capacidade das pessoas responderem, no uso de sua liberdade, por suas escolhas; perceberam os cidadãos que cabia ao Estado avaliar suas condutas haviam sido perigosas mesmo que no uso de seu livre-arbítrio. Ao Estado só cabe definir as políticas públicas de cada segmento e nunca interferir na vida íntima da família, onde caberá a seus membros decidir o que é melhor para cada qual; 'Ao Estado atribui-se a função de proteger a liberdade e jamais de cerceá-la; nas palavras de Tércio Ferraz Jr.' (LOPEZ, Teresa Ancona. op. cit., 16).

${ }^{176}$ SOUZA, James Marins de. op. cit., p. 128.
} 
que não seja ainda a praticada no respectivo ramo industrial. Ao acatamento deste novo e mais atual estado geral da ciência e da técnica, sem fronteiras ou limites territorias, é que o produtor está vinculado, e não a um anterior, ainda que vazado na práxis industrial." ${ }^{177}$

Para o autor supracitado, o estado da arte ou estado da ciência e da técnica é critério da cognoscibilidade do defeito e não do padrão da conduta do produtor. ${ }^{178}$

Adiante elucida:

"Deste modo, o estado dos conhecimentos técnicos e científicos, tal como o entendemos, constitui a pedra de toque da responsabilidade ou irresponsabilidade do produtor: da responsabilidade pelos defeitos de concepção e informação; da irresponsabilidade pelos riscos do desenvolvimento". ${ }^{179}$

Distingue-se da hipótese prevista no $\S 2^{\circ}$ do artigo 12 do CDC que estabelece que o produto não é considerado defeituoso pelo fato de outro de melhor qualidade ter sido colocado no mercado, ou seja, não induz à conclusão de que os mais antigos sejam considerados defeituosos, já que o contexto da época de lançamento do produto deve ser analisado. Entretanto, ainda que o risco do desenvolvimento seja hipótese distinta percebese a intenção do legislador, na medida em que o produto deve ser adequado para o momento em que foi inserido no mercado. Com efeito, o avanço tecnológico faz com que os produtos atuais sejam mais seguros e eficientes do que os do passado que podem apresentar maior grau de risco.

De fato, a dificuldade é compatibilizar o risco do desenvolvimento com a legítima expectativa do consumidor. Sem dúvida, no momento em que o legislador prevê que a segurança que dele legitimamente se espera levou em consideração as expectativas do público em geral e os destinatários de seus produtos ou serviço. ${ }^{180}$

\footnotetext{
${ }^{177}$ SILVA, João Calvão da. op. cit., p. 512.

${ }^{178}$ Id. Ibid., p. 513.

${ }^{179}$ Id. Ibid., p. 521.

${ }^{180}$ Nesse sentido, Paulo Jorge Scartezzini Guimarães adverte: “Quando o legislador fala em 'segurança que dele legitimamente se espera' não está criando um conceito subjetivo, em que se levam em conta as expectativas do lesado, mas sim um conceito objetivo, pois deve-se ter em consideração as expectativas do público em geral e os destinatários daquele produto ou serviço (crianças, idosos, homens, mulheres, deficientes etc.).

A verificação da defeituosidade dar-se-á pelo magistrado, observando cada caso; todavia o legislador alinhou algumas circunstâncias que deverão ser analisadas."

E adiante acrescenta: " A verificação da possibilidade ou não de o fornecedor conhecer o defeito deve ser vista com cautela. Aqueles que aceitam a exclusão da responsabilidade por força do development risk,
} 
Questiona-se se efetivamente esta expectativa foi transgredida. Será que realmente há nessas hipóteses um problema de adequação entre produto e a legítima expectativa do consumidor ? ${ }^{181}$ Parece que há uma supervalorização da expectativa do consumidor ao se pretender a responsabilização por defeito desconhecido, diante de parâmetros universais.

Há que se reconhecer a legitimidade da expectativa da sociedade com relação à segurança do produto, sendo um dos fatores indicativos o uso e riscos que dele razoavelmente se podem esperar. É importante lembrar que nem todo produto perigoso é defeituoso para efeitos de responsabilidade por acidentes de consumo.

Além disso, deve-se observar que, tanto no direito brasileiro, quanto no direito estrangeiro, não se exige uma segurança absoluta dos produtos. Há de se atentar para as

somente porque a lei os obriga, tendem a dizer que qualquer desenvolvimento científico que pudesse demonstrar o risco do produto seria causa suficiente para a manutenção da responsabilidade.

Entendemos mais prudente outra corrente, e, assim,, por exemplo, se a descoberta científica ocorreu em um pequeno país asiático e foi divulgada em um periódico de pequena circulação, não terá tal fato o condão de impossibilitar esse meio de defesa. Solução oposta ocorreria quando o estudo foi realizado, por exemplo, nos Estados Unidos ou na Europa e publicado em revista de penetração no mundo científico.

Tal isenção de responsabilidade, entretanto, deixará de existir se, após colocado o produto no mercado, e conhecido o defeito, não se tomarem as providências necessárias para evitar danos (dentro os quais, os previstos nos $\S \S 1^{\circ}$ e $2^{\circ}$ do art. 10 da Lei 8.078/90).

O problema pode ser facilmente visualizado na atividade das indústrias farmacêuticas. Se no momento de elaborar uma fórmula medicinal não se tinha conhecimento (através de meios técnicos e científicos disponíveis no mercado) dos perigos de determinada substância utilizada, não se pode imputar-lhes qualquer responsabilidade pelos danos causados aos usuários.

É óbvio que a questão é delicada e deve ser analisada com cautela; ademais, cabe ao fornecedor, nos termos do inciso II do $\S 3^{\circ}$ dos arts. 12 e 14, comprovar que agiu da forma mais prudente possível." (GUIMARÃES, Paulo Jorge Scartezzini. Vícios do produto e do serviço por qualidade, quantidade e insegurança: cumprimento imperfeito do contrato. 2. ed. rev. atual. e ampl. São Paulo: Ed. Revista dos Tribunais, 2007. p. 294-295).

${ }^{181}$ Flávia Portella Puschell observa que: “As expectativas dos indivíduos são por vezes altas demais, por vezes exageradamente baixas, em função de fatores como a sua falta de conhecimento a respeito das condições técnicas de produção.

Diante disso, há autores que defendem a adoção de um tipo ideal de consumidor, o consumidor médio, como padrão para o estabelecimento da legítima expectativa de segurança.

Ao contrário, há quem rejeite a adoção de qualquer espécie de consumidor como padrão, seja o consumidor concreto, seja o consumidor médio. (...)

Entretanto, na realidade o que existe são várias expectativas individuais concretas, as quais, como se viu, não podem ser a base para determinação da expectativa legítima de acordo com a lei. Portanto, a legítima expectativa da sociedade só pode ser uma expectativa ideal.

Sendo assim, a legítima expectativa de segurança da sociedade acaba por ser a expectativa de um homem médio ideal, ou seja, do bonus paterfamilias

Tomando-se o homem médio como padrão, evita-se o inconveniente de adotar o ponto de vista do consumidor, com exclusão dos bystanders, ao mesmo tempo em que se toma como medida um sujeito capaz de refletir a expectativa de toda a sociedade. Essa expectativa deve ser legítima, isto é, razoável diante da realidade existente no campo de produção e circulação do produto em questão.

Outrossim, ressalte-se que o padrão para avaliação da expectativa legítima deve ser um sujeito consciente de seus próprios deveres de segurança relativos à utilização de produtos. Deve tratar-se de um sujeito disposto a empregar o seu conhecimento a respeito dos perigos envolvidos no emprego do produto em seu interesse próprio e também na garantia da segurança de terceiros." (PUSCHEL, Flavia Portella. op. cit., p. 101). 
expectativas do público, pois tem que se aferir se da utilização razoável do produto os riscos eram esperados. Com efeito, tais circunstâncias contribuirão para que se saiba se o grau de segurança é o esperado.

Até que ponto o fornecedor responde pelos danos desconhecidos, diante de uma sociedade cada vez mais exigente e industrializada ? Incontestavelmente, os riscos devem ser submetidos à análise do ordenamento jurídico, mas essa submissão não pode ser feita sem parâmetros, na medida em que são desconhecidos na época em que foram introduzidos no mercado.

Não há defeito imputável ao fornecedor quando, nos termos do artigo $12, \S 1^{\circ}$, inciso III do CDC, tendo em conta a época e o conhecimento científico quando foi posto em circulação, inexiste vício de insegurança, consubstanciado na ruptura entre o funcionamento do produto ou serviço e o que deles espera legitimamente o consumidor.

Indiscutivelmente, há que se buscar a igualdade substancial na relação de consumo, entretanto, ao mesmo tempo, não pode o Estado tratar seus cidadãos como inaptos na escolha de produtos que desejam adquirir e os riscos que gostariam de assumir, ainda que, posteriormente, o avanço tecnológico apure os efeitos que os produtos possam causar.

Nessa seara, não houve violação à legítima expectativa do consumidor, nos termos das regras do CDC, pois nem o próprio fornecedor tinha condições de aferir os malefícios que poderia causar; no risco do desenvolvimento, a expectativa tem que se limitar ao avanço científico da época ${ }^{182}$ e não ao que posteriormente se conseguiu descobrir com a realização de pesquisas. ${ }^{183}$

Frise-se que são riscos não conhecidos pelo mais avançado estado da ciência e da técnica, no momento da introdução do produto no mercado de consumo, e que só são descobertos após determinado período de uso do mesmo, em decorrência do avanço dos estudos científicos. $^{184}$

\footnotetext{
${ }^{182}$ Ugo Carnevale considera que não devem ser considerados como integrantes do estado dos conhecimentos técnicos e científicos, os conhecimentos adquiridos pelos laboratórios de pesquisa, e mantidos em segredo por estes em vista de fins comerciais ou industriais, salvo se ficar demonstrado que o fornecedor teve acesso a estes conhecimentos "secretos". (CARVENALI, Ugo. op. cit., p. 221). Responsabilizando apenas o fornecedor que teve acesso aos conhecimentos.

${ }^{183}$ Vale citar uma frase já conhecida: "remédio mais caro é aquele que não existe."

${ }^{184}$ Fabio Ulhoa Coelho defende que " as informações prestadas ao consumidor teriam sido adequadas e suficientes, conforme o que o conhecimento humano especializado podia, realmente, antever." (COELHO, Fabio Ulhoa. op. cit., p. 84).
} 
O defeito não cognoscível, ainda que exaustivamente testado, ante o grau de conhecimento científico disponível à época de sua introdução, após a circulação do produto no mercado pode ensejar danos aos consumidores, porém em que medida, por outro lado, é possível responsabilizar o fornecedor; em poucas palavras, seria o que justificaria a abordagem do tema.

Exemplificativamente, o cigarro foi introduzido no mercado sem a comprovação dos seus malefícios à saúde das pessoas; atualmente, porém, mesmo sabendo da possibilidade da ocorrência de doenças pelo fumo, o produto ainda assim não foi retirado do mercado, apenas exige-se uma advertência no produto, pelo fato de se atribuir a assunção dos riscos às possíveis vítimas.

Para Gustavo Tepedino, os riscos do desenvolvimento seriam uma excludente de responsabilidade do fornecedor, na medida em que não estariam presentes os elementos da responsabilidade civil pelo fato do produto. ${ }^{185}$

Exige-se a presença de três elementos para a caracterização da excludente de responsabilidade e que no entender do supracitado autor não estariam presentes, uma vez que, na época em que o produto foi colocado no mercado, inexistia vício de insegurança, consubstanciado na ruptura entre o funcionamento do produto ou serviço, que deles espera legitimamente o consumidor, com base no atual conhecimento científico.

Assim, pode-se afirmar que é lícito ao fornecedor inserir no mercado de consumo produtos dos quais não saiba, nem deva saber, resultem efeitos perigosos, principalmente, porque o grau de conhecimento científico à época da introdução do produto no mercado de consumo não permitia tal conhecimento. ${ }^{186}$ Frise-se que defeito não se confunde com nocividade, na medida em que existem inúmeros produtos nocivos, mas que não são defeituosos.

Com efeito, a aferição do estado da arte, por meio de opiniões técnicas, não se faz segundo opinião isolada, mas baseada em estudo com experimentação e acessibilidade aos cientistas e técnicos. ${ }^{187}$

É contrário ao interesse do próprio consumidor considerar produtos, que à época de sua colocação no mercado correspondiam à legítima expectativa da sociedade,

\footnotetext{
${ }^{185}$ TEPEDINO, Gustavo. A responsabilidade por acidentes de consumo na ótica civil-constitucional, cit. ${ }^{186}$ SOUZA, James Marins de. Risco de desenvolvimento e tipologia das imperfeições dos produtos. Revista de Direito do Consumidor, São Paulo, n. 6, p. 127, abr./jun. 1993.

${ }^{187}$ CHINELLATO, Silmara Juny de Abreu; MORATO, Antonio Carlos. op. cit., p.43.
} 
defeituosos, com o passar do tempo. Inclusive poderia acarretar uma elevação da expectativa de segurança da sociedade da qual resultaria automaticamente a sua responsabilização.

Outro aspecto importante é o fato de serem a ciência e a técnica relativas, ou seja, nunca será possível algo ser absoluto e sem margem à correção ulterior, em virtude do progresso.

Nesse sentido, julgado do TJRS:

Ao contrário do asseverado pela autora, já de muito se tem ampla e plena ciência de que o cigarro é fator de risco para a incidência de diversas doenças, já em 1950, os Estados Unidos e a Inglaterra confirmam, através de pesquisas, que o tabagismo é um fator importante na bronquite crônica e câncer de pulmão. Idêntica situação ocorre com o uso e riscos que razoavelmente dele se esperam, posto que já definido que os malefícios do fumo são de conhecimento notório há larga data, ensejando que seja razoavelmente risco de incidência de diversas doenças. Aliás, a própria previsão do inciso III do $\underline{\S} \underline{1^{0}} \underline{\text { do }} \underline{\text { referido }}$ art. 12 determina que se considere a época que o produto foi colocado em circulação para se avaliar a periculosidade do mesmo. Concluo, por estas razões, que não restou demonstrada a existência de defeito no produto ou deficiência ou inadequacão das informacões prestadas pelo fornecedor ao consumidor.

Além disso, há que se reconhecer a dificuldade do fabricante em repartir com seus consumidores, através de preços mais elevados, um risco desconhecido; o fornecedor pode apenas fazer meras conjecturas ou projeções.

Para James Marins de Souza não são defeitos de criação, produção ou tampouco de informação, pois não era cognoscível pelo homem. ${ }^{189}$ Devido a incognoscibilidade absoluta do defeitoe pela utilidade que o produto prestaria à sociedade a isenção de responsabilidade deve prevalecer.

Por outro lado, há quem acredite que a responsabilização desencorajaria a descoberta de novos produtos. De fato, o CDC não estabelece um sistema de segurança absoluto; o que se quer é uma segurança dentro dos padrões da expectativa legítima dos consumidores, sem, entretanto, considerar o consumidor invariavelmente uma vítima. ${ }^{190}$

\footnotetext{
${ }^{188}$ Apelação Cível 70005294855, 9 a Câmara, j. 02.06.2004.

${ }^{189}$ SOUZA, James Marins de. Risco de desenvolvimento e tipologia das imperfeições dos produtos. Revista de Direito do Consumidor, n. 6, cit., p. 127.

${ }^{190}$ Interessante reportagem da revista Exame ilustra bem a questão: “Até que, em meados de 2000, a francesa Danone, um dos maiores grupos de alimentos do mundo, descobriu meio sem querer que um de seus
} 
O consumidor não pode ser considerado individualmente, mas, ao contrário, deve haver uma concepção coletiva da sociedade de consumo.

\subsection{Do risco do desenvolvimento como excludente de responsabilidade}

Diante da problemática indaga-se a possibilidade de se incluir o risco do desenvolvimento como excludente de responsabilidade à luz do Código de Defesa do Consumidor e da Diretiva 85/374/CEE. ${ }^{191}$

A impossibilidade absoluta e objetiva de descobrir a existência do defeito impediria, a nosso ver, a responsabilização do fornecedor, em virtude da falta ou insuficiência de meios técnicos e científicos idôneos. ${ }^{192} \mathrm{~A}$ legítima expectativa do consumidor não teria sido violada, pois há que se admitir um standard de fornecedor ideal no mundo globalizado do consumo.

De fato, na época em que foi colocado no mercado correspondeu ao que poderia se esperar do produto no momento de sua circulação, a incognoscibilidade é absoluta.

iogurtes utilizava uma bactéria capaz de melhorar o trato digestivo - sem comprometer o sabor do produto. Foi o que bastou para que se criasse uma febre em torno dos chamados alimentos funcionais. Da noite para o dia, produtos até então rechaçados por um grupo crescente de consumidores, como refrigerantes e margarinas, passaram a contar com aditivos como vitaminas, minerais e outros nutrientes. E - mais importante - ganharam o rótulo de saudáveis. Uma recente pesquisa realizada nos Estados Unidos com as 500 maiores empresas de alimentos dos país mostrou que mais da metade delas passou a adicionar nutrientes a seus produtos neste ano apenas para incluí-los na categoria de funcionais;

Diante de todo esse frenesi, era de imaginar que reinasse entre companhias e consumidores um clima de otimismo e confiança com relação a esses produtos, certo? Pois o que está acontecendo é justamente o contrário. No início de novembro, a americana Kellogg's decidiu retirar do mercado um de seus maiores sucessos, o cereal Cocoa Krispies, vendido somente nos supermercados dos Estados Unidos. Enriquecido com antioxidantes, o produto trazia em sua embalagem a promessa de fortalecer o sistema imunológico das crianças. Mas, com a iminente disseminação do vírus H1N1 no país durante o inverno, a empresa achou por bem modificar o rótulo do produto - sob pena de enfrentar na Justiça a fúria de pais que eventualmente se sentissem enganados por estar com seus filhos doentes em casa, a despeito das tigelas de Cocoa Krispies oferecidas aos pimpolhos.

A atitude da Kellogg's, embora compreensível, deve ser entendida como mais do que simples preocupação com o bem-estar dos consumidores ou com a reputação de sua marca. Desde o início do ano, as autoridades de saúde e defesa do consumidor dos Estados Unidos têm apertado o cerco contra os fabricantes de alimentos funcionais - não tanto pela eficácia dos produtos, mas pelas promessas que seus rótulos carregam. Ao todo, mais de 40 companhias já foram acionadas judicialmente por esses órgãos, mais do que o dobro do ano passado." (reportagem veiculada em 02/12/2009, Olivia Fraga).

${ }^{191}$ Silmara Juny de Abreu Chinellato e Antonio Carlos Morato favoráveis à responsabilização do fornecedor advertem que: “ Logo, a falta da necessária diferenciação entre produto perigoso e risco do desenvolvimento tem levado alguns doutrinadores a sustentar que este teria sido admitido pelo direito brasileiro como excludente de responsabilidade do fornecedor." (CHINELLATO, Silmara Juny de Abreu; MORATO, Antonio Carlos. op. cit., p. 30).

${ }^{192}$ Nesse sentido, SILVA, João Calvão da. Compra e venda de coisas defeituosas: conformidade e segurança. Coimbra: Almedina, 2002. p. 200 e SOUZA, James Marins de. Risco de desenvolvimento e tipologia das imperfeições dos produtos. Revista de Direito do Consumidor, n. 6, cit., p. 125. 
Parte-se do pressuposto que houve uma prévia análise do mercado universal antes de ser introduzido, sendo ônus do fornecedor a prova da impossibilidade do conhecimento do defeito.

No âmbito da comunidade europeia a tendência é a de implementar a integração entre os estados-membros, através de um número cada vez maior de diretivas.

Muito embora, inicialmente, tenham sido feitas diretivas mínimas, ou seja, foram consagrados objetivos mínimos para cada país transpô-los com seus próprios meios, com a sua própria cultura jurídica, tal fato prejudicou a harmonização, principalmente no âmbito do comércio, da concorrência internacional. ${ }^{193}$

No que concerne ao risco do desenvolvimento, após acirrada discussão e votação a Comissão de assuntos jurídicos e do mercado interno exonerou o fornecedor da responsabilidade pelos riscos do desenvolvimento, nos termos do artigo $7^{\circ}$ da Diretiva 85/374/CEE.

É válido transcrever o artigo supracitado:

"O produtor não é responsável nos termos da presente directiva se provar:a) que não colocou o produto em circulação; b) que, tendo em conta as circunstâncias, se pode considerar que o defeito que causou o dano não existia no momento em que o produto foi por ele colocado em circulação ou que este defeito surgiu posteriormente; c) que o produto não foi fabricado para venda ou para qualquer outra forma de distribuição com um objectivo econômico por parte do produtor, nem fabricado ou distribuído no âmbito da sua actividade profissional; d) que o defeito é devido à conformidade do produto com normas imperativas estabelecidas pelas autoridades públicas; e) que o estado dos conhecimentos científicos e técnicos no momento da colocação em circulação do produto não lhe permitiu detectar a existência do defeito; f) no caso do produtor de uma parte componente, que o defeito é

\footnotetext{
${ }^{193}$ Antonio Pinto Monteiro em entrevista concedida à RTDC pondera que: "Isso prejudica a harmonização e prejudica, no âmbito do comércio internacional, da concorrência internacional, as empresas do estado mais eficiente. Um estado mais amigo do consumidor cria mais obrigações às empresas. Sendo assim, as empresas, no comércio internacional, estão em desvantagem para com as outras empresas de outro estado, menos amigo do consumidor e, portanto, com menos exigências. Isso faz com que, atualmente, a tendência siga para as diretivas de harmonização plena. Aí cada vez fica menos espaço de atuação para o estadomembro, cada vez há maior aproximação do Direito conquistado via Bruxelas, por via das diretivas comunitárias. Mas isso também tem o seu aspecto negativo. As diretivas nem sempre têm grande rigor, nem sempre têm grande qualidade, são muitas vezes feitas por funcionários, por técnicos, são compromissos políticos entre países diferentes experiências e culturas. O grande debate hoje dá-se entre os países do Common Law - Inglaterra, países nórdicos - e os países de Direito Continental - Portugal, Alemanha, Itália, França, Espanha. Há um frente a frente para ver se há aproximações, se há pontes entre os países de influência continental e os países do Common law. Aquilo que para um inglês é facilmente compreensível, para um italiano, um português e um alemão não é, vice-versa." (MONTEIRO, Antonio Pinto. RTDC: Revista Trimestral de Direito Civil, Rio de Janeiro, v. 30, abr./jun. 2007).
} 
imputável à concepção do produto no qual foi incorporada a parte componente ou às instruções dadas pelos fabricantes do produto." 194

A Diretiva europeia considera o tempo da colocação do produto em circulação para exonerar o fornecedor e não o momento da verificação do dano. Pressupõe-se que o produtor tenha feito a prova da impossibilidade absoluta e objetiva de descobrir o defeito. Vale lembrar que o fator determinante é o mais avançado estado da ciência e da técnica mundial, exigindo efetivo controle de qualidade.

Por outro lado, a Diretiva permitiu que qualquer Estado-Membro possa derrogar essa excludente, mantendo e prevendo em sua legislação que o produtor é responsável, nos termos da letra 'e' do artigo 15:

"Qualquer Estado-membro pode: a) Em derrogação do artigo $2^{\circ}$, prever na sua legislação que, na acepção do artigo $1^{\circ}$, a palavra 'produto' designa igualmente as matérias-primas agrícolas e os produtos da caça; b) Em derrogação da alínea e) do artigo $7^{\circ}$, manter ou, sem prejuízo do procedimento definido no $\mathrm{n}^{\circ} 2$, prever na sua legislação que o produtor é responsável, mesmo se este provar que o estado dos conhecimentos científicos e técnicos no momento da colocação do produto em circulação não lhe permitia detectar a existência do deifeito."

Apesar de ser possível o acolhimento ou não de risco do desenvolvimento como excludente de responsabilidade na Comunidade Europeia, apenas a Finlândia e Luxemburgo não o adotaram como excludente.

A França e a Espanha adotaram a excludente, porém com ressalvas; na Espanha, por exemplo, se excepcionou a excludente do risco do desenvolvimento quanto a determinados produtos, como, no caso, dos remédios e produtos alimentícios.

Jean Calais-Auloy defende a responsabilização do fornecedor e o faz com base em casos concretos ocorridos na França, tais como: medicamento talidomida, amianto, carne da 'vaca louca', do frango com dioxina, do sangue contaminado pelo HIV. O autor critica argumentos econômicos em favor da exoneração da responsabilidade e privilegia argumentos de equidade. ${ }^{195}$

\footnotetext{
${ }^{194}$ Disponível em: <http://europa.eu.int>.

${ }^{195}$ Le risque de dévelopement: une exonération contestable; Mélanges Michel Cabrillac; Paris: Dalloz-Litec, 1999. Apud Revista do Direito do Consumidor, ano 11, n.42, p. 313-316. Apud CHINELLATO, Silmara Juny de Abreu; MORATO, Antonio Carlos. op. cit., p. 46.
} 
Com a vênia devida ao autor supracitado, uma das tendências da responsabilidade civil contemporânea é a condução à coletivização dos riscos. Com efeito, o risco que cada fornecedor tem que arcar é incorporado nos preços, o que acaba por repercutir sobre todos os consumidores.

Ugo Carnevali expressa posição contrária; o autor admite que os riscos do desenvolvimento são riscos inevitáveis da vida, que devem ficar a cargo dos consumidores, elencando diversos fatores; tais como político, pois os fornecedores teriam máxima prudência na fabricação e no lançamento de novos produtos, econômico, que haveria o reflexo no preço dos produtos e duvida que a responsabilização do fornecedor atenderia a fins preventivos. ${ }^{196}$

Enquanto na Europa existe a Diretiva que regula, de certa forma, toda a comunidade europeia, nos Estados Unidos isso não ocorre, porque não há uma única lei que regulamente o assunto.

Nos Estados Unidos a tendência era de responsabilizar o fornecedor pelos danos causados, contudo esse posicionamento foi revertido em razão das seguradoras se recusarem a pagar as indenizações elevadas impostas pelos júris populares. ${ }^{197198}$

Os EUA possuem uma agência responsável pela segurança dos alimentos, medicamentos, cosméticos etc., a Food and Drug Administration (FDA), que faz um trabalho preventivo na análise de possíveis danos aos consumidores. ${ }^{199}$

\footnotetext{
${ }^{196}$ CARVENALI, Ugo. op. cit., p. 230-232.

${ }^{197}$ Marcelo Junqueira Calixto cita o caso de Brown x Abbott Laboratories como precursor desse entendimento. (CALIXTO, Marcelo Junqueira. A responsabilidade civil do fornecedor de produtos pelos riscos do desenvolvimento. Rio de Janeiro: Renovar, 2004. p. 192-195).

${ }^{198}$ Marcelo Junqueira Calixto lembra o caso precursor que mudou o posicionamento nos Estados Unidos: "Precursor desta última orientação foi o caso Brown v. Abbot Laboratories julgado pela Suprema Corte da Califórnia em 31 de março de 1988. Tratava-se de ação movida por mulheres cujas mães utilizaram, na época de sua gravidez, um estrógeno sintético chamado DES, cujo objetivo era evitar abortos involuntários, mas que terminou por provocar tumores vaginais nas autoras. Nesta decisão ficou afastada a aplicação de uma responsabilidade objetiva (strict liability) pois se entendeu que o interesse público caminha no sentido do desenvolvimento e comercialização de novos medicamentos, ainda que possam apresentar sérios riscos, uma vez que estes medicamentos têm o condão de salvar vidas e reduzir a dor e o sofrimento. Além disso, a responsabilidade objetiva poderia ser uma barreira ao progresso científico, uma vez que o fornecedor sofreria o temor de, desenvolvendo novas pesquisas que comprovam os riscos do produto, vir a sofrer graves prejuízos decorrentes de sentenças desfavoráveis. Por fim, asseverou-se que 'tornar responsável um produtor pela falta de advertência sobre um perigo impossível de ser conhecido pelo estado atual do conhecimento humano seria tornar este mesmo produtor (...) segurador virtual do produto.” (Id. Ibid., p. 192).

${ }^{199}$ Através de notícia veiculada no jornal Folha de S. Paulo, em 19 de outubro de 2007, a agência norteamericana lançou novas advertências acerca de possível risco de surdez vinculado ao Viagra e a tratamentos similares contra a impotência sexual.

Os medicamentos Cialis e Levitra tiveram que modificar suas embalagens para alertar sobre esses riscos.
} 
Frise-se que na legislação portuguesa, nos termos do artigo $1^{\circ}$ do Dec-Lei $n^{\circ}$ 383/89, a responsabilidade, muito embora seja objetiva, é relativa, em cujo regime, as regras se sobressaem da exclusão da responsabilidade pelos chamados riscos do desenvolvimento, é dizer, o fornecedor não se responsabiliza pelos defeitos desconhecidos e imprevisíveis no estado da ciência e da técnica contemporâneo à colocação em circulação do produto.

Na Lei $n^{\circ} 16.463$ da Argentina, conhecida como Lei de Medicamentos, há adaptação periódica dos produtos farmacêuticos "de acuerdo con el progresso de la ciencia", excluindo a responsabilidade do fornecedor por riscos de desenvolvimento.

A lei uruguaia embora siga a linha da legislação argentina, é inovadora na previsão do recall dos produtos que tiveram a sua periculosidade detectada após a introdução no mercado. Da mesma forma, é o que prevê a legislação paraguaia, no que concerne ao recall após o conhecimento dos riscos dos produtos colocados no mercado.

A grande dúvida é se no Brasil em razão da omissão de qualquer previsão expressa sobre o assunto, seria possível concluir pela excludente de responsabilidade ou pela responsabilização.

A alocação do risco de desenvolvimento é uma mais difíceis; indiscutivelmente, há uma "viva controvérsia" acerca do assunto. ${ }^{200}$ Marcelo Junqueira Calixto entende que o mais importante seria afirmar a existência do defeito, pois, conclui o autor, que seria pressuposto inafastável da responsabilidade do fornecedor. ${ }^{201}$ Por sua vez, Sergio Cavalieri Filho entende que o risco do desenvolvimento seria risco integrante da atividade do fornecedor, ficaria mais bem alocado como fortuito interno, não admitindo a possibilidade de exoneração de responsabilidade. ${ }^{202}$

Em 26 de dezembro de 2008, foi veiculada notícia sobre a aprovação do governo americano de nova droga para o tratamento de gota, após o comitê consultivo de artrite da FDA ter indicado, por unanimidade, o medicamento com o princípio ativo febuxostat para o controle da hiperuricemia (aumento de ácido úrico no sangue) associada à gota.

${ }^{200}$ Claudia Lima Marques observa que: "Já se disse, com razão, que nesta matéria reina uma viva controvérsia, informada, não raras vezes, de um caráter passional. A pergunta que se faz é a seguinte: "Quem deve arcar com os riscos de alterações tecnológicas que afetem decisões sobre a segurança de produtos? (Thierry Bourgoignie, Eléments, P. 316-318). Ou, em outras palavras: há dever de indenizar quando o dano é causado por bens que, à época de sua produção, estavam de acordo com o estado de conhecimento científico e tecnológico vigente ?" (MARQUES, Claudia Lima; BENJAMIN, Antônio Herman; BESSA, Leonardo Roscoe. op. cit., p. 129).

${ }^{201}$ CALIXTO, Marcelo Junqueira. A responsabilidade civil do fornecedor de produtos pelos riscos do desenvolvimento, cit., p. 212.

${ }^{202}$ CAVALIERI FILHO, Sergio. op. cit., p. 438. 
Por outro lado, Gustavo Tepedino, na defesa de sua tese, entende que se a interpretação for feita a contrario sensu, de alguns artigos pontuais do CDC, concluir-se-ia que os riscos do desenvolvimento seriam uma excludente de responsabilidade. ${ }^{203}$ Nessa linha o artigo 10 pró́be o fornecedor de colocar no mercado produto ou serviço que sabe ou deveria saber apresentar alto grau de nocividade ou periculosidade à saúde ou segurança. Logo, se o fornecedor provar que não tinha conhecimento do alto grau de nocividade ou periculosidade à saúde ou segurança, de acordo com parâmetros universais, justificadamente, seria isento de responsabilização. ${ }^{204}$

Já no inciso III, parágrafo $1^{\circ}$ do artigo 12 , considera-se o produto defeituoso quando não oferece a segurança que dele legitimamente se espera no momento em que foi colocado em circulação.

Com efeito, a responsabilização do fornecedor seria um desestímulo para o desenvolvimento de novos produtos, ou seja, haveria a paralisação do progresso tecnológico. A imprevisibilidade e a impossibilidade de se calcular os danos decorrentes de tais riscos tornaria a carga pesada para o fornecedor e impediria, da mesma forma, a realização de seguro.

Além disso, o fornecedor não pode se tornar um "segurador universal" do próprio produto, ao menos, não isoladamente nos casos em que os produtos apenas foram comercializados, mediante a autorização do Poder Público, dando um caráter de solidariedade do dano. Não que isso implique em uma responsabilidade exclusiva ou em regra do Estado. ${ }^{205}$

Dificilmente a responsabilização do produtor contribuiria para a prevenção de futuros danos, tendo em vista que os defeitos não podiam ser conhecidos à época.

\footnotetext{
${ }^{203}$ TEPEDINO, Gustavo. A responsabilidade por acidentes de consumo na ótica civil-constitucional, cit.

${ }^{204}$ Em sentido contrário, Silmara Juny de Abreu Chinellato e Antônio Carlos Marcato entendem: "Também não é razoável propor a irresponsabilidade quanto a produto que não tenha defeitos verificáveis no momento de sua inserção no mercado (defeitos incognoscíveis), pois a responsabilidade existe, seja o defeito conhecido, seja desconhecido." (CHINELLATO, Silmara Juny de Abreu; MORATO, Antonio Carlos. op. cit., p. 31).

${ }^{205}$ Silmara Juny de Abreu Chinellato e Antonio Carlos Morato advertem: "No nosso modo de ver, não é o Estado quem deve responder, em regra ou com exclusividade, pela assistência às vítimas de dano causado pela iniciativa de um fornecedor privado.

O Estado é composto pelo conjunto de administrados e esquecemos o quanto tal solução lhes é lesiva, pois arcarão com os ônus dessa responsabilidade que é do fornecedor do produto ou serviço do qual resultou o dano. Pretender que a vítima arque com o prejuízo por um hipotético benefício derivado do contínuo aprimoramento técnico e científico - que supostamente seria refreado pela necessidade de indenizar quaisquer danos causados- constituiria um grave retrocesso histórico.” (Id. Ibid., p. 35).
} 
Por outro lado, para os que defendem a responsabilização do fornecedor, seria reintroduzida a noção de culpa, pois o produtor teria que provar que agiu de forma diligente na pesquisa; entretanto, argumento não muito convincente, pois não se está questionando a conduta do produtor, mas os meios empregados. Além disso, os que são favoráveis à responsabilização argumentam que os consumidores seriam, na verdade, cobaias dos produtores.

Em termos de responsabilização, há que se ponderar que os mesmos produtos são feitos por diversos fornecedores, por exemplo, os cigarros são fabricados por diversas empresas e no momento do ajuizamento da demanda a dificuldade se torna presente. Como seria possível ter certeza que o consumidor apenas comprou cigarro da empresa em face da qual se ajuiza a ação.

\subsubsection{Da prescrição da pretensão}

Ainda que alguns autores considerem inviável considerar o risco do desenvolvimento como uma excludente de responsabilidade, há que se limitar a pretensão dos consumidores, caso contrário estar-se-á tornando o fornecedor eternamente responsável por eventual dano que o produto possa acarretar.

Com efeito, o instituto da prescrição limita o exercício do direito; o Código Civil de 2002 estabelece, nos termos do artigo $189^{206}$, que o objeto da ação destruidora da prescrição seria a pretensão, pois desaparece o direito de exigir em juízo a prestação inadimplida.

Maria Helena Diniz define prescrição como fator de extinção da pretensão, ou seja, do poder de exigir uma prestação devida em razão de inércia, na medida em que se deixa escoar o prazo legal. ${ }^{207}$

Nos termos do artigo 27 do Código de Defesa do Consumidor a pretensão da vítima prescreve $\mathrm{e}^{208}$ em 5 (cinco) anos, pelos danos causados por fato do produto ou do

\footnotetext{
${ }^{206}$ Art. 189. Violado o direito, nasce para o titular a pretensão, a qual se extingue, pela prescrição, nos prazos a que aludem os arts. 205 e 206.

O ordenamento jurídico pátrio incorpora a teoria de que a prescrição extingue a pretensão, nos termos do $\S$ 194 do BGB.

${ }^{207}$ DINIZ, Maria Helena. Código Civil comentado. Coordenador até a 5. ed. Ricardo Fiuza., 6. ed. rev. e atual., coordenação de Regina Beatriz Tavares da Silva. São Paulo: Saraiva, 2008. p. 171.

${ }^{208} \mathrm{O}$ prazo previsto no artigo 27 do CDC é prescricional e não decadencial. A título ilustrativo, vale transcrever a seguinte decisão: "Código de Defesa do Consumidor - Responsabilidade pelo fato do produto - Prescrição - A ação de indenização por fato do produto prescreve em cinco anos (arts.12 e 27 do CDC),
} 
serviço, iniciando-se a contagem do prazo a partir do conhecimento do dano e de sua autoria. $^{209}$

O CDC estabelece que o prazo quinquenal começaria a fluir a partir da ocorrência de dois elementos: o conhecimento do dano e de quem seja o seu autor. A dificuldade que se identifica na incidência desta norma é saber quando o consumidor teve efetivo conhecimento do dano. ${ }^{210}$

Para a Diretiva 85/374/CEE, a pretensão dos direitos do lesado se extingue no período de dez anos a contar da data em que o produtor colocou em circulação o produto que causou o dano ${ }^{211}$, critério objetivo que tornaria mais fácil a decretação ou não da extinção da pretensão.

A justificativa para este prazo seria a deterioração do produto com o tempo; além disso, com o passar do tempo as normas de segurança se tornam mais rigorosas e que os conhecimentos científicos e técnicos progridem e, portanto, não seria razoável exigir do produtor uma responsabilidade ilimitada pelos defeitos do seu produto. ${ }^{212}$

Frise-se que o prazo decenal só seria aplicável, evidentemente, para os países que preveem os riscos do desenvolvimento como possíveis de ensejar dever de indenizar.

não se aplicando à hipótese as disposições sobre vício do produto (arts. 18, 20 e 26 do CDC). Recurso conhecido e provido" (STJ, REsp 100.710, rel. Min. Ruy Rosado Aguiar, j. 25.11.1996).

${ }^{209}$ Nesse sentido, o seguinte julgado: "RESPONSABILIDADE POR DANO DECORRENTE DE FATO DO PRODUTO OU SERVIÇO -EXTINÇÃO DO DIREITO DE EXIGIR A REPARAÇÃO - PRAZO QUINQUENAL - INCIDÊNCIA DO ART.27 DO CDC. O direito de exigir a reparação por danos decorrentes de fato do produto ou serviço só se extingue no prazo de cinco anos, contados da data do conhecimento do dano e sua autora, porque subsumido na hipótese do art.27 do CDC. Agravo desprovido. (TJRS - 9a Câm. - Ag.In. 70000587212 - rel. Des. Mara Larsen Chechi - j. 17.05.2000).

${ }^{210}$ Antônio Herman Benjamin adverte que: "O conhecimento do dano tem que ver com a percepção do consumidor de que, efetivamente, sofreu um dano. Não se trata de simples 'manifestação do dano'. Este, é certo, pode já ter se manifestado e, nem por isso, ter sido percebido pela vítima. Imagine-se o caso de um consumidor, contaminado por radiação em alimentos, que, repentinamente, começa a perder cabelo (manifestação do dano), mas que, por falta de orientação médica, atribui tal fato a um problema genético de calvície. A queda do cabelo, aí, por si só, não preenche o requisito do conhecimento do dano. O máximo que se tem, neste caso, é conhecimento dos efeitos do dano, embora carente a percepção de que se trata de dano. E o que o dispositivo quer que é o consumidor tenha consciência de que aquilo que sofre é, de fato, um dano." (BENJAMIN, Antônio Herman. op. cit., p. 138).

${ }^{211}$ João Calvão da Silva ressalva que o dies a quo do prazo decenal é contado da introdução no mercado do produto causador do dano; “ assim, se os produtos de uma série começam a ser postos em circulação em 1 de janeiro de 1990, mas o produto que concretamente causou o dano só foi em 1 de junho do mesmo ano, é este o dies a quo."( SILVA, João Calvão da. Responsabilidade civil do produtor., op.cit., p. 742).

${ }^{212}$ CALIXTO, Marcelo Junqueira. A Responsabilidade civil do Fornecedor de Produtos pelos Riscos do Desenvolvimento., op.cit., p. 169. 


\subsection{Do princípio da legalidade e a liberdade de escolha}

Os homens nascem e permanecem livres ${ }^{213}$ e iguais em direitos, sendo um direito imprescritível e natural do homem, o poder de autodeterminação. A liberdade é direito fundamental que pode ser disciplinado, mas não pode ser cerceado; consubstancia direito que dá cidadania ao indivíduo. ${ }^{214}$

A igualdade e a liberdade transformam os homens nos melhores juízes de seus próprios interesses. Para Rousseau, o único caminho viável para obtenção do fim social é a união da vontade geral com a vontade individual.

Não cabe ao Estado cercear a liberdade, apenas disciplinar a forma desse exercício, sem substituir o ser humano na definição de suas escolhas e da correspondente ação.

Carlos Roberto Siqueira Castro ensina que:

“ Assim, a liberdade, a propriedade, a segurança e a resistência à opressão constituem o âmago das prerrogativas insubtraíveis do indivíduo, cuja tutela e concreção inscreve-se no dever finalístico do ente estatal, não podendo ser funcionalizados, ou seja, colocados a serviço da comunidade política, mas sim deixados permanentemente ao livre e soberano arbítrio de seu titular: o indivíduo."215

Por sua vez, Maria Celina Bodin de Moraes adverte:

\footnotetext{
${ }^{213}$ No clássico O Espírito das Leis, Montesquieu ensina que:“ Num Estado, quer dizer, numa sociedade onde há leis, a liberdade só pode consistir em poder fazer o que se deve querer, e em não ser obrigado a fazer o que não se deve querer.

É preciso ter presente o que é independência e o que é liberdade. A liberdade é o direito de fazer tudo o que as leis permitem. Se um cidadão pudesse fazer o que elas proíbem, ele já não teria liberdade, pois os outros teriam igualmente esse poder." (MONTESQUIEU, Charles de Secondat, Baron de. O espírito das leis: as formas de governo, a federação, a divisão dos poderes. Introdução, tradução e notas de Pedro Vieira Mota. 9. ed. São Paulo: Saraiva, 2008. p. 167.)

${ }^{214}$ Fernanda Pessanha do Amaral Gurgel observa que: "Sob a perspectiva axiológica, vemos que o homem possui a capacidade de apreciar os valores, sejam eles econômicos, éticos, utilitários ou religiosos, e, partindo deles, de autodeterminar-se. Sendo assim, a liberdade é um valor intríneco da natureza humana e por meio dela torna-se possível a definição por outros valores.(...)

Em linhas gerais, trata-se da coexistência harmônica das liberdades individuais, fazendo com que o Estado, mediante suas atividades, desempenhe um papel limitador e regulador, sem, contudo, deixar de respeitar e privilegiar a pura manifestação da vontade como forma de concretização da liberdade filosófica do ser humano." (GURGEL, Fernanda Pessanha do Amaral. Função do direito privado no atual momento histórico. In: NERY, Rosa Maria; DONINI, Rogério (Coords.). Responsabilidade civil: estudos em homenagem ao professor Rui Geraldo Camargo Viana. São Paulo: Ed. Revista dos Tribunais, 2009. p. 11).

${ }^{215}$ CASTRO, Carlos Roberto Siqueira. Função normativa regulatória e o novo princípio da legalidade: o poder normativo das agências reguladoras. Rio de Janeiro: Forense, 2006. p. 29.
} 
"O problema maior do Direito na atualidade tem sido exatamente o de estabelecer um compromisso aceitável entre os valores fundamentais comuns, capazes de fornecer os enquadramentos éticos nos quais as leis se inspirem, e espaços de liberdade, os mais amplos possíveis, de modo a permitir a cada um a escolha de seus atos e o direcionamento de sua vida particular, de sua trajetória individual." 216

É ao próprio indivíduo que cabe a decisão quanto às formas do exercício de seu direito de liberdade, que encontra limitações pelas próprias fronteiras nacionais de outros indivíduos, ou seja, a liberdade de um controla a liberdade de outrem. ${ }^{217}$

O homem tem condições de formar opiniões sobre determinado estado de coisas, como o caso de optar ou não pelo bronzeamento artificial ou por fumar ou não fumar. Nesse sentido, Tereza Ancona Lopez ressalva que:

" a liberdade de fumar é um direito humano tanto quanto a liberdade de não fumar. Ninguém é obrigado a fazer alguma coisa ou deixar de fazêla. O Estado deve proteger e harmonizar essas duas liberdades antagônicas. Os limites aos exercícios das liberdades, de todos os tipos, podem e devem ser estabelecidos pelo Estado para a boa convivência social. Diferente disso é suprimir a liberdade de uns em privilégio de outros, afrontando o princípio da isonomia, porquanto os direitos dos cidadãos podem ser antinômicos, mas são sempre simétricos." 218

${ }^{216}$ MORAES, Maria Celina Bodin de. Princípios de direito civil contemporâneo. Rio de Janeiro: Renovar, 2003, p. 71.

${ }^{217}$ Recentemente a Anvisa proibiu em todo o país bronzeamento artificial em clínicas estéticas, inclusive a atitude foi alvo de protesto de mulheres nas ruas de Porto Alegre (RS), as quais, se sentiram prejudicadas com a proibição. A decisão foi tomada com base em estudos que apontaram os efeitos nocivos dessa prática. Pesquisas científicas comprovaram que a emissão de raios ultravioleta aumenta os riscos de câncer de pele, o que foi objeto de consulta pública para que os profissionais de saúde, fabricantes e a própria população opinar sobre o assunto. Esse tipo de bronzeamento já estava proibido pela Anvisa para menores de 16 anos e para jovens com idade entre 16 e 18 anos que não apresentassem autorização do responsável legal. (<http://noticias.terra.com.br/brasil/noticias>. Acesso em: 11 nov. 2009).

${ }^{218}$ LOPEZ, Teresa Ancona. op. cit., p. 16.

De outra forma entendeu o TJ/RS, ao condenar a empresa de cigarro ao pagamento de dano moral, no valor de 500 salários mínimos para a viúva e para cada um dos filhos a quantia de 300 salários mínimos, no seguinte recurso: “(...) As regras de experiência, enfim, demonstram que o exame do nexo causal pode ser ampliado pelo que se tem conhecimento da vida, relativamente ao uso do cigarro, o mal que tem causado aos seus usuários e que estão a nos rodear, trazendo consequências maléficas irreversíveis em muitos casos. Tudo pelo uso inadequado dos dependentes químicos e psíquicos, sem que haja qualquer responsabilização das indústrias fabricantes de cigarros, que apenas lucram com o seu agir e em nada contribuem para amenizar o mal que causam à saúde pública deste País. (...) Por outro lado, não se discute da licitude ou não do agir da empresa que fabrica o cigarro, pois se sabe que está a agir com a conivência da Federação e do Estado, que se beneficiam com o retorno dos impostos." (Apelação Cível no 70007090798, 9ª Câmara, 19.11.2003).

Questionável o entendimento da $9^{\text {a }}$ Câmara do TJ/RS, ainda que o cigarro tenha causado a doença, a vítima tinha pleno conhecimento dos malefícios do fumo e mesmo assim optou por mantê-lo, durante trinta anos. Se todos os fumantes ajuizarem a mesma demanda e tiverem o mesmo êxito, as empresas de cigarro entrarão em falência,; não se pode esquecer que é uma atividade lícita, pois o próprio Estado permite a comercialização do produto.

Vale transcrever trecho de outro julgado que serviu como precedente: "Ainda que se considere que a propaganda e a dependência não anulem a vontade, o fato é que a voluntariedade no uso e a licitude da 
De fato, o respeito à liberdade é direito fundamental previsto no inciso II do artigo $5^{\circ}$ da Constituição Federal que pode ser disciplinado, mas não pode ser cerceado. A liberdade é direito que dá cidadania ao indivíduo. Sem dúvida, o homem é senhor de sua consciência; ao Estado cabe apenas disciplinar a forma desse exercício, sem substituir o ser humano na definição de suas escolhas e da correspondente ação.

$\mathrm{Na}$ hipótese de o fumante ficar doente por causa do seu vício, será o único responsável, porque assumiu o risco e o nexo de causalidade não restou configurado, especialmente, nos dias atuais, em que as empresas são obrigadas a informar sobre os malefícios do fumo.

Gustavo Tepedino retrata uma multifatoriedade da cadeia causal na questão do tabagismo, pois o hábito de fumar, a poluição urbana, a fumaça da lenha do campo, os hábitos alimentares, a qualidade de vida e outros fatores de risco conhecidos ou ainda desconhecidos, bem como as condições (ou cargas) genéticas, constituem-se em causas prováveis da doença (isto é, probabilidade estatística). E adiante complementa que somente pode-se considerar como causa jurídica de um evento danoso o comportamento ou atividade ligada ao dano pelo nexo de causalidade necessário. ${ }^{219}$

A lei é, de fato, expressão da vontade geral, só podendo ser abolida por outra lei. ${ }^{220}$ Com efeito, ninguém pode ser constrangido a fazer o que a lei não ordena. No quadro atual do ordenamento jurídico brasileiro, não pode ser descartado o papel da vontade do particular; de fato, na responsabilidade civil, há espaço para a autonomia, sob pena de se tornar puro paternalismo estatal.

Há que se reconhecer que inúmeros produtos comercializados, hoje em dia, que não é possível comprovar se o seu uso acarretará ou não, algum dano, seriam "abolidos" pelos consumidores de suas vidas, tendo em vista a utilidade que proporcionam, no caso,

\footnotetext{
atividade da indústria não afastam o dever de indenizar. Desimporta a licitude da atividade perante as leis do Estado e é irrelevante a dependência ou voluntariedade no uso ou consumo para afastar a responsabilidade. A licitude da atividade e o uso ou consumo voluntário não podem levar à impunidade do fabricante ou comerciante de produto que causa malefícios às pessoas, inclusive a morte. Sempre que um produto ou bem -seja alimentício, seja medicamento, seja agrotóxico, seja à base de álcool, seja transgênico, seja o próprio cigarro - acarrete mal às pessoas, quem o fabricou ou colocou no mercado responde pelos prejuízos decorrentes." (Apelação Cível n 70000144626, Rel Des. Cassiano).

${ }^{219}$ TEPEDINO, Gustavo. Temas de direito civil. Rio de Janeiro: Renovar, 2009. t. 3, p. 386-387.

${ }^{220}$ Kant ensina que: "A consciência da necessidade de uma livre submissão da vontade à lei é consenso racional, consenso que perpetua uma violência inevitável que é preciso exercer sobre todas as inclinações, violência essa deve ser exercida unicamente mediante o ditame da própria razão, constitui o respeito à lei." (HORVATH JÚNIOR, Miguel. Uma análise da autonomia privada e o fenômeno da globalização e seus efeitos no direito constitucional e no direito internacional privado. In: LOTUFO, Renan (Coord.). Direito civil constitucional: cadernos 1. São Paulo: Max Limonad, 1999. p. 15.
} 
por exemplo, da confirmação dos malefícios do uso dos celulares, dos computadores, o consumo de refrigerantes ou até mesmo no caso de optar ou não pelo bronzeamento artificial, a proibição da Anvisa de clínicas estéticas viola a liberdade do homem.

Sem dúvida, deve prevalecer a liberdade de escolha de cada indivíduo para que o Estado não subestime seus cidadãos superprotegendo-os; o consumidor deve ser responsável pelas suas escolhas, no momento da aquisição de determinado produto, pois aquele tem plenas condições de formar opiniões sobre determinado estado de coisas.

Dessa forma, o Estado não pode criar uma sociedade de eternas crianças, ser adulto não significa acertar sempre, mas pressupõe tomar conscientemente as decisões que importam sobre a própria vida. ${ }^{221}$

\subsection{Do princípio da precaução}

Muito embora os riscos não possam ser eliminados, é certo que eles podem ser maiores ou menores. A prevenção seria toda e qualquer medida destinada a evitar os prejuízos causados por atividade conhecidamente perigosa, enquanto que precaução seria a incerteza sobre a periculosidade, evitar ou controlar risco meramente potencial. ${ }^{222223}$

Diante da necessidade da criação de outros instrumentos que sejam distintos da responsabilidade civil, a aplicação do princípio da precaução por meio de deveres de comportamentos prévios se impõe a aplicação. A ideia é que não apenas a lesão, em si mesma, deve ser evitada, como a própria potencialidade da lesão.

Deve-se aplicar o princípio $^{224}$ da precaução em virtude da impossibilidade de excluir totalmente os riscos da sociedade. Em matéria ambiental, por exemplo, é possível identificá-lo no artigo 225 da Constituição Federal e na Lei de Biossegurança, Lei no $11.105 / 2005$.

\footnotetext{
${ }^{221}$ LOPEZ, Teresa Ancona. op. cit., p. 17.

${ }^{222} \mathrm{E}$ importante mencionar o risk management técnica que identificaria pontos de risco em cada estrutura organizacional e eliminá-los antes da produção de danos.

${ }^{223}$ SCHREIBER, Anderson. Novos paradigmas da responsabilidade civil: da erosão dos filtros da reparação à diluição dos danos. São Paulo: Atlas, 2007. p. 220.

${ }^{224}$ Miguel Reale ensina que: "toda forma de conhecimento científico implica a existência de princípios, isto é, certos enunciados lógicos admitidos como condição ou base de validade das demais asserções que compõem um dado campo do saber." (REALE, Miguel. Lições preliminares de direito. 22. ed. São Paulo: Saraiva, 1995. p. 299).

Os princípios formam as ideias diretivas e o espírito, muito embora, não estejam expressos, mas são pressupostos pela ordem jurídica.
} 
O princípio da precaução age no presente a fim de reduzir os riscos, a um nível mínimo, ou seja, aceitável.

Paralelamente, no tocante à reparação dos danos já ocorridos, a tendência é a prevenção e a precaução; certo de que determinada atividade implicará dano injusto, está forçado a evitá-lo o responsável pela atividade perigosa; ou até mesmo o Estado Democrático tem o dever de agir preventivamente, com instituição de deveres de comportamentos prévios. $^{225}$

Em geral, existem diversos procedimentos de avaliação de segurança, no campo alimentar, por exemplo, com intuito de obter harmonização de princípios de precaução. $\mathrm{O}$ objetivo é a melhoria na qualidade de qualquer tipo de alimento.

Existem sistemas de qualidade em alimentos denominados de Boas Práticas de Fabricação (BPF) e a Análise de Perigos e Pontos Críticos de Controle (APPCC), em inglês são GMP Good Mannufacturing Practices e HACCP Harzard Analysis and Critical Control Points.

O sistema APPCC objetiva a prevenção, monitoramento e combate às causas de enfermidades ou danos à saúde humana, de origem biológica, química ou física.

A importância da aplicação do princípio da precaução para evitar danos causados pelo risco do desenvolvimento é indiscutível. ${ }^{226} \mathrm{O}$ inciso $\mathrm{V}$ do artigo 4 do CDC prevê que os fornecedores criem meios eficientes de controle de qualidade e segurança de produtos e serviços, assim como de mecanismos alternativos de solução de conflitos de consumo.

Talvez seja possível evitar muitos transtornos, por meio de departamentos de pesquisas de tecnologia de ponta nas empresas, principalmente, no caso de farmacêuticas,

\footnotetext{
${ }^{225}$ Cabe citar Juarez Freitas: "Como quer que seja, se houver certeza suficiente de que determinado prejuízo acontecerá, a rede de causalidade precisa ser tempestivamente interrompida.(...)

Em outras palavras, na prevenção, antevê-se, com segurança, o resultado maléfico e, correspondentemente, nos limites das atribuições normativas, surge a obrigação de o Estado tomar as medidas interruptivas da rede causal, de molde a evitar o dano antevisto. Para ilustrar, trata-se de iniludível dever de prevenção (não de precaução) o combate a futuros danos trazidos pela prática do tabagismo em lugares como aviões, uma vez que tais malefícios são sobejamente conhecidos." (MERLIN, Clèmerson; SARLET, Ingo Wolfgang; PAGLIARINI, Alexandre Coutinho (Coords). Direitos humanos e democracia. Rio de Janeiro: Forense, 2007. p. 373).

Adiante o autor elucida: "Viável, assim, a outorga da tutela específica para que o Poder Público tome as providências obrigatórias de caráter preventivo.” (op. cit., p. 373).

${ }^{226}$ José Geraldo Brito Filomeno elucida que: "O incentivo à criação pelos fornecedores de meios eficientes de controle de qualidade e segurança de produtos e serviços, objeto da primeira parte do inciso $\mathrm{V}$ do art. $4^{\circ} \mathrm{em}$ pauta, refere-se à preocupação cada vez mais evidenciada, junto aos próprios produtores/fornecedores de produtos e serviços, no sentido de se amoldarem aos padrões de qualidade já referidos, ainda que sem caráter compulsório, o que certamente lhe aumentará o prestígio junto aos consumidores." (FILOMENO, José Geraldo Brito. op. cit., p. 15).
} 
de forma direta; e, de forma indireta, pelo órgão estatal ${ }^{227}$, que atue de forma efetiva na análise dos produtos que serão comercializados.

\subsection{Do desenvolvimento científico e tecnológico}

O risco do desenvolvimento está intimamente ligado à ciência e tecnologia, pois o incentivo à pesquisa proporciona mais segurança aos produtos inseridos no mercado.

Na Constituição Federal de 1988 foi dedicado um capítulo especial sobre a Ciência e a Tecnologia, de modo a garantir que o maior número de pessoas se beneficie dos recursos do progresso. ${ }^{228}$

Caio Tácito pondera que:

" Se, de uma parte, a sociedade de consumo, assim estimulada, leva à psicologia do supérfluo, ou à contaminação do meio ambiente, de outra parte, os benefícios da ciência conquistam para o homem um novo estágio de bem-estar, prolongam a duração da vida e desvendam mistérios da natureza.

A este mundo novo, a Constituição de 1988 abre caminho afirmando o valor da ciência pura e aplicada, atribuindo à pesquisa científica o tratamento prioritário do Estado, visando o bem público e o progresso do conhecimento.

A formação de recursos humanos nas áreas de ciência, pesquisa e tecnologia deverá merecer apoio do Estado, com estímulo à contribuição das empresas, destacando-se a importância de financiamento público às atividades universitárias de pesquisa e de extensão.

A destinação da pesquisa tecnológica deverá ter como finalidade preponderante a solução dos problemas brasileiros e o desenvolvimento do sistema produtivo nacional e regional." 229

\footnotetext{
${ }^{227}$ Anderson Schreiber observa: "Em algumas áreas, especialmente as vinculadas à prestação de serviços públicos, o modelo das agências reguladoras tem sido adotado de forma a combinar o interesse na prestação da atividade com a proteção dos interesses da coletividade beneficiária daquele serviço. No Brasil, a Agência Nacional de Telecomunicações (Anatel) e a Agência Nacional de Energia Elétrica (Aneel) têm imposto significativas medidas destinadas a evitar a produção de danos aos consumidores de modo geral, e já gozam de uma consolidada reputação neste sentido órgãos fiscalizadores do mercado, como o Conselho Administrativo de Defesa Econômica (Cade) e a Comissão de Valores Mobiliários (CVM)." (SCHREIBER, Anderson. op. cit., p. 221).

${ }^{228}$ Alexandre de Moraes observa que: "Compete, constitucionalmente, ao Estado promover e incentivar o desenvolvimento científico, a pesquisa e a capacitação tecnológicas (CF, art.218), sendo, inclusive, facultado aos Estados e ao Distrito Federal vincular parcela de sua receita orçamentária a entidades públicas de fomento ao ensino e à pesquisa científica e tecnológica." (MORAES, Alexandre. Direito constitucional. 15. ed. São Paulo: Altas, 2004. p. 698).

${ }^{229}$ TÁCITO, Caio. Temas de direito público: (estudos e pareceres). Rio de Janeiro: Renovar, 1997. p. 473474.
} 
Entretanto, constata-se, atualmente, a dificuldade de dominar os efeitos da tecnologia, em suas mais amplas dimensões. No campo da pesquisa genética, as empresas gastam imensos recursos, muitas vezes, durante um longo período, sem, em contrapartida, garantia de sucesso.

A área farmacêutica é, sem dúvida, a mais crítica, na medida em que vultosas quantias são mobilizadas para a obtenção de incerto resultado, cujo intuito consiste em beneficiar a sociedade. É importante lembrar que os medicamentos não produzem a mesma reação, em todos os indivíduos, podendo variar de acordo com cada organismo. Algumas mulheres, por exemplo, tem predisposição a câncer de mama, por razão genética; outras pessoas têm mais chances de ter diabetes do que outras etc.

De fato, o conhecimento de quais projetos se deve ou não empreender representa, na maioria das vezes, o sucesso ou o fracasso de uma empresa de biotecnologia, por exemplo. $^{230}$

No tocante ao risco do desenvolvimento, para que a excludente de responsabilidade seja adotada o 'produtor ideal' deve, invariavelmente, estar atento às tecnologias de ponta, sendo injustificável a falta de condição econômica para não ser responsabilizado.

Por outro lado, Maria Celina Bodin de Moraes adverte para a 'explosão de ignorância', na medida em que crescem os horizontes do saber, mas na mesma proporção, crescem, as questões sem solução, do desconhecimento.

\footnotetext{
${ }^{230}$ Bill Gates explica que: "Saber quais projetos não se deve empreender pode representar o sucesso ou o fracasso de uma empresa de biotecnologia. A informação digital ajuda a eliminar os custos enormes de pesquisas desnecessárias e melhorar a tomada de decisões nos estágios iniciais - um efeito importante, pois cada passo sucessivo em $P \& D$ e produção tende a ser mais caro que o anterior. Os sistemas digitais permitem que a empresa de biotecnologia jogue os dados com mais freqüência, e mais apostas equivalem a uma chance maior de fazer descobertas médicas. Com uma troca melhor de informações entre os cientistas sobre coisas tais como toxicidade inerente de compostos, a freqüência de acertos a cada rolar dos dados também aumentará. As empresas de biotecnologia precisam aperfeiçoar a qualidade dos candidatos a produto cada trilho, e se um deles quebrar, é preciso tirá-lo do caminho o mais rápido possível para que outro candidato passe.." (GATES, Bill. A empresa na velocidade do pensamento: com um sistema nervoso digital. Tradução Pedro Maia Soares, Gabriel Tranjan Neto; assessoria técnica Sylvia Meraviglia Crivelli. São Paulo: Companhia das Letras, 1999. p. 260). Adiante acrescenta que: "Ferramentas digitais estão garantindo um avanço exponencial na busca da cura do câncer, identificando e individualizando genes que causam a maior parte dos tumores.

As ferramentas digitais também ajudam os cientistas a descobrir compostos que reagem quimicamente com genes específicos e a testar aqueles que combatem a toxicidade, encurtando rapidamente a busca de eficazes agentes de combate ao câncer. Um grande laboratório farmacêutico, que testava 50 mil compostos por ano em 1993 e mais de 50 mil por mês em 1998, espera atingir os 50 mil por dia em 2003." (Id. Ibid., p. 260).
} 
Nas palavras da autora:

"Com facilidade, substituem-se os 'resultados seguros' de uma investigação por mais uma eventualidade, uma possibilidade ou um ponto de vista. Logo, já não haverá tempo hábil para transformar a enorme massa de dados que já se encontram à disposição em conhecimento e, portanto, em informações passíveis de dominação ou de certeza.

A vocação técnica do conhecimento cientifico, se, por um lado, garantiu a sobrevivência do ser humano em níveis nunca antes alcançados - tanto em quantidade como em qualidade - , por outro lado, permitindo sua construção sem a colaboração de outros saberes, fez com que aprendêssemos a 'sobreviver no mesmo processo e medida em que deixamos de saber viver. Um conhecimento anônimo que reduziu a práxis a técnica. De outro lado, a hibridação entre ciência e tecnologia havendo cada vez menos espaço para a divisão entre ciência, como pura produção de conhecimentos, e técnica, como aplicação desses conhecimentos - fez com que fosse alterada a relação 'saber-poder'.,"231

Ao mesmo tempo em que a sociedade exige segurança, percebe-se que a falta de informação instala, algumas vezes, o medo e a resistência a determinados produtos, é o caso, por exemplo, dos alimentos transgênicos. Sem dúvida, toda inovação conduz a uma resistência ao uso em virtude da dúvida na segurança que o produto proporcionará. ${ }^{232}$

João Geraldo do Brito Filomeno ilustra:

"Consoante dão conta, porém, documentos obtidos junto à Consumers International (CI), via Instituto Brasileiro de Defesa do Consumidor (Idec), uma das maiores preocupações dos consumeristas, neste início de um novo século, diz respeito aos alimentos. Mas isso não apenas quanto a sua escassez, como também, e por isso mesmo, quanto às modificações genéticas que têm sido operadas em sua produção, Outra grande preocupação concerne às modificações ambientais em face dessa biodiversidade artificial, já que o ecossistema estará certamente recebendo novas espécies e, por conseguinte, estão-se estabelecendo novas cadeias biológicas de sobrevivência e de multiplicação de espécies naturais.

Referida preocupação, no âmbito dos alimentos, refere-se não apenas ao estabelecimento de um código a eles relativo e praticamente universal (codez alimentarius), já que em decorrência da globalização cresccente da economia todos os seres humanos estão sujeitos ao consumo de

\footnotetext{
${ }^{231}$ MORAES, Maria Celina Bodin de. Danos à pessoa humana: uma leitura civil-constitucional dos danos morais. Rio de Janeiro: Renovar, 2003. p. 61-62.

${ }^{232}$ Flavio Finardi Filho e Regina Sorrentino Minazzi Rodrigues explicam que: "De modo semelhante ao que ocorreu com a Revolução Verde, que inovou os procedimentos agrícolas e trouxe incertezas quanto à inocuidade dos insumos empregados na lavoura, a tecnologia do DNA recombinante (rDNA) também suscita desconfiança sobre a segurança em consumi-los diariamente. Afinal, esta tecnologia quebrou a barreira natural, que limitava o cruzamento apenas entre indíviduos da mesma espécie até de seres de reinos diferentes, como os de bactérias em plantas e os de animais em microrganismos. Paralelamente possibilita a reintrodução de um gene no tecido de origem após modificação ou mutação in vitro.”(op. cit., p. 248).
} 
produtos alimentícios variados e de diversas origens. Mas também principalmente no que diz respeito aos alimentos geneticamente modificados.

Com efeito, consoante dá conta o estudo acima referido, mediante anexo produzido por Michael Hansen, para o Instituto de Política Consumerista da Associação de Consumidores dos Estados Unidos ("Saúde e Segurança Relativas aos Alimentos Geneticamente Manipulados"), em apertada síntese, referidas modificações genéticas, quer com o fito de aumentar a produtividade, quer aprimorando os valores nutritivos ou qualquer outra razão que se possa aduzir, acarretam, ao mesmo tempo, graves riscos aos consumidores difusamente considerados." ${ }^{233}$

Com efeito, os dados estatísticos sobre o crescimento populacional e, ao mesmo tempo, a fome no mundo, são preocupantes. A expectativa é que a população atinja sete bilhões nos próximos anos. A fome atinge milhares de pessoas impedindo o desenvolvimento físico e mental de diversas crianças. Diante desse cenário está o desafio da utilização dos alimentos geneticamente modificados. ${ }^{234}$

A CTNBio, integrante do Ministério da Ciência e Tecnologia, exerce função imprescindível no processo técnico e científico nas áreas de biossegurança, biotecnologia, bioética e afins, ou seja, depende da análise desse órgão a avaliação e monitoramento de eventual risco de OGM e seus derivados. De fato, a análise deve ser feita caso a caso.

Vale mencionar que a lei de biossegurança visa proteger a ciência voltada para o controle e minimização de riscos decorrentes da prática de certas tecnologias; o fim precípuo é proteger a saúde humana e, sem dúvida, o meio ambiente como um todo, por meio do avanço dos processos tecnológicos.

É válido transcrever o artigo $1^{\circ}$ da Lei 11.105 de 2005 :

“ Art. $1^{\circ}$ Esta Lei estabelece normas de segurança e mecanismos de fiscalização sobre a construção, o cultivo, a produção, a manipulação, o transporte, a transferência, a importação, a exportação, o armazenamento, a pesquisa, a comercialização, o consumo, a liberação no meio ambiente e o descarte de mecanismos de organismos geneticamente modificados - OGM e seus derivados, tendo como diretrizes o estímulo ao avanço científico na área de biossegurança e biotecnologia, a proteção à vida e a saúde humana, animal e vegetal, e a

\footnotetext{
${ }^{233}$ FILOMENO, José Geraldo Brito. op. cit., p. 94.

${ }^{234}$ José Alcebíades de Oliveira Junior acrescenta que: “O melhoramento de plantas e, portanto, de alimentos a fim de resolver esses problemas é milenar. Técnicas tradicionais de cruzamento, envolvendo transferências de genes e alteração de cromossomos, produziram muitos resultados importantes, embora também muitas surpresas, como a geração de sementes não-férteis." (OLIVEIRA JUNIOR, José Alcebíades de. Direito ambiental e direito do consumidor: polêmica dos transgênicos. Revista de Direito do Consumidor, São Paulo, ano 17, n. 66, p. 37, abr./jun. 2008).
} 
observância do princípio da precaução para a proteção do meio ambiente."

Indiscutivelmente, a lei de biossegurança é polêmica, nesse sentido, em razão dos efeitos dos alimentos geneticamente modificados serem desconhecidos. $\mathrm{O}$ desconhecimento dos efeitos dos alimentos geneticamente modificados leva muitos cientistas e ambientalistas a criticarem a sua utilização, pois, não haveria possibilidade de impedir a possível ocorrência de eventuais efeitos maléficos. Entretanto, ao mesmo tempo, percebe-se a necessidade de se encontrar alternativas para combater a fome. ${ }^{235}$

\subsection{Da distribuição dos prejuízos}

\subsubsection{Dos seguros}

Cabe a distribuição dos prejuízos tendo em vista que, embora não se possa, isoladamente, responsabilizar o fabricante/produtor, pelas considerações já expedidas, a vítima não pode restar irresarcida.

Assim, impõe-se cogitar de mecanismos e os seguros são um deles, aptos a socializar os prejuízos decorrentes da inserção de produtos, cujos riscos são desconhecidos.

A formatação inicial do seguro esteve ligada à cooperação mútua e ao trabalho da família. Os mesmos elementos de cooperação mútua, advindos do seio familiar, foram aplicados na atividade mercantil; diante de pactos sucessivos todos contribuíam para um fundo comum com ajuda financeira ou prestavam sua colaboração em serviços de assistência aos necessitados para beneficiar a vítima do dano. ${ }^{236}$

\footnotetext{
${ }^{235}$ A fim de satisfazer necessidades humanas tem se buscado novo modelo de desenvolvimento rural, Flavia Trentini pondera: "O novo modelo de desenvolvimento rural procura integrar os povos através de uma agricultura sustentável e competitiva. A Food Agriculture Organization (FAO) conceitua agricultura sustentável como 'o manejo e a conservação dos recursos naturais e a orientação de mudanças tecnológicas e institucionais de tal maneira a assegurar a satisfação de necessidades humanas de forma continuada para as gerações presentes e futuras. Tal desenvolvimento sustentável conserva o solo, a água, e recursos genéticos animais e vegetais: não degrada o meio ambiente: é tecnicamente apropriado, economicamente viável e socialmente aceitável." (TRENTINI, Flávia. Fauna, políticas públicas e instrumentos legais = Wildlife protection: policy and legal instruments. Organizado por Antonio Herman Benjamin. São Paulo: Instituto O Direito por um Planeta Verde, 2004. p. 345).

${ }^{236}$ Pedro Alvim comenta que: "Os laços de consaguinidade e a afinidade de sentimentos mantinham viva a solidariedade do grupo na busca do interesse comum de abrigo, de alimentos e de defesa, conferindo a essa instituição social o papel relevante que sempre desfrutou e que ainda conserva em nossos dias." (ALVIM, Pedro. O contrato de seguro. 3. ed. Rio de Janeiro: Forense, 2001. p. 2-3).
} 
Com efeito, a pulverização dos riscos é inevitável ${ }^{237}$, caso contrário, o ônus será imputado a apenas um fornecedor ou uma empresa. As companhias seguradoras estão diretamente envolvidas na função de repartição, ainda que, inicialmente, a responsabilidade civil e a securitização fossem interpretados como instrumentos incompatíveis.

O seguro encontra sua razão de existir no fato da impossibilidade de existência estritamente individual da sobrevivência do homem; há, incontestavelmente, a dependência de sua inserção num grupo social que o protege e cujos membros defendem uns aos outros. Tem sido frequente a utilização do seguro de responsabilidade civil, por meio da assunção econômica feita pelo segurado, para que não comprometa a sua própria empresa.

O Código Civil brasileiro no artigo $787^{238}$ prevê que, no seguro de responsabilidade civil, o segurador garante o pagamento de perdas e danos devidos pelo segurado a terceiro. Muito embora o caput tenha previsto esta possibilidade, o $\S 4^{\circ}$ do dispositivo não elide a responsabilidade do segurado no caso do segurador ser insolvente.

A tendência da responsabilidade civil contemporânea é a coletivização dos riscos, pois, sem dúvida, a sociedade atual é muito complexa e muito exigente, para que apenas um fornecedor seja responsável por eventual produto colocado no mercado no momento em que o defeito era totalmente desconhecido.

Indiscutivelmente, os seguros, atualmente, são uma forma de garantia de reparação civil, demonstrando o anseio pela repartição dos danos pelos agentes potencialmente lesivos.

\footnotetext{
${ }^{237}$ Ivan de Oliveira Silva adverte: “ Para que a atividade securitária subsista é imprescindível que os riscos sejam fracionados entre uma multiplicidade de pessoas capazes de suportar o evento. Sem a pulverização dos riscos a atividade securitária se tornaria inevitavelmente inviável.

Não basta, pois, a reunião de pessoas com propósitos essencialmente comuns, mas é necessário que tais pessoas vinculem-se pelos vícios próprios e alheios para que o mercado de seguros tenha perspectivas economicamente viáveis." (Curso de direito do seguro / Ivan de Oliveira Silva. - São Paulo: Saraiva, 2008, P. 21-22)

Em outra oportunidade o mesmo autor elucida que: "Ora, neste ponto é importante destacar que a mola propulsora do seguro, embora fundada na cooperação mútua, não era somente a intenção de ajuda à vítima do sinistro, mas, num segundo momento (e talvez o mais importante), consubstanciava-se no receio do eventual dano, haja vista que aquele que não compactuasse com o fundo comum, assumiria o risco da viagem sozinho.

Destacava-se, portanto, uma marcante motivação pautada na precaução. Diante disso, é possível ainda afirmar que a mola propulsora dos antigos pactos securitários, fundados no mutualismo, representava o intenso desejo de o sujeito prevenir-se de eventuais prejuízos futuros e incertos." (op. cit., p. 7).

${ }^{238}$ Art.787 No seguro de responsabilidade civil, o segurador garante o pagamento de perdas e danos pelo segurado a terceiro.

$\S 4^{\circ}$ Subsistirá a responsabilidade do segurado perante o terceiro, se o segurador for insolvente.
} 
Por intermédio do contrato de seguro, o segurador se obriga, mediante o pagamento do prêmio $^{239}$, a garantir interesse legítimo do segurado, contra riscos predeterminados de certa atividade. ${ }^{240}$

Entretanto, o risco do desenvolvimento é difícil de ser mensurado para efeitos de ser segurado, incontestavelmente, as condições seriam, por demais onerosas o que, inevitavelmente, causaria não apenas o desemprego de empregados do setor, como até mesmo, em algumas hipóteses, a própria falência da empresa. Além disso, todos os consumidores também arcarão com o prejuízo, pois o custo dos produtos, certamente, aumentará.

De fato, a essência da responsabilidade civil é imputar a responsabilidade ao agente do dano e não transferir o dever de reparar para terceiro. Entretanto, ainda que essa transferência seja contraditória, a evolução da responsabilidade civil caminhou nesse sentido, justamente com o objetivo de assegurar a integral reparação às vítimas.

Os seguros de responsabilidade civil são feitos com base nos critérios da homogeneidade e da freqüência. ${ }^{241} \mathrm{E}$ tem por objetivo a diluição dos danos, ao repartir entre os custos advindos da indenização de determinado dano, por meio da cobrança de prêmios.

\footnotetext{
${ }^{239}$ Anderson Schreiber comenta que: “ pelo segurador das obrigações derivadas da sua eventual responsabilização no exercício de certa atividade. Tal difusão tende a alcançar a totalidade dos casos em atividades fortemente oneradas pela aplicação da responsabilidade civil, como ocorre, nos Estados Unidos, com a prática médica onde o aumento do valor das indenizações em virtude dos punitive damages estimulou, apenas entre 2000 e 2002, um aumento de $15 \%$ no valor dos prêmios pagos por médicos em geral, com elevação ainda maior para certas especialidades, como ginecologistas (22\%) e cirurgiões gerais (33\%)." (SCHREIBER, Anderson. Novas tendências da responsabilidade civil brasileira, cit., p. 219).

O supracitado autor completa que em algumas legislações inclusive há vedação dessa transferência de responsabilidade: "Em alguns ordenamentos, os seguros de responsabilidade civil são expressamente regulados, inclusive com a vedação à transferência do ônus econômico de certos danos. Na Itália, por exemplo, o Código Civil regula a 'assicurazione della responsabilità civile', e exclui expressamente da incidência destes contratos os danos dolosamente causados pelo segurado, cujo ônus não pode, por questões de política legislativa, ser transferido à companhia seguradora.

De fato, o desenvolvimento dos seguros de responsabilidade evidencia uma busca espontânea dos agentes potencialmente lesivos e, em última análise, de toda a sociedade / por uma repartição de riscos, com a distribuição entre si dos danos advindos da sua atividade primordial. Em paralelo, portanto, às ações de indenização, a iniciativa privada desenvolve um mecanismo que altera, profundamente, os resultados alcançados com a reparação dos danos. Com efeito, a responsabilidade civil, essencialmente a responsabilidade subjetiva, sempre foi entendida como uma técnica de transferência do dano (loss-shifting), sendo a perda transferida da vítima para um agente tido como responsável, por ter agido culposa ou dolosamente. $\mathrm{O}$ advento dos seguros de responsabilidade civil, mesmo nos casos de responsabilização por culpa, altera o resultado final da responsabilização que, abstraindo inteiramente todos os esforços judiciais no sentido de se identificar 'culpado' ou 'causador', deixa de transferir ao réu o dano, para difundi-lo entre diversos potenciais responsáveis (loss-spreading)." (SCHREIBER, Anderson. Novas tendências da responsabilidade civil brasileira, cit., p. 219-220).

${ }^{240}$ DIAS, José de Aguiar. op. cit., p. 1124.

${ }^{241}$ ARAÚJO, Maria Angélica Benetti. op. cit.
} 
Aspecto preocupante é que, em razão do aumento significativo do número de ações judiciais de responsabilidade civil, as seguradoras, muitas vezes, têm hesitado em cobrir o prejuízo. Vale lembrar que nos Estados Unidos o risco do desenvolvimento é causa de exoneração de responsabilidade em razão das indenizações altíssimas que os Tribunais impunham às empresas, as seguradoras conseguiram reverter o posicionamento se recusando a pagar as indenizações.

\subsubsection{Do fundo garantidor}

A controvérsia do tema abordado não pode se limitar apenas sobre quem deve arcar com os danos, as empresas e seguradoras, de um lado, e as vítimas, de outro, mas se seria viável a diluição dos danos entre toda a sociedade, por meio de um fundo garantidor.

O direito contemporâneo consubstancia-se na solidariedade social e isso ocorreu diante da perda de importância da culpa e até mesmo com a flexibilização do nexo causal.

Sem dúvida, a solidariedade na reparabilidade dos danos é o próximo caminho a ser trilhado pelo instituto da responsabilidade civil ${ }^{242}$.

O CDC prevê, no artigo 12, a solidariedade, na medida em que todos os fornecedores devem responder solidariamente pelo dano causado.

Para o risco do desenvolvimento, configuraria, talvez, a solução mais justa a criação de um fundo garantidor, para que todas as empresas, de um determinado setor, fossem obrigadas a participar, no caso de ocorrência de eventual dano.

Anderson Schreiber pondera:

“ Melhor orientação, contudo, parece ser a que enxerga a responsabilidade civil de forma mais ampla, como uma técnica de

\footnotetext{
${ }^{242}$ Anderson Schreiber ilustra a questão: "A título meramente ilustrativo, permita-se examinar três meios já em curso de diluição de danos, quais sejam: (i) a ampliação das hipóteses de responsabilidade solidária; (ii) a crescente importância da prevenção e da precaução dos danos; e (iii) o desenvolvimento dos seguros de responsabilidade civil. Uma rápida análise destes fenômenos será útil para compreender os rumos que vêm sendo tomados pela responsabilidade civil contemporânea." (SCHREIBER, Anderson. op. cit., p. 217218).

E adiante complementa: "Parece bastante evidente que, ao difundir o ônus da reparação - e, em última análise, do próprio dano - sobre mais de uma pessoa, a responsabilidade solidária transcende as amarras individualistas da dogmática tradicional da responsabilidade civil e se soma a outros instrumentos mais recentes que, em paralelo às técnicas de responsabilização, vão ganhando espaço, na cultura jurídica contemporânea, como forma de administração dos danos injustos. Neste sentido, mercem particular atenção as técnicas de prevenção e precaução dos danos.” (SCHREIBER, Anderson. op. cit., p. 219).
} 
administração justa (e não apenas eficiente) dos danos produzidos em sociedade - sendo certo que, em um cenário de proliferação de danos anônimos ou casuais, mais justo parece ser a diluição destes danos por toda sociedade ou, ao menos, por um grupo de agentes potencialmente lesivos, que a sua atribuição quase aleatória ao 'culpado' ou 'causador' mais próximo, como tem ocorrido na experiência jurisprudencial de muitos países. Parece restritivo, e excessivamente indiferente à própria evolução histórica do instituto, entender que a responsabilidade civil consiste em noção visceralmente vinculada aos dogmas que a sustentaram a partir da Modernidade, de tal modo que a exigência de diluição dos danos reparáveis seria estranha ao seu âmbito ou incompatível com a sua ontologia. (...)

O que se pretende defender, em síntese, não é uma alteração exterior que implique a passagem de um sistema de responsabilidade a um sistema de solidariedade, mas uma modificação interna à própria responsabilidade civil, que venha a subsitituir uma responsabilidade individual por uma responsabilidade social. Trata-se, em outras palavras, de uma readequação da estrutura histórica do instituto e sua função eminentemente compensatória nos ordenamentos constitucionais da atualidade que reside a fonte dos problemas e incertezas da responsabilidade civil contemporânea." 243

Ugo Carnevali, favorável à excludente de responsabilidade nos riscos do desenvolvimento, defende a criação de um fundo especial, para que ao menos, parcialmente, as vítimas não fiquem desamparadas, mediante contribuições pelos produtores de um mesmo ramo.

Tornaria a reparação das vítimas viável, sem, contudo, onerar demasiadamente apenas um fornecedor, pois, nem sempre é possível identificar que o produto utilizado pelo consumidor foi de determinada empresa e, não de outra, que fabrica o mesmo produto.

A criação de um fundo garantidor ampararia o consumidor, sem transgredir a sua primordial função, a proteção do hipossuficiente.

De forma diversa, Carlo Castronovo se posiciona; para o autor a constituição de um fundo para garantir a reparação das vítimas no caso de riscos do desenvolvimento prejudicaria a prevenção do dano, na medida em que a empresa se sentiria desobrigada de qualquer outra responsabilidade, a não ser o pagamento de sua $\operatorname{cota}^{244}$.Para que isso não ocorra pode se imputar uma maior contribuição às empresas que seriam as maiores responsáveis por eventuais danos oriundos dos defeitos desconhecidos no momento de sua comercialização.

\footnotetext{
${ }^{243}$ SCHREIBER, Anderson. op. cit., p. 226.

${ }^{244}$ Problema e sistema nel danno da prodotti, Milano: Dott. A. Giuffrè Editore, 1979, P. 753. Apud. CALIXTO, Marcelo Junqueira. op. cit., p. 221-222.
} 
Nessa seara, não se pode esquecer que a eventual omissão estatal também pode ensejar a participação do Estado para auxiliar na manutenção desse fundo, na medida em que cabe a órgãos estatais, por exemplo, o registro e a fiscalização dos produtos.

Dessa forma, a constituição de um fundo, talvez seja a solução que seja mais equânime possível. As vítimas serão ressarcidas, de modo a atender aos ditames da atualidade, no tocante à proteção do consumidor. Para as empresas representará uma alternativa, na medida em que não serão diretamente responsabilizadas por danos que não tinham condições de prever.

Na verdade, toda a sociedade se beneficia, uma vez que se colima a coletivização dos riscos. 


\section{CAPÍTULO VI. CONCLUSÃO}

O trabalho procurou demonstrar a importância do estudo do risco do desenvolvimento, na medida em que inúmeros danos decorrentes da utilização de produtos no mercado, dos quais não foi possível detectar a capacidade lesiva.

A discussão é acirrada e ambos os lados, tanto o da responsabilização do fornecedor, quanto o da excludente de responsabilidade, têm motivos consistentes para embasar suas teorias. Por isso a análise deve ser feita com cautela, na medida em que o problema é facilmente identificado, principalmente, na atividade das indústrias farmacêuticas. Com efeito, muitas vezes, ao ser elaborada uma fórmula não foi possível a visualização dos perigos de determinada substância.

A legítima expectativa de segurança deve ser protegida pelo ordenamento jurídico brasileiro, de acordo com os conhecimentos científicos de determinada época da imprevisibilidade do defeito. Com efeito, o critério decisivo é que o produto satisfaça as legítimas expectativas de segurança do público consumidor no momento de sua colocação no mercado.

Além disso, o fornecedor não pode se tornar um "segurador universal" do próprio produto, ao menos, não isoladamente, pois o Estado, muitas vezes participa, nem que seja apenas na autorização da comercialização.

O ordenamento jurídico brasileiro não adotou expressamente a excludente, muito embora alguns doutrinadores entendam que o rol de excludentes de responsabilidade do CDC seja taxativo, o que, não parece ser o mais correto, pois o caso fortuito e a força maior também podem ser elencados como causas de excludente de responsabilidade. Da mesma forma, pode ser considerado o risco do desenvolvimento, o que parece ser o mais razoável, caso contrário, a legítima expectativa do consumidor será supervalorizada.

Diante da omissão na legislação pátria, a controvérsia se mostra viva e longe de ser resolvida da forma mais justa, seja para os consumidores, seja para os fornecedores e até mesmo para a sociedade.

De fato, a comprovação de que o fornecedor não tinha conhecimento do alto grau de nocividade ou periculosidade à saúde ou segurança, de acordo com parâmetros universais, consubstancia, justificadamente, isenção de sua responsabilidade. Essa 
conclusão se obtém da interpretação, a contrario senso, do artigo 10 do CDC que proíbe o fornecedor de colocar no mercado produto ou serviço que sabe, ou deveria saber, apresentar algum grau de nocividade ou periculosidade à saúde ou segurança. Logo, se o fornecedor comprovar que havia impossibilidade objetiva da identificação dos riscos do produto, diante do mais avançado estágio da ciência e da técnica, a exoneração de responsabilidade parece ser o caminho mais correto.

A imprevisibilidade e a impossibilidade de se calcular os danos decorrentes de tais riscos tornaria a carga pesada para o fornecedor e impediria, da mesma forma, a realização de seguro. Seria um desestímulo para o desenvolvimento de novos produtos, ou seja, haveria a paralisação do progresso tecnológico.

Porém, a discussão não se limita na aplicação ou não da excludente de responsabilidade, mas talvez na necessidade de se criar um novo perfil para a responsabilidade civil, voltado para a diluição dos danos, consequentemente, para a solidariedade. Com efeito, a repartição dos riscos parece ser a melhor solução em casos como o da total incognoscibilidade do defeito, principalmente, nos casos de remédios, tendo em vista todos os recursos necessários para sua elaboração.

A fim de se encontrar um equilíbrio na controvérsia, talvez, fosse viável a criação de um fundo garantidor para que todas as empresas fabricantes de determinado produto e, da mesma forma, o Estado, sejam obrigados a contribuir para que, na eventualidade de um dano ocasionado pelo risco do desenvolvimento, as vítimas não ficassem desamparadas. E, assim, não se desrespeitaria o princípio fundamental do CDC, qual seja, a proteção do consumidor, hipossuficiente. De outro lado, nenhum fornecedor seria obrigado a arcar com ônus excessivo, decorrente de dano que não tinha condições de evitar.

É impossível eliminar totalmente os acidentes de consumo, a não ser com a supressão do próprio bem, em algumas hipóteses, ou, em outros casos, com a destruição de uma ou algumas de suas qualidades essenciais.

Não se pode esquecer que a própria vida humana é uma atividade de driblar riscos, é impossível viver sem a assunção daqueles. O direito não tem força para eliminálos totalmente, a sua função é de apenas controlá-los ou minimizá-los. 


\section{REFERÊNCIAS BIBLIOGRÁFICAS}

ALESSI, Renato. Principi di diritto amministrativo. Milano: Giuffrè, 1971. v. 1.

ALMEIDA, Carlos Ferreira de. Os direitos dos consumidores. Coimbra: Almedina, 1982.

ALMEIDA, João Batista de. A proteção jurídica do consumidor. 6. ed. São Paulo: Saraiva, 2008.

ALPA, Guido. Tutela del consumatore e controlli sull'impresa. Bologna: Società Editrice Il Mulino, 1977.

; BESSONE, Mario. La responsabilità del produttore. Milano: Giuffrè, 1987.

ALVIM, Agostinho. Da inexecução das obrigações e suas conseqüências. São Paulo: Saraiva, 1965.

ALVIM, Eduardo Arruda. Responsabilidade civil por fato do produto no Código de Defesa do Consumidor. Belo Horizonte: Del Rey, 1996.

ALVIM, Pedro. O contrato de seguro. 3. ed. Rio de Janeiro: Forense, 2001.

ARAÚJO, Maria Angélica Benetti. Riscos de desenvolvimento à luz das novas tendências da responsabilidade civil. Revista Trimestral de Direito Civil, Rio de Janeiro, v. 31, jul./set. 2007.

ASCENSÃO, José de Oliveira. Revista Trimestral de Direito Civil, Rio de Janeiro, v. 32, out./dez. 2003.

BEAUCHARD, Jean. Droit de la distribuition et de la consommation. Paris: PUF, 1996. (Coll. Thémis).

BENJAMIN, Antônio Herman. Comentários ao Código de Defesa do Consumidor. 3. ed. São Paulo: Ed. Revista dos Tribunais, 2006.

BOWLES, Roger. Diritto e economia. Bologna: Il Mulino, 1985.

CALAIS-AULOY, Jean. Droit de la consommation. 4. ed. Paris: Dalloz, 1996.

CALIXTO, Marcelo Junqueira. A culpa na responsabilidade civil. Rio de Janeiro: Renovar, 2008.

A responsabilidade civil do fornecedor de produtos pelos riscos do desenvolvimento. Rio de Janeiro: Renovar, 2004. 
CANOtilho, J. J. Gomes; MOREIRA, Vital. Constituição da República Portuguesa anotada. 2. ed. Coimbra, 1984. v. 1.

CARVENALI, Ugo. La responsabilitá del produttore. Milano: Giuffrè, 1974.

CASADO, Márcio Mello. Proteção do consumidor de crédito bancário e financeiro. 2. ed. São Paulo: Ed. Revista dos Tribunais, 2006.

CASTRO, Carlos Roberto Siqueira. Função normativa regulatória e o novo princípio da legalidade: o poder normativo das agências reguladoras. Rio de Janeiro: Forense, 2006.

CAVALIERI FILHO, Sergio. Programa de responsabilidade civil. 6. ed. São Paulo: Malheiros, 2006.

CAVES, Richard E.; FRANKEL, Jeffrey A.; JONES, Ronald W. Economia internacional: comércio e transações globais. Tradução Cecília Camargo Bartalotti, Celio Knipel Moreira. São Paulo: Saraiva, 2001.

CHINELlATO, Silmara Juny de Abreu; MORATO, Antonio Carlos. In: NERY, Rosa Maria; DONINI, Rogério (Coords.). Responsabilidade civil: estudos em homenagem ao professor Rui Geraldo Camargo Viana. São Paulo: Ed. Revista dos Tribunais, 2009.

COELHO, Fabio Ulhoa. O empresário e os direitos do consumidor: o cálculo empresarial na interpretação do Código de Defesa do Consumidor. São Paulo: Saraiva, 1994.

COMPARATO, Fabio Konder. O poder de controle na sociedade anônima. São Paulo: Ed. Revista dos Tribunais, 1975. Tese de concurso para provimento do cargo de Professor Titular da Faculdade de Direito da Universidade de São Paulo.

A proteção ao consumidor na Constituição brasileira de 1988. Revista de Direito Mercantil, Industrial, Econômico e Financeiro, São Paulo, v. 29, n. 80, p. 66-75, out./dez. 1990.

CRUZ, Gisela Sampaio da. O problema do nexo causal na responsabilidade civil. Rio de Janeiro: Renovar, 2005.

DE CICCO, Maria Cristina. A pessoa e o mercado. In: TEPEDINO, Gustavo (Org.). Direito civil contemporâneo: novos problemas à luz da legalidade constitucional. Anais do Congresso Internacional de Direito Civil-Constitucional da Cidade do Rio de Janeiro. Atlas, 2008.

DE CUPIS, Adriano. Il danno teoria generale della responsabilità civile. 2. ed. Milano: Giuffrè, 1996. v. 1.

DE LUCCA, Newton. Direito do consumidor: teoria geral da relação jurídica de consumo. 2. ed. São Paulo: Quartier Latin, 2008. 
DENARI, Zelmo et al. Código Brasileiro de Defesa do Consumidor comentado pelos autores do anteprojeto. 8. ed. Rio de Janeiro: Forense Universitária, 2004.

DIAS, José de Aguiar. Da responsabilidade civil. 11. ed. atual. de acordo com o Código Civil de 2002, e aumentada por Rui Berford Dias. Rio de Janeiro: Renovar, 2006.

DINIZ, Maria Helena. Código Civil comentado. Coordenador até a 5. ed. Ricardo Fiuza., 6. ed. rev. e atual., coordenação de Regina Beatriz Tavares da Silva. São Paulo: Saraiva, 2008.

DORNELES, Renato Moreira. A intervenção estatal brasileira nas relações de consumo: estrutura legislativa e fundamentos. Revista de Direito do Consumidor, São Paulo, n. 54, abr./jun. 2004.

DROMI, Roberto. Derecho administrativo. Buenos Aires: Ciudad Argentina, 2001.

DUQUE, Marcelo Schenk. A proteção do consumidor como dever de proteção estatal de hierarquia constitucional. Revista de Direito do Consumidor, São Paulo, n. 70, jul./set. 2009.

EBERLIN, Fernando Büscher von Teschenhausen. O concorrente como consumidor equiparado: proteção ao consumidor contra práticas abusivas por meio do diálogo entre o CDC e as normas concorrenciais. Revista de Direito do Consumidor, São Paulo, ano 17, n. 67, jul./set. 2008.

FERRAZ, Antônio Camargo; MILARÉ, Édis; NERY JÚNIOR, Nelson. Ação civil pública:aspectos sócio-jurídicos de sua imprescindibilidade. São Paulo: Ed. Revista dos Tribunais 2006.

FILOMENO, José Geraldo Brito. Manual de direitos do consumidor. São Paulo: Atlas, 2007.

FORGIONI, Paula. A evolução do direito comercial brasileiro: da mercancia ao mercado. São Paulo: Ed. Revista dos Tribunais, 2009.

FRADA, Manuel Antonio de Castro Portugal Carneiro da. Teoria da confiança $e$ responsabilidade civil. Coimbra: Almedina, 2004.

FREITAS, Juarez. Direitos humanos e democracia. Coordenadores Clèmerson Merlin, Ingo Wolfgang Sarlet e Alexandre Coutinho Pagliarini. Rio de Janeiro: Forense, 2007.

GATES, Bill. A empresa na velocidade do pensamento: com um sistema nervoso digital. Tradução Pedro Maia Soares, Gabriel Tranjan Neto; assessoria técnica Sylvia Meraviglia Crivelli. São Paulo: Companhia das Letras, 1999. 
GIANASI, Anna Luiza de Castro. As relações de consumo e o princípio da transparência: uma proposta de integração jurídico-normativa para o Mercosul. Revista de Direito do Consumidor, São Paulo, ano 15, abr./jun. 2006.

GODOY, Claudio Luiz Bueno de. Responsabilidade civil pelo risco da atividade: uma cláusula geral no Código Civil de 2002. São Paulo: Saraiva, 2009.

GOMES, Orlando. Contratos. 11. ed. Rio de Janeiro: Forense, 1986.

GRAU, Eros. Contribuição para a interpretação e a crítica da ordem econômica na Constituição de 1988. 1990. Tese (Titular) - Faculdade de Direito, Universidade de São Paulo, São Paulo, 1990.

Interpretando o Código de Defesa do Consumidor: algumas notas. Revista de Direito do Consumidor, São Paulo, n. 5, p. 183-189, jan./mar. 1993.

GRINOVER, Ada Pelegrini et. al. Código Brasileiro de Defesa do Consumidor Comentados pelos autores do anteprojeto, $6^{\mathbf{a}}$ edição, Rio de Janeiro: Forense Universitária, 2000 .

GUIMARÃES, Paulo Jorge Scartezzini. Vícios do produto e do serviço por qualidade, quantidade e insegurança: cumprimento imperfeito do contrato. 2. ed. rev. atual. e ampl. São Paulo: Ed. Revista dos Tribunais, 2007.

HENKE, Wilhelm. Das subjektive öffentliche Recht. Tübingen, 1968.

HERNANDEZ, Carlos A; FRUSTAGLI, Sandra A. Primeras consideraciones sobre los alcances de la reforma a la Ley de Defensa del Consumidor, con especial referencia a la materia contractual. Revista de Direito do Consumidor, São Paulo, v. 17, n. 67, p. 243-265, jul./set. 2008.

HIRATA, Mario Hiroyuki; MANCINI FILHO, Jorge. Manual de biossegurança. Barueri: Manole, 2008.

HIRONAKA, Giselda Maria Fernandes. Responsabilidade pressuposta. Belo Horizonte: Del Rey, 2005.

HORVATH JÚNIOR, Miguel. Uma análise da autonomia privada e o fenômeno da globalização e seus efeitos no direito constitucional e no direito internacional privado. In: LOTUFO, Renan (Coord.). Direito civil constitucional: cadernos 1. São Paulo: Max Limonad, 1999.

IRTI, Natalino. L'età della decodificazione. Milano: Giuffrè, 1976.

JUSTEN FILHO, Marçal. Curso de direito administrativo. São Paulo: Saraiva, 2005. 
JUSTEN FILHO, Marçal. O direito das agências reguladoras independentes. São Paulo: Dialética, 2002.

KELSEN, Hans. Teoria pura do direito. Tradução francesa da 2. ed. por Ch. Einsenmann, Paris: Dalloz, 1962.

LIMA, Alvino. Culpa e risco. 2. ed. rev.e atual. pelo Prof.Ovídio Rocha Barros Sandoval. São Paulo: Ed. Revista dos Tribunais, 1998.

LOBO, Paulo Luiz Netto. A informação como direito fundamental do consumidor. Revista de Direito do Consumidor, São Paulo, n. 37, p. 59-76, jan./mar. 2001.

LOPEZ, Teresa Ancona. Nexo causal e produtos potencialmente nocivos: a experiência brasileira do tabaco. São Paulo: Quartier Latin, 2008.

LOTUFO, Renan. Direito civil constitucional. São Paulo: Max. Limonad, 1999. (Cadernos $1)$.

MALUF, Carlos Alberto Dabus. Responsabilidade civil e sua repercussão nos tribunais. Coord. Regina Beatriz Tavares da Silva. São Paulo: Saraiva, 2008.

MANTOUX, Paul. A revolução industrial no século XVIII. São Paulo: Unesp, 1985.

MARCONDES, Sylvio. Da atividade negocial: empresários e sociedades Problemas de Direito Mercantil, Max Limonad.

Problemas de direito mercantil. São Paulo: Max Limonad.

MARQUES, Claudia Lima. Contratos no Código de Defesa do Consumidor: o novo regime das relações contratuais. 4. ed. São Paulo: Ed. Revista dos Tribunais, 2002.

Contratos no Código de Defesa do Consumidor: o novo regime das relações contratuais. 5. ed. São Paulo: Ed. Revista dos Tribunais, 2005.

; BENJAMIN, Antônio Herman; BESSA, Leonardo Roscoe. Manual de direito do consumidor. São Paulo: Ed. Revista dos Tribunais, 2008.

; ___ MIRAGEM, Bruno. Comentários ao Código de Defesa do Consumidor.

2. ed. São Paulo: Ed. Revista dos Tribunais, 2006.

MELLO, Celso Antônio Bandeira de. O conteúdo jurídico do princípio da igualdade. 3. ed. São Paulo: Malheiros, 2006.

. Curso de direito administrativo. 19. ed. São Paulo: Malheiros, 2005.

MELLO, Heloisa Carpena Vieira de. Responsabilidade civil no Código de Defesa do Consumidor. Revista de Direito do Consumidor, São Paulo, n. 28, p. 59-67, out./dez. 1998. 
MENDES, Gilmar Ferreira. Direitos fundamentais: eficácia das garantias constitucionais nas relações privadas: analise da Jurisprudência da Corte Constitucional Alemã. Cadernos de Direito Constitucional e Ciência Política, São Paulo, v. 7, n. 27, p. 33-44, abr./jun. 1999.

MERLIN, Clèmerson; SARLET, Ingo Wolfgang; PAGLIARINI, Alexandre Coutinho (Coords). Direitos humanos e democracia. Rio de Janeiro: Forense, 2007.

MONTEIRO, Antonio Pinto. RTDC: Revista Trimestral de Direito Civil, Rio de Janeiro, v. 30, abr./jun. 2007.

MONTESQUIEU, Charles de Secondat, Baron de. O espírito das leis: as formas de governo, a federação, a divisão dos poderes. Introdução, tradução e notas de Pedro Vieira Mota. 9. ed. São Paulo: Saraiva, 2008.

MORAES, Alexandre. Direito constitucional. 15. ed. São Paulo: Altas, 2004.

Direitos humanos fundamentais: teoria geral, comentários aos arts. $1^{\circ}$ a $5^{\circ}$ da Constituição da República Federativa do Brasil, doutrina e jurisprudência. 7. ed. São Paulo: Atlas, 2006.

MORAES, Maria Celina Bodin de Danos à pessoa humana: uma leitura civilconstitucional dos danos morais. Rio de Janeiro: Renovar, 2003.

. Princípios do direito civil contemporâneo. Rio de Janeiro: Renovar, 2006.

MORALES, Mirta. Un estudio comparativo de la protección legislativa del consumidor en el ambito interno de los paises del Mercosur. Rio de Janeiro: Renovar, 2006.

NASCIMENTO, Tupinambá. Comentários à Constituição Federal. Porto Alegre: Livr. do Advogado, 1997.

OLIVEIRA JUNIOR, José Alcebíades de. Direito ambiental e direito do consumidor: polêmica dos transgênicos. Revista de Direito do Consumidor, São Paulo, ano 17, n. 66, abr./jun. 2008.

PEREIRA, Caio Mario da Silva. Responsabilidade civil. Rio de Janeiro: Forense, 1999.

PERELMAN, Chaim. Ética e direito. Lisboa: Instituto Piaget, 1990.

PISANO, Gary P. Science business: the promisse, the reality, and the future of biotech. Boston, Massachusetts: Harvard Business School Press, 2006.

PUSCHEL, Flavia Portella. A responsabilidade por fato do produto no CDC: acidentes de consumo. São Paulo: Quartier Latin, 2006.

REALE, Miguel. Lições preliminares de direito. 22. ed. São Paulo: Saraiva, 1995. 
RIPERT, Georges. A regra moral nas obrigações civis. Campinas: Bookseller, 2000.

RIVERO, Jean. Direito administrativo. Coimbra: Almedina, 1981.

SARLET, Ingo. A eficácia do direito fundamental à segurança jurídica: dignidade da pessoa humana, direitos fundamentais e proibição de retrocesso social no direito constitucional brasileiro. In: ROCHA, Carmen Lucia Antunes. et al. Constituição e segurança jurídica: direito adquirido, ato jurídico perfeito e coisa julgada. $2^{a}$ edição. São Paulo: Ed. Forum.

SCARTEZZINI, Jorge Tadeo Goffi Flaquer. Suspensão de segurança. São Paulo: Ed. Revista dos Tribunais, 2010.

SCHREIBER, Anderson. Flexibilização do nexo causal em relações de consumo. In: MARTINS, Guilherme Magalhães (Coord.). Temas de direito do consumidor. Rio de Janeiro: Lúmen Juris, 2010.

SCHREIBER, Anderson. Novas tendências da responsabilidade civil brasileira. RTDC: Revista Trimestral de Direito Civil, Rio de Janeiro, v. 6, n. 22, p. 45-69, abr./jun. 2005.

. Novos paradigmas da responsabilidade civil: da erosão dos filtros da reparação à diluição dos danos. São Paulo: Atlas, 2007.

SIDOU, J. M. Othon. Proteção ao consumidor. Rio de Janeiro: Forense, 1977.

SILVA, Ivan de Oliveira. Curso de direito do seguro. São Paulo: Saraiva, 2008.

SILVA, João Calvão da. Compra e venda de coisas defeituosas: conformidade e segurança. Coimbra: Almedina, 2002.

Responsabilidade civil do produtor. Coimbra: Almedina, 1999.

SILVA, José Afonso da. Curso de direito constitucional positivo. 6. ed. São Paulo: Ed. Revista dos Tribunais, 1991.

SILVA, Wilson Melo da. Responsabilidade sem culpa. São Paulo: Saraiva, 1974.

SOUZA, James Marins de. Risco de desenvolvimento e tipologia das imperfeições dos produtos. Revista de Direito do Consumidor, São Paulo, n. 6, p. 118-133, abr./jun. 1993.

. Risco de desenvolvimento e tipologia das imperfeições dos produtos. Revista de Direito do Consumidor, São Paulo, ano 17, n. 67, jul./set. 2008.

SOUZA, Washington Peluso Albino de Souza. Primeiras linhas de direito econômico. 5. ed. São Paulo: LTr, 2003. 
SOWELL, Thomas. Basic economics: a common sense guide to the economy. 3. ed. New York: Basic Books, 2007.

TÁCITO, Caio. Temas de direito público: (estudos e pareceres). Rio de Janeiro: Renovar, 1997.

TADEU, Silney Alves. As dimensões do consumo: reflexões para uma teoria compreensiva. Revista de Direito do Consumidor, São Paulo, n. 56, out./dez. 2005.

TEPEDINO, Gustavo. O Código Civil os chamados microssistemas e a Constituição: premissas para uma reforma legislativa. In: ___. Problemas de direito civilconstitucional. Rio de Janeiro: Renovar, 2000.

O futuro da responsabilidade civil. In: Temas de direito civil. Rio de Janeiro: Renovar, 2009. t. 3.

A responsabilidade por acidentes de consumo na ótica civil-constitucional. In: . Temas de direito civil. 2. ed. Rio de Janeiro: Renovar, 2001.

. Temas de direito civil. Rio de Janeiro: Renovar, 2009. t. 3.

TOMAZETTE, Marlon. Direito societário. São Paulo: Juarez de Oliveira, 2004.

TRENTINI, Flávia. Fauna, políticas públicas e instrumentos legais = Wildlife protection: policy and legal instruments. Organizado por Antonio Herman Benjamin. São Paulo: Instituto O Direito por um Planeta Verde, 2004.

UMBREIT, Myron; HUNT, Elgin; KINTER, Charles. Economia: princípios e problemas. 3. ed. Rio de Janeiro: Fundo de Cultura, 1957.

ZANCHET, Marília. A nova força obrigatória dos contratos e o princípio da confiança no ordenamento jurídico brasileiro: análise comparada entre o CDC e o CC/2002. Revista de Direito do Consumidor, São Paulo, n. 58, abr./jun. 2006. 